\title{
The Regulatory Environment and SMMEs. Evidence from South African Firm Level Data
}

\author{
Neil Rankin \\ School of Economics and Business Sciences \\ University of the Witwatersrand \\ rankinn@sebs.wits.ac.za
}




\section{Acknowledgement}

This Working Paper is one in a series emanating from the SMME project, within the Employment Promotion Programme, which is aimed at Understanding the Regulatory Environment for Small Business in South Africa. The DPRU are the Programme Managers of this DFID funded project whose goal is to promote an enabling environment for employment creation in South Africa, and to contribute to the Government's goal of reducing unemployment.

Development Policy Research Unit Tel: +27 216505705

Fax: +27216505711
Information about our Working Papers and other published titles are available on our website at: http://www.commerce.uct.ac.za/dprul 


\section{Abstract}

This paper investigates the impact of government regulation on firms in general, and SMMEs in particular, using four independent cross-sectional surveys. It specifically examines: labour regulations and their relationship with employment and investment; trade regulations; permits and licences for businesses; visa regulations; the predictability of regulatory application; and the costs of regulation. It also investigates the ways firms respond to regulations. Labour market regulations are the most often mentioned regulatory constraint to business and are mentioned as often as obstacles such as the availability of skilled workers, crime and theft, and macroeconomic instability. There is evidence that these regulations constrain firm growth, particularly among smaller firms. The unskilled in smaller firms are most likely to lose their jobs due to these regulations. Labour regulations are not the only type of regulations that have a disproportional effect on smaller firms. The cost of complying with tax regulations, in terms of the cost per worker, is much larger for smaller firms. Smaller firms are also more likely to identify tariff barriers as too high. A common finding throughout the paper is that it is the administrative burden and time costs associated with regulations rather than the direct monetary costs that are the most costly.

Government regulation comes in many forms, such as tax regulation, labour regulation and regulations concerning the import and export of goods. These regulations have both costs and benefits, which government must balance. This paper uses data gathered from a number of South African firm-level surveys to investigate how government regulations impact on firms. A particular focus is on how the impact of regulations differs by firm size.

Regulation is a broad area that impacts on firms in many different ways. This paper does not try to investigate all the different aspects of regulation, but instead focuses on those regulations firms mention as the most onerous. Furthermore, because the information is drawn from existing firm-level surveys the types of questions that can be investigated are constrained by the questions asked in these surveys. In many cases firms are asked about the perceived impact of regulations. Of course, perceptions matter, especially if managers base decisions on whether to invest or change employment on these perceptions, but where possible, we have attempted to examine the link between regulations and measurable firm responses. 
The paper starts off by providing an overview of the firm-level datasets used. Where possible, it reports on the sector and size breakdown and compare the size distributions of firms in each of the samples.

In Section 2 we examine whether firms perceive government regulation to be a serious obstacle to business and whether regulation is perceived to be as serious an obstacle as other obstacles firms face. This places regulation in context.

The third section of the paper investigates the link between government regulation and investment. Investment is important because it allows firms to increase production and scale, reduce costs and acts as a conduit for technical and productivity improvements. In competitive and dynamic markets firms that do not invest risk losing market share.

In Section 4 of the paper the relationship between regulation and employment is examined. In particular, the impact of the labour market regulations introduced in the mid-1990s is evaluated. We investigate the impact of these regulations on firm growth and whether they affect certain classes of workers disproportionately. In this section we also look at whether firms perceive any benefits to labour market regulation.

The fifth section investigates the impact of trade regulation on SMMEs. The sixth section considers regulations concerned with the granting of business licences and permits. Section 7 examines other aspects of regulations, such as visa regulations and the predictability of regulations.

The eighth section of this paper deals with the specific cost of regulation to the firm. This section specifically examines the staff time costs of complying with regulations and the costs of outside advisors and consultants.

The last section concludes. 


\section{Table of Contents}

1. Data Sources.............................................

2. Government Regulation Compared to Other Constraints................................9

2.1 How does Government Regulation Compare to other Obstacles to Doing Business?.........................................................................

2.2 What are the Major Obstacles Constraining the Expansion of Firms? ...................................................................................13

2.3 Are Certain Types of Firms more likely to Report Certain Obstacles?.

3. Government Regulation and Investment..................................................18

3.1 Obstacles Discouraging Investment............................................18

3.2 Are Certain Types of Firms more likely to Report Certain Types of Obstacles to Investment?..........................................................21

3.3 Is the Propensity and Amount Invested Related to Reported

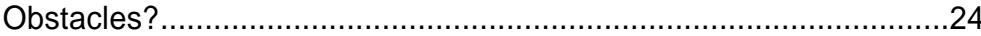

3.4 The Type of Investment and Perceived Obstacles.........................27

4. Labour Regulations and Employment. .30

4.1 Do Firms Perceive the Labour Laws as an Obstacle to Hiring New Employees? 30

4.2 How do the Effects of Labour Regulation on Employment Compare to the Effects of Other Factors?..........................................31

4.3. How do Firms Respond to Labour Regulations?.................................34

4.4 Do Labour Regulations Affect Firm Growth?...................................36

4.5 Which Parts of theLabourRregulations are Most Onerous to Firms? .................................................................................. 41

4.6 Do firms perceive any benefits to the labour regulations? ................44

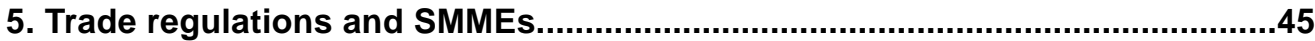

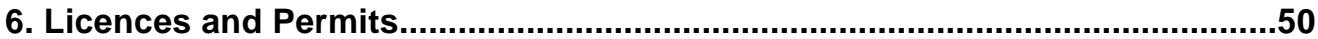

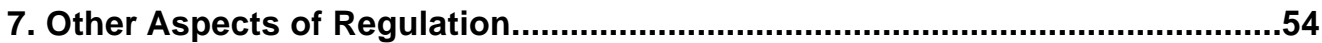

7.1 Immigration Regulations and Hiring Expatriate Staff......................54

7.2 The Consistency, Predictability and Application of Regulations...........55

7.3 Which Government Departments have the most Cumbersome

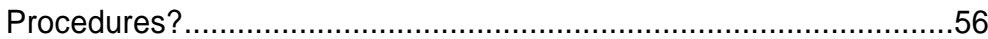

7.4 Time in Meetings about Regulations.........................................58 


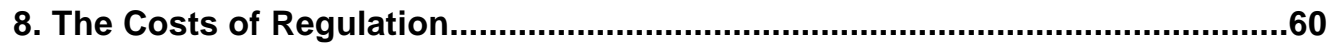

8.1 Regulatory Costs......................................................................60

8.2 What Types of Firms have Experienced Changes in Regulation

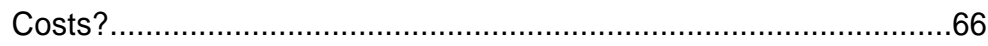

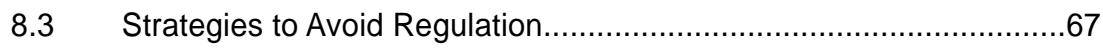

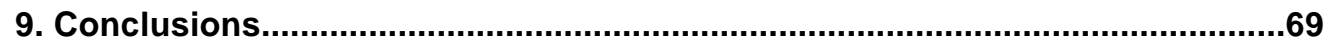

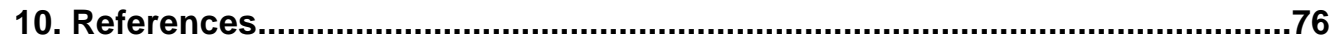




\section{Data Sources}

The data used in this paper comes from four independent sources. ${ }^{1}$ The first is a World Bank/Greater Johannesburg Metropolitan Council survey undertaken in the Greater Johannesburg Metropolitan Area in 1999 (hereafter referred to as the WB/GJMC survey). This survey interviewed manufacturing firms with more than 50 employees. The second survey is the National Enterprise Survey (NES) also undertaken in 1999. This survey was national in scope, covered both the manufacturing and services sectors and was not confined to a specific size group. The third source of data is the survey undertaken by the Small Business Project (SBP) for their "Counting the Cost of Red Tape for business in South Africa" report. This survey was undertaken in 2004 and covers a wide spectrum of firms in a number of sectors. The last source of data is the World Bank's Investment Climate Assessment (ICA). This survey was national in scope and surveyed firms in the manufacturing sector. It was undertaken in 2003.

Although a number of firm-level surveys have been carried out in South Africa, all have been done on an ad hoc basis. None have been repeated, so there is no panel data available, which means that it is difficult to monitor firm behaviour over time. In all these surveys the time dimension comes from recall questions. Furthermore, many of the firm surveys undertaken in South Africa are badly designed for quantitative analysis and lack the basic ingredients to estimate a production function.

Table 1 provides descriptive statistics for total employment and the natural logarithm of total employment ${ }^{2}$ for the ICA, WB/GJMA and NES surveys.

1 A fifth source of data would be the Ekhuruleni Manufacturing survey undertaken by the CSID at Wits University. This dataset is limited and does not ask many questions about regulations. It does ask firms to rate the seriousness of certain obstacles to business. These rankings are very similar to the results presented in Section 2.

2 The natural logarithm is used to convert the data into a distribution that more closely resembles the normal distribution. A second reason for using the natural logarithm is that it reduces the relative magnitude of large outlying observations and thus the effect these have on the mean. An example helps to clarify this. The mean of employment in the ICA survey is 342.62 and the mean of In(employment) is 4.67. If the mean of In(employment) is converted back to actual employment numbers (by raising $e$ to the power of 4.67) this converts to a value of 106.7 employees. This suggests that there are a number of large firms that are responsible for raising the mean value. This is confirmed if the median value is used. Median employment is 90 and the employment value obtained from converting the log of employment is 90.02 . 
Table 1: Descriptive Statistics for Employment for the ICA, WB/GJMA and NES Surveys

\begin{tabular}{|l|c|c|c|c|c|c|}
\hline & \multicolumn{2}{|c|}{ ICA (2002) } & \multicolumn{2}{c|}{ WB/GJMA (1998) } & \multicolumn{2}{c|}{ NES (1998) } \\
\hline & Employment & $\operatorname{In}(\mathrm{emp})$ & Employment & $\operatorname{In}(\mathrm{emp})$ & Employment & $\operatorname{In}(\mathrm{emp})$ \\
\hline Mean & 342.62 & 4.67 & 246.50 & 4.91 & 353.95 & 3.67 \\
\hline Median & 90 & 4.5 & 110 & 4.70 & 27.75 & 3.32 \\
\hline Std dev & 1132.74 & 1.36 & 642.64 & 0.88 & 2142.44 & 1.62 \\
\hline $\mathrm{N}$ & 594 & 594 & 328 & 328 & 1410 & 1410 \\
\hline Min & 5 & 1.61 & 40 & 3.69 & 1 & 0 \\
\hline Max & 20153.50 & 9.91 & 9318 & 9.14 & 43000 & 10.67 \\
\hline
\end{tabular}

These descriptive statistics illustrate the different sample properties. The WB/GJMA survey has the largest median firm and the least dispersion of firm size. This is because it interviewed only firms larger than 50 employees. ${ }^{3}$ The NES interviewed the most number of firms and it covered both the manufacturing and services sectors. It has the widest size dispersion but the typical firm, as measured by the median, is the smallest of these three surveys. The ICA survey interviewed almost 600 firms and has a typical firm of 90 employees. The variation in size among the firms interviewed is larger than the WB/GJMA sample but smaller than the NES.

Figures 1-3 indicate the size distribution of firms in these three surveys.

3 A number of firms smaller than 50 employees were interviewed. These firms were larger than 50 employees in the list used to draw the sample but had subsequently decreased in size. 
Figure 1: The Size Distribution of Firms in the ICA Survey

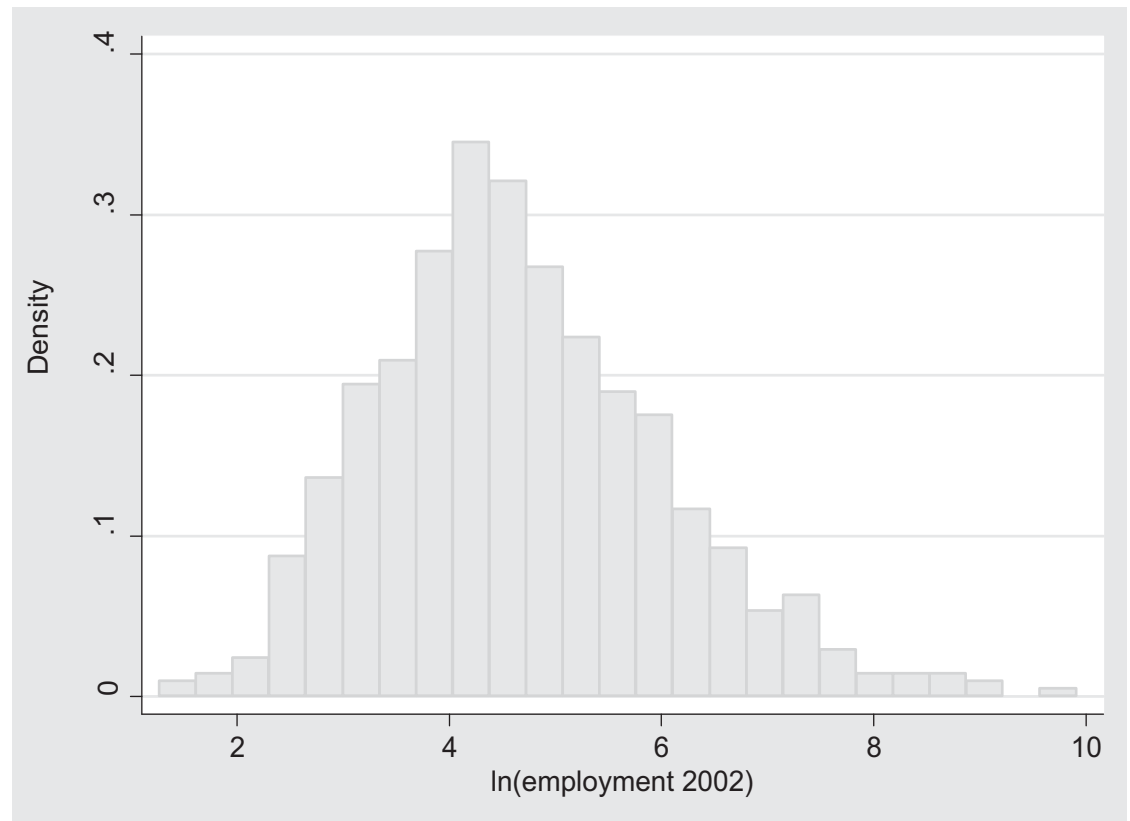

Figure 2: The Size Distribution of Firms in the WB/GJMA Survey

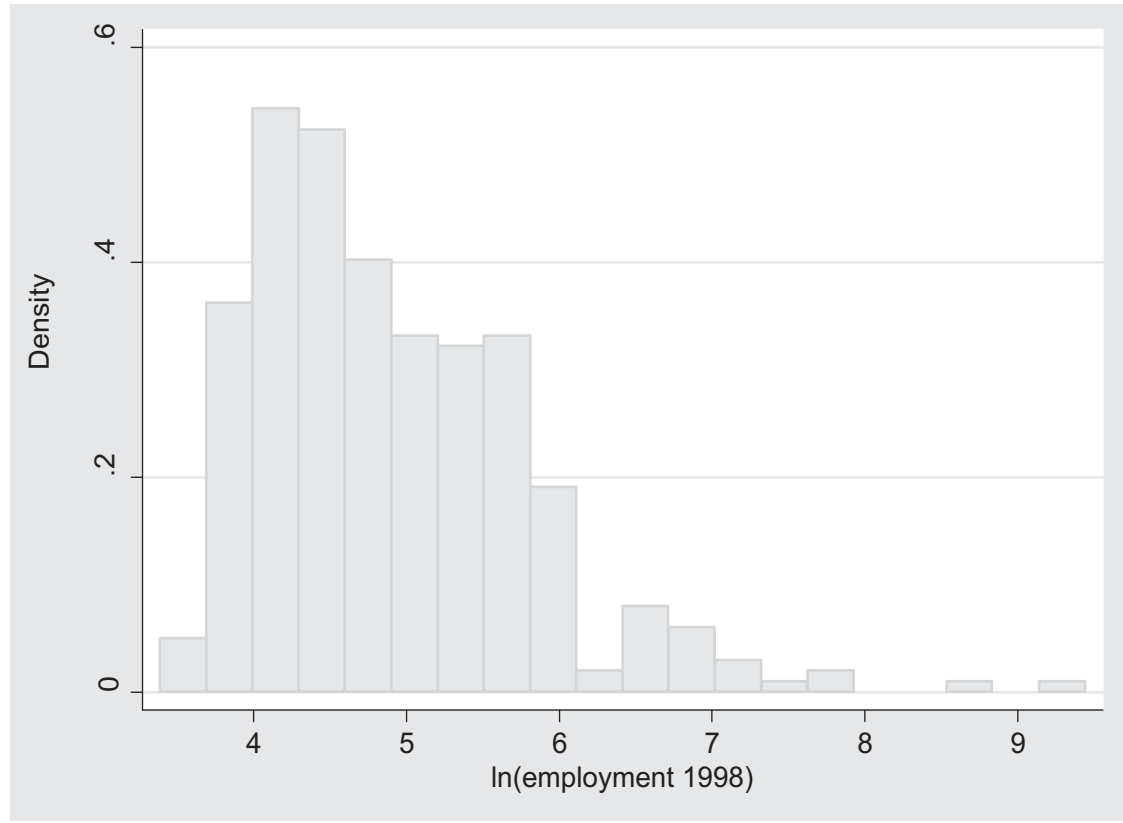


Figure 3: The Size Distribution of Firms in the NES Survey

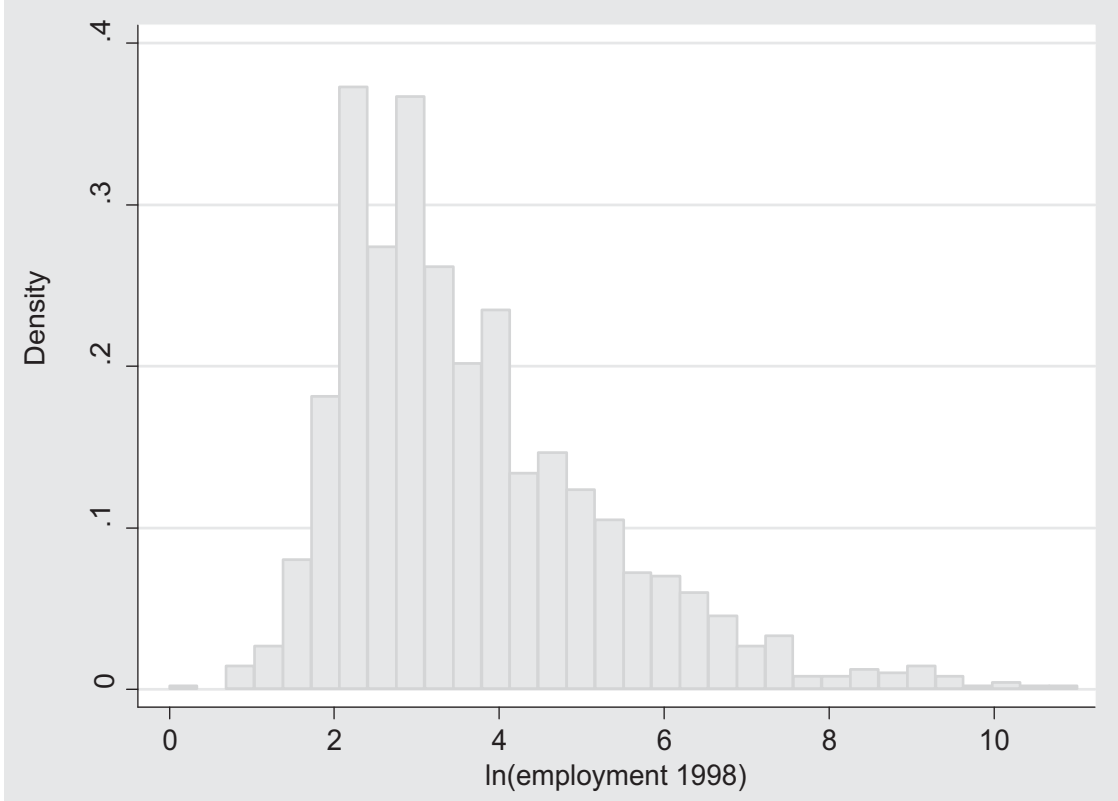

The size breakdown of firms by province in the ICA survey is given in Table 2. As the table illustrates the majority of firms are from Gauteng, followed by the Western Cape. Large firms, employing 200 or more people, are the most common of size categories.

Table 2: Number of Firms in the ICA survey, by Size and Province

\begin{tabular}{|l|c|c|c|c|c|}
\hline & \multicolumn{5}{|c|}{ Province } \\
\hline $\begin{array}{l}\text { Size } \\
\text { category }\end{array}$ & Gauteng & $\begin{array}{c}\text { KwaZulu } \\
\text { Natal }\end{array}$ & $\begin{array}{c}\text { Western } \\
\text { Cape }\end{array}$ & $\begin{array}{c}\text { Eastern } \\
\text { Cape }\end{array}$ & Total \\
\hline$<50$ & 81 & 14 & 60 & 6 & $\mathbf{1 6 1}$ \\
\hline $50-99$ & 109 & 11 & 21 & 6 & $\mathbf{1 4 7}$ \\
\hline $100-199$ & 76 & 14 & 15 & 9 & $\mathbf{1 1 4}$ \\
\hline $200 \mathrm{~d}$ & 106 & 20 & 33 & 13 & $\mathbf{1 7 2}$ \\
\hline Total & $\mathbf{3 7 2}$ & $\mathbf{5 9}$ & $\mathbf{1 2 9}$ & $\mathbf{3 4}$ & $\mathbf{5 9 4}$ \\
\hline
\end{tabular}

The sector breakdown of firms in the WB/GJMA, NES and SBP surveys are given in Tables 3-5. 
Table 3: Number of Firms in the WB/GJMA Survey, by Size and Sector

\begin{tabular}{|l|c|c|c|c|}
\hline & \multicolumn{3}{|c|}{ Size Category } & \\
\hline Sector & $40-99$ & $100-199$ & $200+$ & Total \\
\hline Chemical & 21 & 14 & 13 & $\mathbf{4 8}$ \\
\hline Electrical & 29 & 9 & 18 & $\mathbf{5 6}$ \\
\hline Food & 9 & 6 & 11 & $\mathbf{2 6}$ \\
\hline Iron \& steel & 26 & 11 & 19 & $\mathbf{5 6}$ \\
\hline Metal products & 29 & 18 & 10 & $\mathbf{5 7}$ \\
\hline Paper \& furniture & 12 & 12 & 10 & $\mathbf{3 4}$ \\
\hline Textiles & 6 & 4 & 4 & $\mathbf{1 4}$ \\
\hline Auto & 14 & 7 & 13 & $\mathbf{3 4}$ \\
\hline Total & $\mathbf{1 4 6}$ & $\mathbf{8 1}$ & $\mathbf{9 8}$ & $\mathbf{3 2 5}$ \\
\hline
\end{tabular}

The largest number of firms in the WB/GJMA sample is in the 40-99 size group and the largest sectors are electrical, iron and steel and metal products. The smallest sector is textiles. Many textile firms are based in the Western Cape and thus the Johannesburgonly sample has a smaller proportion of textile firms than a sample that would include other metropolitan areas. This sample also contains more large firms than the national population. This is because it only sampled firms with more than 50 employees and also because Johannesburg, the major industrial centre in South Africa, is likely to have more very large firms than other parts of the country. However, since Johannesburg is the industrial heartland of the country, this survey is representative of firms that produce a large proportion of the industrial output of the country. 
Table 4: Number of Firms in the NES Survey, by Size and Sector

\begin{tabular}{|c|c|c|c|c|c|c|}
\hline & \multicolumn{5}{|c|}{ Size Category } & \multirow[b]{2}{*}{ Total } \\
\hline Sector & $<10$ & $10-49$ & $50-99$ & $100-199$ & $200+$ & \\
\hline Food & 5 & 44 & 17 & 12 & 21 & 99 \\
\hline Wood & 13 & 62 & 14 & 7 & 20 & 116 \\
\hline Chemicals & 17 & 59 & 15 & 13 & 15 & 119 \\
\hline Auto & 7 & 45 & 12 & 7 & 22 & 93 \\
\hline Textiles & 18 & 48 & 18 & 14 & 17 & 115 \\
\hline Metal & 19 & 37 & 24 & 9 & 12 & 101 \\
\hline Furniture & 8 & 46 & 8 & 11 & 12 & 85 \\
\hline Electrical & 22 & 46 & 13 & 10 & 18 & 109 \\
\hline Printing & 16 & 44 & 8 & 9 & 15 & 92 \\
\hline Finance & 26 & 43 & 8 & 10 & 23 & 110 \\
\hline IT & 25 & 46 & 14 & 6 & 11 & 102 \\
\hline Tourism & 17 & 52 & 9 & 8 & 14 & 100 \\
\hline Retail & 48 & 84 & 9 & 10 & 15 & 166 \\
\hline $\begin{array}{l}\text { Total } \\
\text { manufacturing }\end{array}$ & 125 & 431 & 129 & 92 & 152 & 929 \\
\hline Total services & 116 & 225 & 40 & 34 & 63 & 478 \\
\hline Total & 241 & 656 & 169 & 126 & 215 & 1,407 \\
\hline
\end{tabular}

The largest proportion of firms in the NES sample are in the 10-49 employee size group. The number of firms in this size group is more than double that of the next two largest groups - less than 10 employees and more than 200 employees. The size distribution of the firms in the NES survey is illustrative of a phenomenon common in developing countries called the "missing middle". The size distribution of firms in many developing countries is often characterised by many small and very large firms but very few firms in the middle of the distribution. An explanation often given for this is that firms remain small in order to avoid regulation (see Tybout, 2000, for an explanation).

Firms in the service sector are about half the number of firms in the manufacturing sector. There are relatively more smaller firms in the service sector than the manufacturing sector but the missing middle is present in both sectors. Among the individual sub-sectors the retail sector is largest and the furniture sector the smallest. The number of firms in individual sub-sectors varies between 85 and 166 . 
Table 5: Number of firms in the SBP survey, by size and sector

\begin{tabular}{|c|c|c|c|c|c|c|c|c|}
\hline \multirow[b]{2}{*}{ Sector } & \multicolumn{7}{|c|}{ Size Category } & \multirow[b]{2}{*}{ Total } \\
\hline & $<5$ & $5-9$ & $10-49$ & $50-99$ & $\begin{array}{c}100- \\
199\end{array}$ & $\begin{array}{l}200- \\
499\end{array}$ & $500<$ & \\
\hline $\begin{array}{l}\text { Agriculture, } \\
\text { hunting etc. }\end{array}$ & 4 & 3 & 6 & 2 & 3 & 0 & 0 & 18 \\
\hline $\begin{array}{l}\text { Mining and } \\
\text { quarrying }\end{array}$ & 0 & 0 & 4 & 0 & 1 & 2 & 0 & 7 \\
\hline Manufacturing & 45 & 67 & 115 & 26 & 11 & 10 & 18 & 292 \\
\hline Electricity, gas & 0 & 1 & 1 & 1 & 0 & 0 & 0 & 3 \\
\hline Construction & 16 & 17 & 42 & 8 & 2 & 4 & 0 & 89 \\
\hline $\begin{array}{l}\text { Trade, vehicle } \\
\text { sales, hotels }\end{array}$ & 146 & 126 & 152 & 18 & 5 & 6 & 6 & 459 \\
\hline $\begin{array}{l}\text { Transport and } \\
\text { storage }\end{array}$ & 4 & 3 & 18 & 4 & 2 & 2 & 3 & 36 \\
\hline $\begin{array}{l}\text { Financial, } \\
\text { insurance }\end{array}$ & 94 & 75 & 75 & 22 & 7 & 4 & 9 & 286 \\
\hline $\begin{array}{l}\text { Community , social } \\
\text { \& personal } \\
\text { services }\end{array}$ & 43 & 16 & 15 & 1 & 1 & 0 & 1 & 77 \\
\hline Tourism & 7 & 8 & 14 & 4 & 2 & 0 & 2 & 37 \\
\hline Total & 359 & 316 & 442 & 86 & 34 & 28 & 39 & 1,304 \\
\hline
\end{tabular}

As table 5 illustrates, the trade, manufacturing and financial sectors make up the majority of the SBP sample. In terms of size categories the 10-49 employee category contains the most firms, followed by the $<5$ category. Firms with more than 100 employees make up less than 10 per cent of the sample.

The four surveys used in this paper differ in terms of coverage, both geographically and in terms of size, the questions asked and the time period in which they were taken. This is both a strength and weakness - the different surveys can be used to explore different aspects of the relationship between regulation and SMMEs, but it is difficult in some cases to make comparisons between surveys.

Of the four, the SBP and the ICA are the most recent. The SBP survey was designed to specifically examine the costs of regulation on business. An in depth analysis of the data is provided in the SBP publication "Counting the Cost of Red Tape for business in South Africa." Since it had a very specific goal, this survey only asked broad questions on output and employment and no specific questions on inputs and the capital stock. This means that it is impossible to examine issues of efficiency and control for firm specific characteristics using this survey. However, this survey is still useful.

The ICA survey was undertaken in 2003 and is national in scope. It covers the manufacturing sector and was designed to investigate questions of the nature posed in this paper. The South African ICA survey is part of a broader project where surveys of 
a similar nature were administered in a number of other countries. This enables crosscountry comparisons to be made. However, even though all these questionnaires have a core group of questions, they have been individually tailored to ask questions particularly relevant to each country.

The WB/GJMA and NES surveys both collected data for 1998. Although this is now seven years ago, there is value in examining these surveys. There are a number of reasons why these surveys are useful. Firstly, they capture data from a period where important regulations, such as the labour market regulations and tariffs, were changed. Secondly, in questions that are comparable across time, they allow us to investigate whether there have been changes. Thirdly, they ask questions which have not been asked subsequently. This provides insight into how South African firms behave. Fourthly, the WB/GJMA survey asks for recall data on firm growth. This allows us to examine firm behaviour over time.

All the surveys ask both qualitative, such as firms' perceptions of obstacles, and quantitative, such as firm size or output, questions. An issue often raised when discussing the impact of regulation is the distinction between the perceived and actual effect. With cross-sectional survey data it is difficult to disentangle these two effects as we cannot monitor how perceptions and outcomes change over time. However, where possible, we have tried to use quantitative data to investigate qualitative answers. Thus, for example, when investigating perceived obstacles we have investigated whether factors such as firm size, efficiency, ownership, sector and other observable firm characteristics affect firms' answers. We are thus able to investigate whether there are any systematic factors determining firm responses.

The second point that is important to make is that perceptions do matter. Thus, if a manager perceives a regulation as a constraint to firm growth, the manager is unlikely to expand the business as long as that regulation is perceived to be binding. The challenge to government is not only to reduce regulations that may hamper firm growth, but also change perceptions. Of course, the benefits that may come from changing regulations need to be compared with the potential costs. 


\section{Government Regulation Compared to Other Constraints}

We begin our analysis of the impacts of government regulation by placing these in perspective. To do this we compare the perceived severity of various government regulations to the perceived severity of other obstacles to business, such as the availability of skills, crime and tax rates.

There are three sub-sections in this section. The first use data from the ICA and WB/GJMC survey to investigate whether different types of government regulations are perceived by firms to be problems of the same magnitude as, for example, crime and theft and the cost of capital/credit. The second uses data from the SBP survey to investigate whether firms perceive government regulations to be an important constraint to expansion relative to other constraints they may face. The third sub-section examines whether certain types of firms are more likely to report certain types of obstacles. In this sub-section we are able to investigate whether, for example, smaller firms are more likely to report crime as a problem or whether firm-level efficiency is associated with reporting labour regulations as an obstacle.

\subsection{How does Government Regulation Compare to other Obstacles to Doing Business?}

In the ICA survey, firms were asked whether any of a set of issues were a problem for the operation and growth of their business, and if any were, were asked to rank the severity of the problem on a four point scale. Table 6 presents the results sorted by the percentage of firms that rated an obstacle as major or very severe. ${ }^{4}$ The categories that are related to government regulation are highlighted in the shaded rows of the table.

4 The order of the categories does not change significantly if they are ranked only by very severe obstacle, or by the sum of moderate obstacle, major obstacle or very severe obstacle. 
Table 6: The Severity of Perceived Obstacles to Business, ICA Survey

\begin{tabular}{|l|c|}
\hline Obstacle & $\begin{array}{c}\text { \% of respondents answering: } \\
\text { major or very severe obstacle }\end{array}$ \\
\hline Skills and education of available workers & 0.355 \\
\hline Macroeconomic instability (inflation, exchange rate) & 0.335 \\
\hline Labour regulations & 0.329 \\
\hline Crime, theft and disorder & 0.290 \\
\hline Tax rates & 0.186 \\
\hline Economic and regulatory policy uncertainty & 0.179 \\
\hline Customs and trade regulation & 0.167 \\
\hline Cost of financing (e.g. interest rates) & 0.164 \\
\hline Corruption & 0.161 \\
\hline Anti-competitive or informal practices & 0.156 \\
\hline Access to financing (e.g. collateral) & 0.126 \\
\hline Tax administration & 0.106 \\
\hline Transportation & 0.101 \\
\hline Electricity & 0.090 \\
\hline Legal system / conflict resolution & 0.088 \\
\hline Access to land & 0.036 \\
\hline Telecommunications & 0.035 \\
\hline Business licensing and operating permits & 0.035 \\
\hline Categories highlighted in grey relate to government regulation. & \\
\hline
\end{tabular}

The table shows that there is a gap between the four most frequently mentioned most serious obstacles and the rest. Worker skills, macroeconomic instability, labour regulations and crime are all cited by approximately a third of the firms in the sample as major or very severe obstacles. Of these four, only labour regulation is directly related to government regulation. The next most serious regulatory obstacle is the uncertainty surrounding regulatory policy followed by customs and trade regulation. Tax administration is mentioned by $\mathbf{1 0 . 6}$ per cent of firms as an obstacle. Very few firms view business licensing and obtaining operating permits as a significant constraint to the operation and growth of their business.

Firms were also given the opportunity to list up to three major obstacles to doing business in South Africa (see Table 7). Labour regulations were the most often mentioned obstacle. This was followed by a shortage of skilled labour. These results confirm the earlier finding - labour regulations are viewed by firms as a serious constraint to doing business in South Africa. 
Table 7: Major Obstacles Facing Firms, ICA Survey

\begin{tabular}{|l|c|}
\hline Obstacle & $\begin{array}{c}\text { \% of firms mentioning it } \\
\text { as a major obstacle }\end{array}$ \\
\hline Labour regulations & 46.43 \\
\hline Skilled labour shortage & 40.13 \\
\hline Other & 29.52 \\
\hline Crime and theft & 27.03 \\
\hline Competition from imports & 21.56 \\
\hline Tax regulations and/or high taxes & 17.74 \\
\hline Foreign currency regulations & 16.58 \\
\hline High interest rates & 13.60 \\
\hline Official corruption & 12.94 \\
\hline Bureaucratic burden & 8.79 \\
\hline Inadequate supply of infrastructure & 7.79 \\
\hline Insufficient demand for products & 7.63 \\
\hline High collateral requirements & 7.30 \\
\hline Inadequate access to credit & 7.13 \\
\hline Ownership regulations & 6.14 \\
\hline Import regime & 4.48 \\
\hline Utility prices & 4.48 \\
\hline Lack of business support services & 4.31 \\
\hline Regulations for starting a new business, new operations or expansion & 3.98 \\
\hline Obtaining land and buildings & 1.66 \\
\hline No problem & 1.49 \\
\hline Percentages sum to more than 100 since firms were asked for their three biggest obstacles. \\
\hline Categories highlighted in grey relate to government regulations. & \\
\hline
\end{tabular}

Figure 4 presents results for regulation related obstacles only. These are presented by firm size as measured by the number of employees. Labour regulations stand out as a constraint with more than double the number of firms citing these as a constraint than the next most common category. There is some indication that larger firms are more likely to mention these. Tax regulation is the second most mentioned regulatory obstacle. Smaller firms mention this more often than larger firms. Foreign currency regulations are the third most mentioned regulatory category and these are more often mentioned by larger firms. This is because larger firms are much more likely to participate in the international market than smaller firms (see Rankin, 2002, for an investigation of the export behaviour of South African firms). This is the case for import regulations as well - larger firms are more likely to mention these as a constraint than smaller firms. Less than 10 per cent of firms regard the other regulatory categories as one of their three biggest obstacles to doing business in South Africa. 
Figure 4: Firms' Major Obstacles that Relate to Regulation (\% of firms citing category as an obstacle), by Size (ICA Survey)

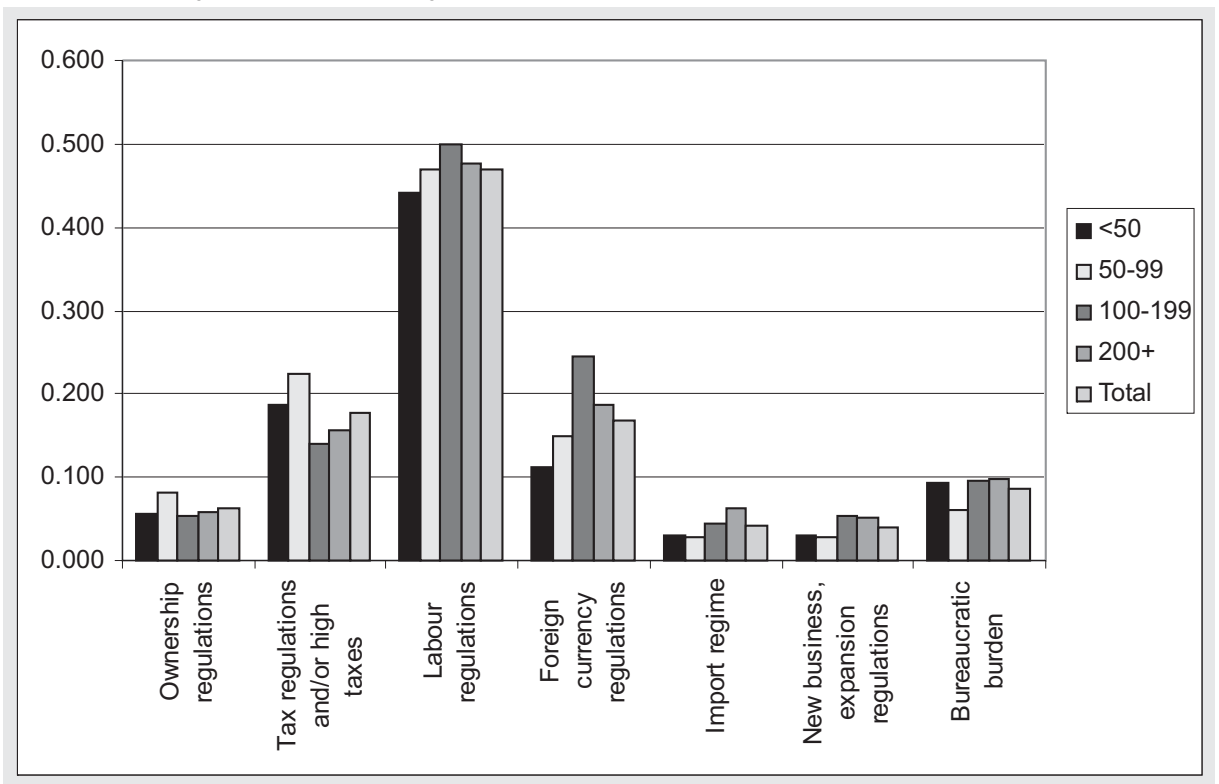

The WB/GJMA asked firms to rate the degree of seriousness of various potential obstacles to business. Table 8 summarises these responses. Crime and theft, and labour regulations both feature as one of the five most seriously regarded obstacles to business in both the 1998 and 2002 surveys. In both surveys labour regulation is regarded as the most serious regulatory obstacle to business. Between 1998 and 2002 it seems as if skills have become a more serious constraint to business. However, it is difficult to compare the magnitudes of the responses to these questions over time since firms were given different scales to rate the seriousness of the obstacles, and the set of the potential obstacles to be rated differed between the surveys. Therefore, it is best to examine the relative rankings of the obstacles.

As with the ICA, other government regulations were not perceived to be as serious as labour regulations. The second most serious set of regulations was tax regulations, followed by regulations related to trade and regulations related to expanding or starting a business. Environmental regulations were regarded by very few firms as a serious obstacle. 
Table 8: The Severity of Perceived Obstacles to Business, WB/GJMA Survey

\begin{tabular}{|l|c|c|c|}
\hline Obstacle & $\begin{array}{c}\text { Major } \\
\text { problem }\end{array}$ & $\begin{array}{c}\text { Moderate } \\
\text { problem }\end{array}$ & $\begin{array}{c}\text { Not a } \\
\text { problem }\end{array}$ \\
\hline Crime and theft & 0.67 & 0.28 & 0.06 \\
\hline Depreciation or weakening of Rand/Dollar exchange rate & 0.51 & 0.27 & 0.21 \\
\hline Cost of capital/credit & 0.50 & 0.30 & 0.20 \\
\hline Recent labour regulations & 0.43 & 0.37 & 0.20 \\
\hline Corruption in government & 0.39 & 0.29 & 0.31 \\
\hline Availability of technical/vocational labour skills & 0.27 & 0.42 & 0.31 \\
\hline Tax rates & 0.25 & 0.44 & 0.31 \\
\hline Change in government policies & 0.17 & 0.38 & 0.45 \\
\hline Tax regulations & 0.15 & 0.34 & 0.51 \\
\hline Export and import regulations/procedures & 0.13 & 0.32 & 0.55 \\
\hline $\begin{array}{l}\text { Regulations for expanding your current business and/or starting } \\
\text { a new business }\end{array}$ & 0.11 & 0.23 & 0.66 \\
\hline Infrastructure provision and quality & 0.06 & 0.29 & 0.66 \\
\hline Environmental regulations & 0.04 & 0.26 & 0.70 \\
\hline Categories highlighted in grey relate to government regulations. & & & \\
\hline
\end{tabular}

\subsection{What are the Major Obstacles Constraining the Expansion of Firms?}

To check the robustness of these results we use the SBP data to investigate the types of factors that firms list as constraints to firm expansion. These are divided by firm size category to investigate whether certain sized firms face different constraints to expansion. In this question firms were allowed open-ended answers and these were not grouped into categories by the enumerators. Rather, these were placed into categories during data entry. There were a number of categories - Figure 5 displays the most common.

Among all size categories the most commonly cited reason constraining expansion is weak demand in the economy. Labour problems are for most size categories the third most frequent constraint. This category includes answers such as labour market regulation and labour productivity but excludes answers such as access to skilled labour. In most cases labour problems are mentioned as a constraint to expansion by a similar number of firms that mention access to finance as a constraint. It is difficult to isolate the impacts of regulation from this question but it does support the results of the previous sub-section - labour regulations are widely regarded as a constraint to business. 
Figure 5: Constraints to Firm Expansion. SBP Survey. ( $n=1129)$

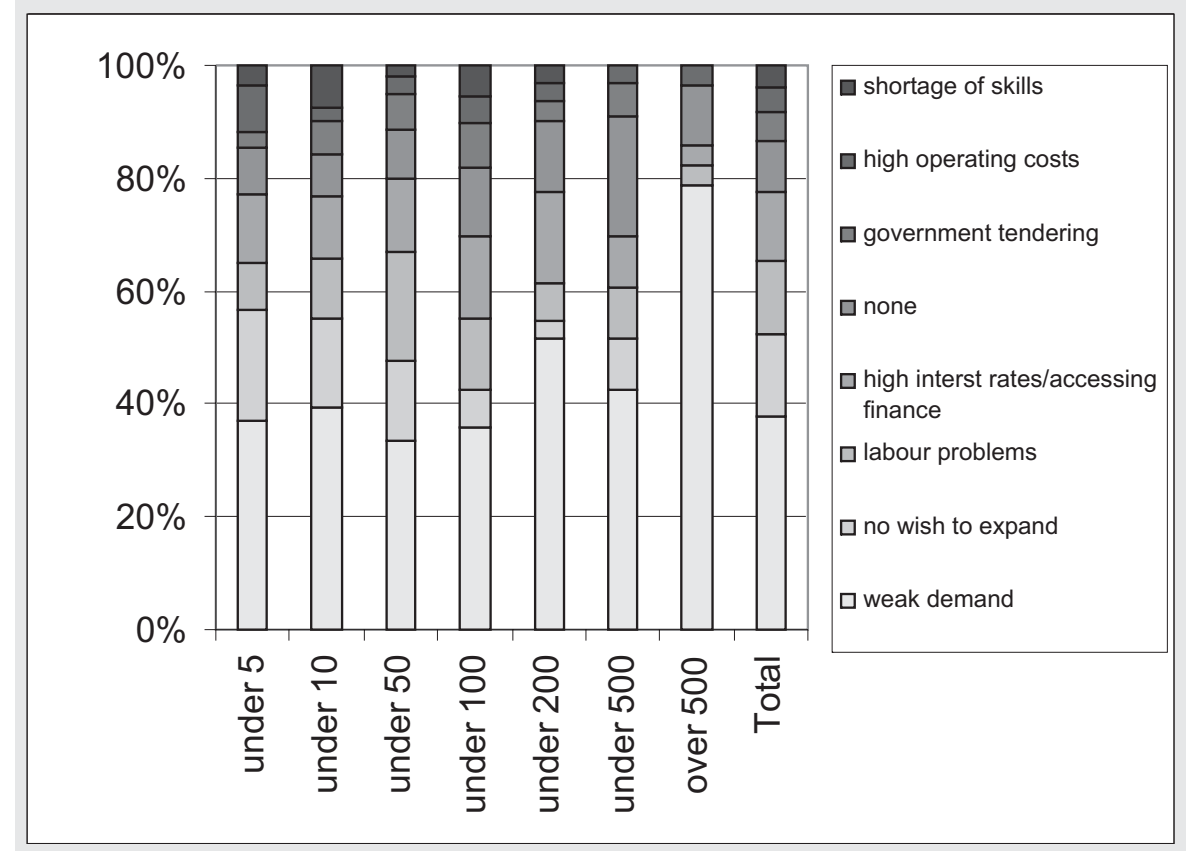

\subsection{Are Certain Types of Firms more likely to Report Certain Obstacles?}

The discussion so far has focused on the firms' perception of obstacles. There may be some subjectivity in the response of firms to these types of questions and firms may be inclined to exaggerate certain aspects. In order to deal with this we have specifically examined three of the most frequently cited obstacles - labour regulations, skills and crime - in both the ICA and WB/GJMA surveys and investigated whether certain firm characteristics are associated with mentioning these problems as obstacles. We have introduced measures of output and inputs into the specification which allows us to investigate the role of efficiency in the probability of reporting the category as an obstacle. ${ }^{5}$ We also control for foreign ownership, whether a firm exports or imports, firm age, the skills composition of the workforce, whether there is a union in the firm and sector and

5 The coefficient of the output per unit labour variable measures whether the total factor productivity (TFP) of the firm is significantly related to the probability of reporting the category as an obstacle. TFP is often measured as the residual (or unexplained) part of a Cobb-Douglas production function. These residuals can then be substituted into the logit (or probit) specification so that the coefficient of the output per unit labour variable measures the impact of TFP. Alternatively, the components of the production can be placed directly into the specification, as we have done. 
location specific factors. We are thus able to identify, for example, whether exporters are more likely to mention a certain obstacle than non-exporters. ${ }^{6}$ The specifications are slightly different between the ICA and WB/GJMA samples as the questions asked in each survey are different. However, we have tried to make the specifications as similar as possible.

We use a probit estimator and the dependent variable takes the value 1 if the firm reports that category as a moderate or major obstacle, and 0 otherwise for the WB/GJMA, and if the firm reports it as a moderate, major or very severe obstacle in the ICA survey. The results are reported in Table 9.

The results differ between the specifications. This could be because of the different population of firms sampled, differences in sample size or specification or because things have changed over time. However, our discussion will focus on similarities in the results bearing in mind these possible limitations.

6 This is an improvement but only partially deals with the subjective nature of the responses. If, for example, all firms in the textile sector are likely to exaggerate certain obstacles we will be able to pick up that textile firms are more likely to mention that category as an obstacle than non-textile firms. However, we will not be able to say whether this is because of some subjective exaggeration or another underlying sector specific issue. If this sector specific issue (be it exaggeration or something else) is only related to the textile sector and not related to, for example, size the coefficient estimates of the other variables will not be affected. 
Table 9: Firm Characteristics and Major Obstacles, Probit Estimation, ICA and WB/GJMA Surveys

\begin{tabular}{|c|c|c|c|c|c|c|}
\hline & $\overline{(1)}$ & $\overline{(2)}$ & $\overline{(3)}$ & 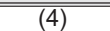 & 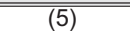 & $\overline{(\overline{(6)}}$ \\
\hline & \multicolumn{2}{|c|}{ Labour regulations } & \multicolumn{2}{|c|}{ Skills } & \multicolumn{2}{|c|}{ Crime } \\
\hline & WB/GJMA & ICA & WB/GJMA & ICA & WB/GJMA & ICA \\
\hline \multirow{2}{*}{ Ln(output/labour) } & -0.723 & 0.028 & 0.154 & 0.048 & -0.559 & 0.179 \\
\hline & $(1.96)^{\star}$ & $(0.23)$ & $(0.45)$ & $(0.41)$ & (1.11) & $(1.34)$ \\
\hline \multirow{2}{*}{ Ln(capital/labour) } & 0.037 & -0.054 & -0.005 & 0.026 & -0.050 & -0.062 \\
\hline & $(0.32)$ & $(1.03)$ & $(0.05)$ & $(0.50)$ & $(0.30)$ & $(1.15)$ \\
\hline \multirow{2}{*}{ Ln(employment) } & -0.148 & -0.011 & -0.042 & 0.164 & -0.022 & 0.102 \\
\hline & $(1.00)$ & $(0.16)$ & $(0.28)$ & $(2.30)^{\star *}$ & $(0.10)$ & $(1.46)$ \\
\hline \multirow{2}{*}{$\begin{array}{l}\text { Ln(raw } \\
\text { material/labour) }\end{array}$} & 0.183 & 0.002 & 0.156 & -0.170 & 0.455 & -0.219 \\
\hline & $(0.70)$ & $(0.02)$ & $(0.66)$ & $(1.69)^{*}$ & $(1.26)$ & $(1.95)^{*}$ \\
\hline \multirow{2}{*}{$\begin{array}{l}\text { Ln(other } \\
\text { costs/labour) }\end{array}$} & 0.395 & 0.166 & -0.030 & 0.218 & 0.190 & -0.053 \\
\hline & $(2.33)^{\star *}$ & $(2.53)^{\star *}$ & $(0.20)$ & $(3.36)^{\star * *}$ & $(0.74)$ & $(0.84)$ \\
\hline \multirow{2}{*}{ Age } & 0.007 & -0.002 & 0.007 & -0.010 & 0.003 & -0.006 \\
\hline & $(0.91)$ & $(0.49)$ & $(1.03)$ & $(2.93)^{\star \star \star *}$ & $(0.28)$ & $(1.85)^{*}$ \\
\hline \multirow{2}{*}{$\begin{array}{l}\% \text { with some } \\
\text { primary education }\end{array}$} & & 0.012 & & 0.010 & & 0.008 \\
\hline & & $(2.10)^{\star *}$ & & $(1.71)^{*}$ & & $(1.42)$ \\
\hline \multirow{2}{*}{$\begin{array}{l}\% \text { with } 6-9 \text { years } \\
\text { education }\end{array}$} & & 0.002 & & 0.007 & & 0.008 \\
\hline & & $(0.37)$ & & (1.27) & & $(1.53)$ \\
\hline \multirow{2}{*}{$\begin{array}{l}\% \text { with } 10-12 \\
\text { years education }\end{array}$} & & 0.003 & & 0.009 & & 0.005 \\
\hline & & $(0.62)$ & & $(1.69)^{*}$ & & $(0.93)$ \\
\hline \multirow{2}{*}{$\%$ skilled } & -0.014 & & 0.010 & & 0.757 & \\
\hline & $(0.01)$ & & $(0.04)$ & & $(0.45)$ & \\
\hline \multirow{2}{*}{$\%$ semi-skilled } & -0.055 & & 0.355 & & 0.874 & \\
\hline & $(0.11)$ & & $(1.26)$ & & (1.11) & \\
\hline \multirow{2}{*}{$\begin{array}{l}\text { Any foreign } \\
\text { ownership }\end{array}$} & 0.062 & -0.063 & -0.811 & 0.130 & 0.032 & 0.261 \\
\hline & $(0.20)$ & $(0.35)$ & $(1.07)$ & $(0.70)$ & $(0.07)$ & $(1.43)$ \\
\hline \multirow{2}{*}{ Export } & 0.559 & 0.213 & 0.010 & 0.047 & 0.058 & 0.098 \\
\hline & $(1.98)^{* \star}$ & (1.39) & $(0.04)$ & $(0.31)$ & $(0.14)$ & $(0.64)$ \\
\hline \multirow{2}{*}{ Import } & -0.359 & -0.233 & 0.355 & -0.008 & -0.462 & -0.179 \\
\hline & $(1.07)$ & $(1.58)$ & $(1.26)$ & $(0.06)$ & $(0.83)$ & $(1.20)$ \\
\hline \multirow{2}{*}{ Union dummy } & -0.423 & 0.346 & -0.811 & 0.058 & & 0.278 \\
\hline & $(0.58)$ & $(1.66)^{*}$ & $(1.07)$ & $(0.28)$ & & $(1.33)$ \\
\hline Sector controls: & Yes & Yes & Yes & Yes & Yes & Yes \\
\hline Province controls: & No & Yes & No & Yes & No & Yes \\
\hline Observations & 173 & 432 & 180 & 436 & 150 & 429 \\
\hline
\end{tabular}

Firms with a larger ratio of other costs (such as electricity or fuel) to labour are more likely to mention labour regulations as a major obstacle. Firms that export are also more likely to find the labour regulations onerous. There are conflicting results on whether firms with a union are more likely to cite labour regulations as a constraint to business. The results from the WB/GJMA sample suggest that less efficient firms are more likely to cite labour regulations as a severe constraint. Firms with a less educated labour force (those with a higher proportion of workers with only some primary education) are more likely to find labour regulations a constraint. We will investigate the relationship between labour regulations and the unskilled in more detail in a later section. 
There is very little that explains why firms in the WB/GJMA sample find the lack of skilled workers a constraint. However, in the ICA sample larger firms, those with a higher other costs to labour ratio, and those with lower raw material intensity are more likely to mention skills as a constraint. Younger firms are also more likely to find the lack of skills onerous. Furthermore, those firms with a higher proportion of people with only some primary school education, and those with a higher proportion of people with 10-12 years of education are more likely to mention skills as a constraint. A possible explanation for this is that there are two broad types of skills that firms find lacking in workers. The first is basic literacy and numeracy. Firms may expect employees with some primary school education to have these skills. The second is more advanced technical or vocational skills. These are the types of skills that firms may want employees with high school education to possess.

The results for both the WB/GJMA and ICA surveys indicate that crime and theft affects all firms. We can conclude this because there are very few firm characteristics that are significant variables that explain firms reporting this as an obstacle. 


\section{Government Regulation and Investment}

Investment is important for firm performance. It allows firms to increase production and scale, reduce costs and acts as a conduit for technical and productivity improvements. In competitive and dynamic markets firms that do not invest risk losing market share. Government regulation may change the incentives to invest. This section investigates the relationship between government regulation and investment in more detail.

This section is divided into four sub-sections. The first reports the type of obstacles firms perceive to discourage capital expenditure. The second investigates whether certain types of firms are more likely to report certain types of obstacles. The third sub-section examines whether firms that report certain types of obstacles are actually less likely to invest. We investigate whether these obstacles are related to the propensity to invest (whether a firm undertakes any investment) and the amount invested if the firm does invest. The last sub-section investigates the relationship between perceived obstacles and the type of investment a firm engages in.

\subsection{Obstacles Discouraging Investment}

As with the previous section, we begin by placing the perception of government regulation as a constraint to investment in context by comparing the perceived severity of government regulations against other obstacles. To do this we use a question from the NES that asks "To what degree have the following issues discouraged capital expenditure by your business since the start of 1998 ?"

The responses are presented in Figure 6. 
Figure 6: Obstacles to Capital Expenditure. NES Survey

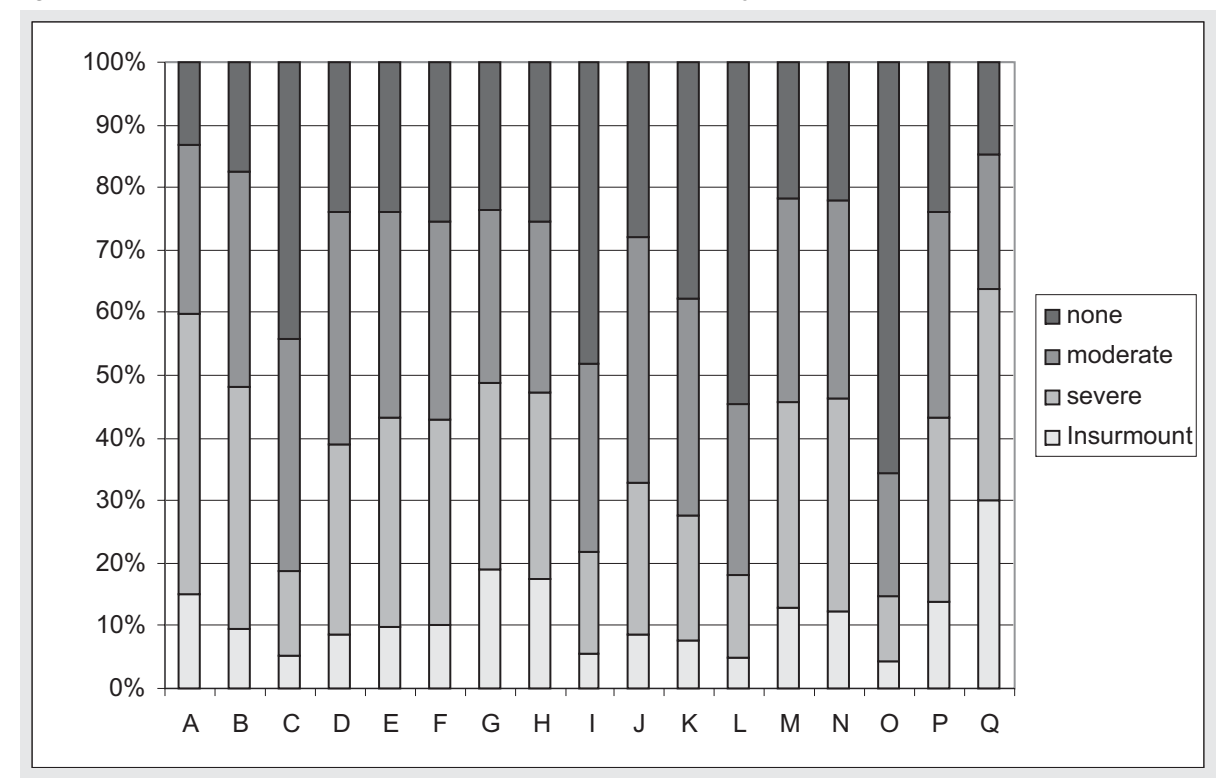

Potential Obstacles Categories. The number of observations varies between 762 and 1225.

A - interest rates for borrowing too high.

$B$ - Fluctuations in the interest rate

$\mathrm{C}$ - More attractive returns on alternative uses of funds

D - poor sales outlook in your industry

$\mathrm{E}$ - the level of the exchange rate

$\mathrm{F}$ - unstable rand exchange rate

$G$ - Labour regulations

$\mathrm{H}$ - uncertainty over your future labour relations

I - inability to penetrate export markets

$\mathrm{J}$ - increased competition in South African

markets
$\mathrm{K}$ - lack of own finance

$\mathrm{L}-$ lack of access to borrowed funds

$\mathrm{M}$ - high company income tax rates

$\mathrm{N}$ - inadequate tax incentives for investment

O - inadequate public infrastructure (power/ water etc)

$\mathrm{P}$ - uncertainty over government economic policy

$\mathrm{Q}$ - crime and related social problems 
Table 10: The Most Commonly Perceived Obstacles to Investment. NES Survey

\begin{tabular}{|c|l|c|l|c|}
\hline Rank & Severe and insurmountable & & Insurmountable & Freq. \\
\hline 1 & & Freq. & & $30 \%$ \\
\hline 2 & A - crime and related social problems & $64 \%$ & Q - crime and related social problems & $19 \%$ \\
\hline 3 & G - Labour regulations & $60 \%$ & G - Labour regulations & $17 \%$ \\
\hline 4 & B - Fluctuations in the interest rate & $48 \%$ & A- interest rates for borrowing too high & $15 \%$ \\
\hline 5 & $\begin{array}{l}\text { H- uncertainty over future labour } \\
\text { relations }\end{array}$ & $47 \%$ & P- uncertainty over government policy & $14 \%$ \\
\hline
\end{tabular}

The results are similar to the responses in Section 2. Crime and related social problems are the most frequently cited factor discouraging capital expenditure. Sixty-four per cent of firms claim that this is a severe or insurmountable problem. High interest rates are also widely cited as a constraint to investment with 60 per cent of firms that claim that these are either a severe or insurmountable problem. Labour regulations are also frequently mentioned as a constraint to investment. It is the third most common constraint for the severe and insurmountable category and the second most commonly mentioned insurmountable problem. Uncertainty about future labour regulations is also frequently mentioned as a constraint to investment. This survey was undertaken soon after the implementation of the new labour regulations and uncertainty regarding the implementation of these may have resulted in the high number of firms reporting this as a potential constraint.

The results presented here indicate that labour regulations are perceived to be a constraint to investment on the same scale as high interest rates. Only crime and theft is more often mentioned as a constraint to capital expenditure. 


\subsection{Are Certain Types of Firms more likely to Report Certain Types of Obstacles to Investment?}

As with the previous section we investigate whether certain firm characteristics are associated with the probability of reporting a category as a severe or insurmountable constraint. Since the NES survey does not have reliable information on raw material costs, the coefficient on the output/labour variable is a proxy for rather than an appropriate measure of efficiency. We report the results for the five most frequently cited severe and insurmountable constraints to capital investment in Table 11.

These results indicate that smaller firms are more likely to cite crime as a constraint than larger firms. Firms in the IT sector and those in the Eastern and Western Cape are also less likely to mention crime as a constraint to investment.

High interest rates are more likely to be a factor limiting investment for smaller firms and those with a lower proportion of semi-skilled workers (and thus a higher proportion of unskilled workers).

Labour regulation is more likely to be mentioned as a constraint by smaller firms and firms with a higher proportion of unskilled workers. The textile, furniture and print sectors are more likely to report labour market problems as an obstacle than the metal products sector while the tourism and retail sectors are less likely to report this as a constraint.

Those firms that report future uncertainty about labour market regulations as a constraint to investment share similar characteristics to those firms reporting labour market regulations as obstacle. More capital-intensive firms are more likely to report future uncertainty about labour regulations as obstacle and exporters are less likely to report this as a constraint. 
Table 11: Factors Influencing the Reporting of Potential Obstacles to Investment: Logit Specification, Firms that Report Obstacle as an Insurmountable or Severe

\begin{tabular}{|c|c|c|c|c|c|}
\hline & Q & A & G & $B$ & $\mathrm{H}$ \\
\hline Rank & 1 & 2 & 3 & 4 & 5 \\
\hline \multirow{2}{*}{ Ln(output/labour) } & -0.023 & -0.034 & -0.124 & -0.023 & -0.111 \\
\hline & $(-0.29)$ & $(-0.44)$ & $(-1.46)$ & $(-0.28)$ & $(-1.3)$ \\
\hline \multirow{2}{*}{ Ln(capital/labour) } & -0.026 & 0.003 & 0.063 & 0.089 & 0.131 \\
\hline & $(-0.43)$ & $(0.05)$ & (1.01) & $(1.48)$ & $(2.09)^{\star *}$ \\
\hline \multirow{2}{*}{ Ln(labour) } & -0.241 & -0.098 & -0.169 & -0.114 & -0.209 \\
\hline & $(-4.16)^{\star \star \star}$ & $(-1.78)^{*}$ & $(-2.74)^{\star \star \star}$ & $(-1.91)^{*}$ & $(-3.28)^{\star \star \star}$ \\
\hline \multirow{2}{*}{$\%$ skilled } & -0.737 & -0.798 & -2.521 & -0.366 & -2.280 \\
\hline & $(-1.11)$ & $(-1.25)$ & $(-3.36)^{\star * \star}$ & $(-0.55)$ & $(-2.96)^{\star \star \star}$ \\
\hline \multirow{2}{*}{$\%$ semi-skilled } & -0.478 & -0.537 & -1.304 & -0.423 & -1.007 \\
\hline & $(-1.56)$ & $(-1.8)^{\star}$ & $(-4.13)^{\star \star \star}$ & $(-1.36)$ & $(-3.17)^{\star \star \star}$ \\
\hline \multirow{2}{*}{ Firm age } & 0.003 & -0.004 & 0.003 & -0.010 & 0.006 \\
\hline & $(0.87)$ & $(-1.26)$ & $(0.82)$ & $(-2.68)^{\star * *}$ & $(1.6)$ \\
\hline \multirow{2}{*}{$\begin{array}{l}\text { Any foreign } \\
\text { ownership }\end{array}$} & -0.149 & -0.124 & 0.237 & -0.230 & 0.150 \\
\hline & $(-0.66)$ & $(-0.56)$ & $(0.99)$ & $(-0.92)$ & $(0.61)$ \\
\hline \multirow{2}{*}{$\begin{array}{l}\text { Any government } \\
\text { ownership }\end{array}$} & -0.286 & -0.655 & 0.235 & -0.183 & -0.181 \\
\hline & $(-0.47)$ & $(-1.05)$ & $(0.38)$ & $(-0.29)$ & $(-0.25)$ \\
\hline \multirow{2}{*}{ Any black ownership } & -0.015 & -0.153 & -0.225 & -0.580 & -0.333 \\
\hline & $(-0.05)$ & $(-0.5)$ & $(-0.64)$ & $(-1.59)$ & $(-0.91)$ \\
\hline \multirow{2}{*}{ Exports } & -0.189 & -0.008 & -0.174 & -0.012 & -0.359 \\
\hline & $(-1.17)$ & $(-0.05)$ & $(-1.03)$ & $(-0.07)$ & $(-2.09)^{*}$ \\
\hline \multirow{2}{*}{ Food sector } & 0.033 & 0.321 & 0.137 & 0.798 & 0.074 \\
\hline & $(0.11)$ & $(1.07)$ & $(0.45)$ & $(2.5)^{\star \star}$ & $(0.24)$ \\
\hline \multirow{2}{*}{ Wood sector } & 0.167 & 0.309 & 0.197 & 0.940 & 0.255 \\
\hline & $(0.56)$ & $(1.07)$ & $(0.66)$ & $(3.06)^{\star \star *}$ & $(0.85)$ \\
\hline \multirow{2}{*}{ Chemicals sector } & 0.116 & 0.545 & -0.225 & 0.601 & -0.249 \\
\hline & $(0.39)$ & $(1.89)^{*}$ & $(-0.73)$ & $(1.91)^{*}$ & $(-0.79)$ \\
\hline \multirow{2}{*}{ Vehicles sector } & -0.543 & 0.326 & 0.329 & 0.566 & 0.286 \\
\hline & $(-1.59)$ & $(1.01)$ & $(0.97)$ & $(1.57)$ & $(0.83)$ \\
\hline \multirow{2}{*}{ Textile sector } & 0.152 & 0.513 & 0.822 & 0.691 & 0.761 \\
\hline & $(0.51)$ & $(1.74)^{*}$ & $(2.72)^{\star \star *}$ & $(2.17)^{\star \star}$ & $(2.5)^{\star \star}$ \\
\hline \multirow{2}{*}{ Furniture sector } & 0.324 & 1.084 & 0.792 & 1.261 & 0.686 \\
\hline & $(0.97)$ & $(3.2)^{\star \star \star}$ & $(2.4)^{\star \star}$ & $(3.72)^{\star \star \star}$ & $(2.08)^{\star \star}$ \\
\hline \multirow{2}{*}{ Print sector } & -0.104 & 0.715 & 0.585 & 0.844 & 0.290 \\
\hline & $(-0.33)$ & $(2.24)^{\star \star}$ & $(1.82)^{\star}$ & $(2.5)^{\star *}$ & $(0.89)$ \\
\hline \multirow{2}{*}{ Financial sector } & -0.218 & 0.084 & -0.626 & 0.625 & -0.595 \\
\hline & $(-0.63)$ & $(0.25)$ & $(-1.57)$ & $(1.71)^{*}$ & $(-1.45)$ \\
\hline \multirow{2}{*}{ IT sector } & -0.972 & -0.111 & -0.585 & 0.352 & -0.555 \\
\hline & $(-2.85)^{\star \star \star}$ & $(-0.34)$ & $(-1.5)$ & $(0.98)$ & $(-1.42)$ \\
\hline \multirow{2}{*}{ Tourism sector } & 0.312 & -0.083 & -0.673 & 0.464 & -0.467 \\
\hline & $(0.91)$ & $(-0.26)$ & $(-1.92)^{*}$ & $(1.33)$ & $(-1.33)$ \\
\hline \multirow{2}{*}{ Retail sector } & -0.260 & 0.272 & -0.520 & 0.474 & -0.496 \\
\hline & $(-0.9)$ & $(0.96)$ & $(-1.71)^{*}$ & $(1.53)$ & $(-1.6)$ \\
\hline Region controls: & Yes & Yes & Yes & Yes & Yes \\
\hline $\mathrm{N}$ & 944 & 953 & 942 & 935 & 937 \\
\hline Log likelihood & -612.23 & -634.59 & -579.63 & -587.22 & -570.80 \\
\hline \multicolumn{6}{|c|}{$\begin{array}{l}\text { A - interest rates for borrowing too high } \\
B-\text { Fluctuations in the interest rate } \\
G \text { - Labour regulations } \\
H-\text { uncertainty over future labour relations } \\
Q-\text { crime and related social problems } \\
\text { *** significant at the } 1 \% \text { level, }{ }^{* *} \text { significant at the } 5 \% \text { level, * significant at the } 10 \% \text { level. } \\
\text { z-statistics in parenthesis. } \\
\text { The metal sector is the base sector. }\end{array}$} \\
\hline
\end{tabular}


For the five most commonly perceived obstacles size is significantly associated with the probability of reporting the category as an obstacle. In all cases smaller firms are more likely to report the factor as an obstacle but the magnitude of the effect differs. Since the estimations are logits we cannot simply read off the magnitudes from the coefficients. Thus, in order to asses the magnitude of the relationship between firm size and the probability of reporting the problem we have graphed these for various sized firms. These results are presented in Figure 7. These results are the predicted probabilities of reporting the factor an obstacle for a firm with the average sample characteristics for various firm sizes. This enables us to isolate the size effect but does not take into account the fact that other factors, such as efficiency and capital intensity, may change with an increase in size. The results indicate that the probability of mentioning high interest rates as a constraint to investment declines with size but at a less rapid rate than crime. The rate of decline with size of crime and labour regulations is similar. This suggests that unlike high interest rates, where there is only a small difference in effect across size categories, crime and labour regulations are much larger relative constraints for small firms.

Figure 7: The Predicted Probability of aFirm Reporting the Factor as an Obstacle to Investment

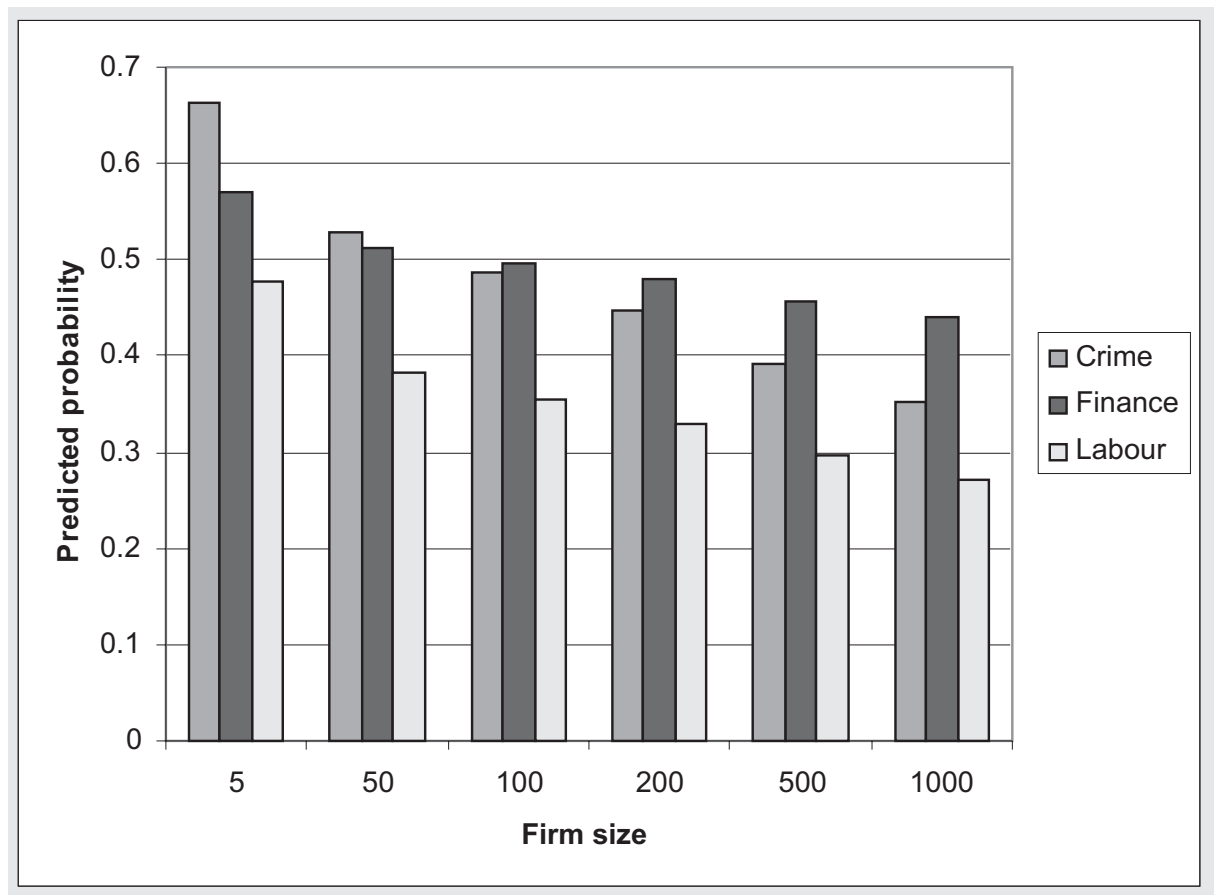




\subsection{Is the Propensity and Amount Invested Related to Reported Obstacles?}

We have examined the types of obstacles that firms mention as constraints to investment and whether certain types of firms are more likely to mention certain factors as constraints. In this sub-section we investigate whether firms that mention certain constraints to investment are actually less likely to invest and whether this affects the amount invested. In order to investigate this we estimate a logit model for whether a firm invests or not. We include as explanatory variables a set of dummies for whether the firm perceives the potential constraints as severe or insurmountable obstacles to investment. In the second stage we confine the sample to firms that have engaged in investment and investigate whether reporting certain factors as barriers to investment affects the amount invested conditional on the firm investing. 
Table 12: The Determinants of Investment. NES Survey

\begin{tabular}{|c|c|c|}
\hline & Propensity to invest & Amount invested: Ln(investment/turnover) \\
\hline & Logit & OLS \\
\hline \multirow{2}{*}{ Ln(output/labour) } & 0.319 & -0.885 \\
\hline & $(2.19)^{\star *}$ & $(-15.26)^{\star \star *}$ \\
\hline \multirow{2}{*}{ Ln(capital/labour) } & 0.097 & 0.299 \\
\hline & $(0.91)$ & $(6.25)^{\star * *}$ \\
\hline \multirow{2}{*}{ Ln(labour) } & 0.840 & 0.076 \\
\hline & $(4.87)^{\star * *}$ & $(2.19)^{\star *}$ \\
\hline \multirow{2}{*}{$\%$ skilled } & 2.085 & 1.541 \\
\hline & $(1.37)$ & $(3.65)^{\star \star *}$ \\
\hline \multirow{2}{*}{$\%$ semi-skilled } & 0.437 & 0.087 \\
\hline & $(0.8)$ & $(0.37)$ \\
\hline \multirow{2}{*}{ Firm age } & -0.006 & -0.006 \\
\hline & $(-0.81)$ & $(-2.7)^{\star \star \star}$ \\
\hline \multirow{2}{*}{ Any foreign ownership } & -0.260 & 0.140 \\
\hline & $(-0.43)$ & (1.01) \\
\hline \multirow{2}{*}{ Any government ownership } & & 0.120 \\
\hline & & $(0.41)$ \\
\hline \multirow{2}{*}{ Any black ownership } & -0.063 & -0.144 \\
\hline & $(-0.08)$ & $(-0.58)$ \\
\hline \multirow[b]{2}{*}{ Exports } & -0.052 & 0.234 \\
\hline & $(-0.16)$ & $(2.05)^{\star \star}$ \\
\hline \multirow{2}{*}{ A - interest rates for borrowing too high } & -0.038 & -0.006 \\
\hline & $(-0.12)$ & $(-0.05)$ \\
\hline \multirow{2}{*}{ B - Fluctuations in the interest rate } & -0.249 & -0.022 \\
\hline & $(-0.75)$ & $(-0.17)$ \\
\hline \multirow{2}{*}{ C - More attractive returns on alternative uses of funds } & -0.690 & -0.054 \\
\hline & $(-1.87)^{*}$ & $(-0.33)$ \\
\hline \multirow{2}{*}{ D - poor sales outlook in your industry } & -0.355 & -0.270 \\
\hline & $(-1.24)$ & $(-2.26)^{\star \star}$ \\
\hline \multirow{2}{*}{$E$ - the level of the exchange rate } & 0.940 & 0.087 \\
\hline & $(1.88)^{\star}$ & $(0.48)$ \\
\hline \multirow{2}{*}{$\mathrm{F}$ - unstable rand exchange rate } & -0.704 & 0.125 \\
\hline & $(-1.43)$ & $(0.66)$ \\
\hline \multirow{2}{*}{ G - Labour regulations } & 0.916 & -0.018 \\
\hline & $(2.06)^{\star \star}$ & $(-0.11)$ \\
\hline \multirow{2}{*}{$\mathrm{H}$ - uncertainty over your future labour relations } & -0.489 & -0.192 \\
\hline & $(-1.11)$ & $(-1.13)$ \\
\hline & -0.189 & 0.217 \\
\hline I- Inability to penetrate export markets & $(-0.44)$ & $(1.35)$ \\
\hline & 0.519 & -0.152 \\
\hline J - Increased competition in South Atrican markets & $(1.56)$ & $(-1.11)$ \\
\hline K - lack of own finance & 0.039 & -0.184 \\
\hline k - rack or own minance & $(0.11)$ & $(-1.23)$ \\
\hline & 0.239 & 0.410 \\
\hline $\mathrm{L}$ - lack of access to borrowed funds & $(0.53)$ & $(2.21)^{\star \star}$ \\
\hline & -0.143 & 0.104 \\
\hline $\mathrm{M}$ - high company income tax rates & $(-0.42)$ & $(0.78)$ \\
\hline & 0.107 & -0.292 \\
\hline $\mathrm{N}$ - Inadequate tax incentives for investment & $(0.31)$ & $(-2.28)^{\star *}$ \\
\hline & -0.563 & -0.089 \\
\hline - inadequate public infrastructure (power/water etc) & $(-1.16)$ & $(-0.36)$ \\
\hline & -0.557 & 0.128 \\
\hline P - uncertainty over government economic policy & $(-1.66)^{*}$ & $(0.96)$ \\
\hline & 0.264 & 0.108 \\
\hline Q-crime and related social problems & $(0.82)$ & $(0.94)$ \\
\hline $\mathrm{N}$ & 845 & 770 \\
\hline Log likelihood, $\mathrm{R}^{2}$ & -228.63 & 0.31 \\
\hline $\begin{array}{l}\text { *** significant at the } 1 \% \text { level, }{ }^{* *} \text { significant at the } 5 \% \text { lev } \\
\text { z/t-statistics in parenthesis. } \\
\text { Regional and sector controls included }\end{array}$ & cant at the $10 \%$ level. & \\
\hline
\end{tabular}


These results show that larger firms are more likely to invest and if they do, are likely to spend a larger proportion of turnover. More efficient firms are also more likely to invest but efficiency tends to be negatively related to the amount invested. Firms with a high capitalto-labour ratio invest a higher proportion of their turnover if they invest. Firms with a large proportion of skilled workers and those firms that export also invest larger amounts if they invest. There are some differences in investment behaviour across sectors and regions.

The only categories that are negatively related to the propensity to invest are: $\mathrm{C}-$ More attractive returns on alternative uses of funds, and $P$ - Uncertainty over government policy. Surprisingly, firms that mention either labour regulations or the exchange rate as constraints to investment are actually more likely to engage in investment than firms that did not mention these as constraints.

Mentioning a poor sales outlook or a lack of investment incentives is negatively associated with the amount invested, if a firm decides to invest. Those firms that cite a lack of access to borrowed funds are actually likely to invest a higher proportion of turnover than those who do not mention this as a constraint.

Surprisingly, these results indicate that firms that mention labour regulations as a constraint to investment are actually more likely to invest than firms that do not mention this as a constraint. This may mean that labour regulations are actually not a binding constraint to investment, or that firms that find the labour regulations a constraint are investing more in an effort to substitute capital for labour, or that causality runs the other way - firms that are more likely to invest are more likely to cite labour regulations as a constraint. We investigate this further in the next sub-section by looking at the type of investment that the firm undertakes. 


\subsection{The Type of Investment and Perceived Obstacles}

The type of investment a firm engages in is important. Investment in plant and machinery may result in larger long-term productivity gains, through, for example, technology transfers, than investing in a motor vehicle for the Managing Director. In this sub-section we investigate the relationship between mentioned obstacles to capital expenditure and the type of investment. Investment is divided into four categories, investment in: machinery and equipment; vehicles; computers; and land and buildings.

As before we have two estimations for each category of investment. The first is a logit on whether the firm invests or not, and the second is an OLS regression on the natural logarithm of the ratio of investment to turnover. The results are reported in Table 13.

Firms that report more attractive returns from alternative uses of funds; poor sales outlook; the unstable exchange rate; and inadequate tax incentives for investment as barriers to investment are less likely to invest in plant and machinery than firms that do not report these as obstacles. Citing the level of the exchange rate; lack of access to borrowed funds and crime as barriers to investment are actually positively associated with investment in plant and machinery. Those firms that mention labour regulations as a constraint to investment are more likely to invest in plant and machinery but this is only significant at the 15 per cent level. None of the reported constraints are significantly associated with the amount invested in plant and machinery once the firm invests.

Vehicle investment is negatively associated with reporting a poor sales outlook as a constraint. High interest rates and the inability to penetrate export markets as constraints to investment are actually positively associated with investment in vehicles. If a firm engages in any investment in vehicles, the amount invested is negatively associated with inadequate tax incentives for investment and inadequate infrastructure. High company income tax rates and crime as constraints are positively associated with the amount invested in vehicles. 
Table 13: The Determinants of Investment, by Investment Type. NES Survey

\begin{tabular}{|c|c|c|c|c|c|c|c|c|}
\hline \multirow[t]{2}{*}{ Category } & \multicolumn{2}{|c|}{ Machines and equipment } & \multicolumn{2}{|c|}{ Vehicles } & \multicolumn{2}{|c|}{ Computers } & \multicolumn{2}{|c|}{ Land and buildings } \\
\hline & Investment & Amount & Investment & Amount & Investment & Amount & Investment & Amount \\
\hline \multirow[b]{2}{*}{ A } & -0.152 & -0.091 & 0.435 & 0.043 & 0.062 & -0.095 & 0.229 & -0.709 \\
\hline & $(-0.73)$ & $(-0.56)$ & $(2.21)^{\star \star}$ & $(0.35)$ & $(0.28)$ & $(-0.86)$ & $(0.85)$ & $(-1.7)^{\star}$ \\
\hline \multirow{2}{*}{ B } & 0.141 & 0.080 & -0.259 & 0.087 & -0.142 & 0.101 & -0.049 & -0.144 \\
\hline & $(0.65)$ & $(0.47)$ & $(-1.26)$ & $(0.69)$ & $(-0.62)$ & $(0.83)$ & $(-0.17)$ & $(-0.29)$ \\
\hline \multirow{2}{*}{ C } & -0.473 & 0.056 & 0.065 & -0.263 & -0.120 & -0.126 & -0.498 & -0.385 \\
\hline & $(-1.82)^{\star}$ & $(0.24)$ & $(0.27)$ & $(-1.59)$ & $(-0.43)$ & $(-0.84)$ & $(-1.35)$ & $(-0.61)$ \\
\hline \multirow{2}{*}{ D } & -0.522 & -0.055 & -0.663 & -0.139 & -0.329 & 0.018 & -0.513 & 0.185 \\
\hline & $(-2.76)^{\star \star \star}$ & $(-0.33)$ & $(-3.75)^{\star * *}$ & $(-1.16)$ & $(-1.69)^{*}$ & $(0.16)$ & $(-2.07)^{\star *}$ & $(0.39)$ \\
\hline \multirow{2}{*}{ E } & 0.549 & 0.244 & 0.250 & -0.094 & 0.010 & 0.084 & -0.010 & -0.520 \\
\hline & $(1.8)^{\star}$ & $(1.12)$ & $(0.93)$ & $(-0.42)$ & $(0.03)$ & $(0.46)$ & $(-0.03)$ & $(-0.82)$ \\
\hline \multirow{2}{*}{$\mathrm{F}$} & -0.676 & -0.038 & 0.132 & 0.007 & -0.196 & -0.116 & -0.234 & 0.649 \\
\hline & $(-2.17)^{\star \star}$ & $(-0.16)$ & $(0.47)$ & $(0.03)$ & $(-0.61)$ & $(-0.64)$ & $(-0.61)$ & $(0.96)$ \\
\hline \multirow{2}{*}{ G } & 0.448 & -0.022 & 0.218 & 0.074 & 0.617 & 0.135 & 0.086 & 0.245 \\
\hline & $(1.62)$ & $(-0.1)$ & $(0.86)$ & $(0.44)$ & $(2.11)^{\star \star}$ & $(0.88)$ & $(0.25)$ & $(0.37)$ \\
\hline \multirow{2}{*}{$\mathrm{H}$} & -0.394 & -0.233 & -0.060 & -0.040 & -0.421 & -0.174 & -0.179 & 0.205 \\
\hline & $(-1.4)$ & $(-1.07)$ & $(-0.23)$ & $(-0.24)$ & $(-1.44)$ & $(-1.09)$ & $(-0.52)$ & $(0.28)$ \\
\hline \multirow{2}{*}{ I } & 0.451 & 0.018 & 0.443 & 0.008 & -0.102 & -0.014 & 0.194 & 0.560 \\
\hline & $(1.64)$ & $(0.08)$ & $(1.77)^{*}$ & $(0.05)$ & $(-0.37)$ & $(-0.08)$ & $(0.59)$ & $(1.08)$ \\
\hline \multirow[b]{2}{*}{$J$} & 0.038 & -0.144 & 0.055 & 0.045 & 0.065 & -0.209 & 0.104 & -0.345 \\
\hline & $(0.19)$ & $(-0.87)$ & $(0.29)$ & $(0.38)$ & $(0.3)$ & $(-1.59)$ & $(0.4)$ & $(-0.68)$ \\
\hline \multirow{2}{*}{$\mathrm{K}$} & -0.203 & -0.105 & -0.055 & 0.010 & -0.073 & 0.127 & -0.518 & 0.406 \\
\hline & $(-0.85)$ & $(-0.51)$ & $(-0.24)$ & $(0.06)$ & $(-0.3)$ & $(0.88)$ & $(-1.53)$ & $(0.46)$ \\
\hline \multirow{2}{*}{ L } & 0.599 & 0.200 & 0.125 & 0.101 & 0.540 & 0.070 & 0.661 & -0.381 \\
\hline & $(2)^{\star *}$ & $(0.84)$ & $(0.44)$ & $(0.55)$ & $(1.72)^{\star}$ & $(0.39)$ & $(1.65)^{*}$ & $(-0.37)$ \\
\hline \multirow{2}{*}{ M } & 0.289 & 0.005 & -0.116 & 0.335 & 0.254 & 0.010 & 0.206 & -0.498 \\
\hline & $(1.33)$ & $(0.03)$ & $(-0.57)$ & $(2.6)^{\star \star \star}$ & $(1.11)$ & $(0.08)$ & $(0.72)$ & $(-1.02)$ \\
\hline \multirow[b]{2}{*}{$\mathrm{N}$} & -0.425 & 0.003 & -0.230 & -0.356 & -0.411 & -0.054 & -0.210 & 0.075 \\
\hline & $(-1.99)^{* *}$ & $(0.02)$ & $(-1.16)$ & $(-2.72)^{\star \star \star \star}$ & $(-1.84)^{*}$ & $(-0.42)$ & $(-0.78)$ & $(0.18)$ \\
\hline \multirow{2}{*}{$\mathrm{O}$} & -0.256 & 0.047 & -0.205 & -0.597 & 0.101 & -0.113 & -0.067 & 0.082 \\
\hline & $(-0.71)$ & $(0.14)$ & $(-0.61)$ & $(-2.41)^{\star \star}$ & $(0.27)$ & $(-0.6)$ & $(-0.15)$ & $(0.08)$ \\
\hline \multirow{2}{*}{$\mathrm{P}$} & 0.008 & 0.070 & -0.004 & 0.105 & 0.290 & 0.033 & -0.101 & -0.387 \\
\hline & $(0.04)$ & $(0.4)$ & $(-0.02)$ & $(0.88)$ & $(1.27)$ & $(0.26)$ & $(-0.36)$ & $(-0.8)$ \\
\hline \multirow{2}{*}{ Q } & 0.385 & -0.021 & 0.218 & 0.211 & 0.037 & -0.014 & 0.468 & 0.837 \\
\hline & $(1.93)^{*}$ & $(-0.15)$ & $(1.19)$ & $(1.77)^{*}$ & $(0.18)$ & $(-0.13)$ & $(1.86)^{*}$ & $(2.35)^{\star \star}$ \\
\hline
\end{tabular}

$A$ - interest rates for borrowing too high.

$B$ - Fluctuations in the interest rate

C - More attractive returns on alternative uses of funds

D - poor sales outlook in your industry

$\mathrm{E}$ - the level of the exchange rate

$\mathrm{F}$ - unstable rand exchange rate

$\mathrm{G}$ - Labour regulations

$\mathrm{H}$ - uncertainty over your future labour Q-crime and related social problems.

I - inability to penetrate export markets

$\mathrm{J}$ - increased competition in South African

markets 
Firms that mention a poor sales outlook and inadequate tax incentives as constraints to investment are less likely to invest in computers. Those that mention labour regulations or lack of access to borrowed funds are more likely to invest in computers. None of the reported constraints are associated with the amount invested in computers once the firm invests.

Firms with a poor sales outlook are less likely to invest in land and buildings. Those with a lack of access to borrowed funds and those that mention crime as a barrier to investment are actually more likely to invest in land and buildings. The amount invested is also positively related to reporting crime as a constraint but negatively related to reporting that interest rates are too high. 


\section{Labour Regulations and Employment}

Labour regulations are the type of regulation most frequently mentioned as a constraint to business in general and to investment. In this section we specifically examine how labour regulations impact on employment. We also investigate whether the consequences of these regulations falls disproportionately on certain types of workers or sizes of firms.

In the first sub-section we investigate whether firms perceive labour laws as an obstacle to hiring new employees, and how these compare as an obstacle to other potential obstacles such as the lack of relevant skills or the high cost of labour.

The second sub-section looks at the way labour regulations affect employment in comparison to other factors such as a change in market outlook. The third sub-section investigates how firms respond to labour regulations. The fourth sub-section examines whether labour regulations affect employment growth at the firm level and whether these effects differ by the type of regulation. The fifth sub-section investigates which specific parts of the regulations constrain the hiring of new employees and which impact on production costs. The last sub-section investigates whether we can identify benefits to firms, such as improved labour productivity, from the labour regulations.

\subsection{Do Firms Perceive the Labour Laws as an Obstacle to Hiring New Employees?}

There are a number of potential constraints to hiring new employees of which labour regulations may be one. To investigate this we use a question in the SBP survey that asks about the constraints faced by firms when hiring new employees. 
Figure 8: The Constraints Faced by Firms when hiring New Employees. SBP Survey $(n=1153)$

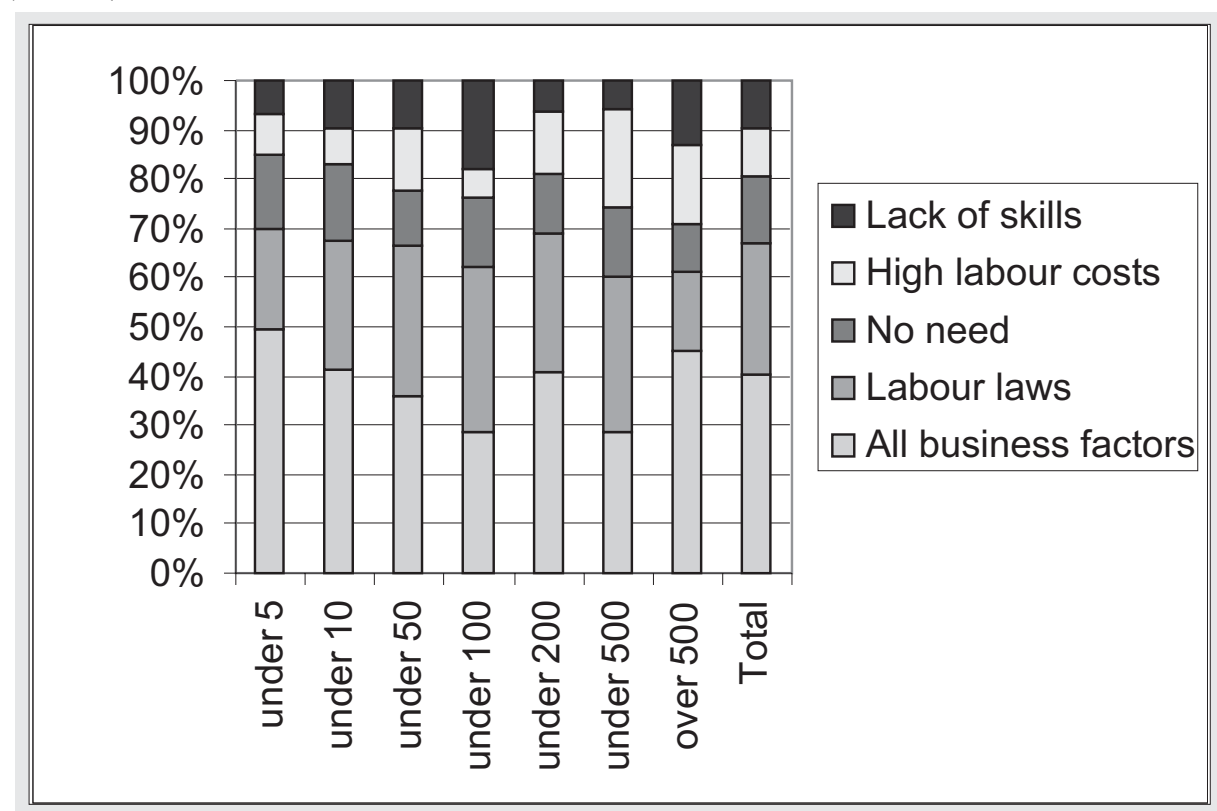

Labour laws are the most frequently mentioned constraint to hiring new employees after all other business factors. This is the case for all size categories. In fact, labour regulations are cited more often as a constraint to hiring than lack of skills. In the 51-100 employee size category, one-third of the firms cite the labour laws as their major constraint to hiring new employees.

\subsection{How do the Effects of Labour Regulation on Employment Compare to the Effects of Other Factors?}

We use the NES survey to investigate the factors firms report as reasons for a change in employment. Initially we look at what factors firms cite as important for firms that experienced an increase in employment and how these differ by skills category. The most common reason given for an increase in employment in all skills categories is a change in production level due to market outlook. These results are reported in the first half of Table 14.

We next examine the factors that influence a decrease in employment by skills levels. In most skill categories the most common reason given for a decrease in employment 
is a change in the market outlook (the category for reasons other than listed is the most common category in those skills categories where a change in market outlook does not rank first). A change in organisation within the plant is also a common reason given for a decrease in employment numbers.

Table 14: Reasons for a Change in Employment, by Skills Group. NES Survey

\begin{tabular}{|c|c|c|c|c|c|c|c|c|c|c|}
\hline \multicolumn{11}{|c|}{ An increase in employment. } \\
\hline & \multicolumn{2}{|c|}{ Management } & \multicolumn{2}{|c|}{ Sales } & \multicolumn{2}{|c|}{ Technical } & \multicolumn{2}{|c|}{ Semi-skilled } & \multicolumn{2}{|c|}{ Unskilled } \\
\hline & Freq. & $\%$ & Freq. & $\%$ & Freq. & $\%$ & Freq. & $\%$ & Freq. & $\%$ \\
\hline A & 28 & $18.4 \%$ & 22 & $11.5 \%$ & 24 & $15.9 \%$ & 31 & $25.0 \%$ & 27 & $16.2 \%$ \\
\hline B & 48 & $31.6 \%$ & 88 & $46.1 \%$ & 62 & $41.1 \%$ & 50 & $40.3 \%$ & 77 & $46.1 \%$ \\
\hline C & 4 & $2.6 \%$ & 6 & $3.1 \%$ & 5 & $3.3 \%$ & 3 & $2.4 \%$ & 11 & $6.6 \%$ \\
\hline $\mathrm{D}$ & 1 & $0.7 \%$ & & $0.0 \%$ & 8 & $5.3 \%$ & 1 & $0.8 \%$ & 4 & $2.4 \%$ \\
\hline$E$ & 0 & $0.0 \%$ & 0 & $0.0 \%$ & 1 & $0.7 \%$ & 1 & $0.8 \%$ & 0 & $0.0 \%$ \\
\hline $\mathrm{F}$ & 19 & $12.5 \%$ & 21 & $11.0 \%$ & 19 & $12.6 \%$ & 17 & $13.7 \%$ & 17 & $10.2 \%$ \\
\hline G & 2 & $1.3 \%$ & 2 & $1.0 \%$ & 3 & $2.0 \%$ & 3 & $2.4 \%$ & 4 & $2.4 \%$ \\
\hline $\mathrm{H}$ & 3 & $2.0 \%$ & 4 & $2.1 \%$ & 1 & $0.7 \%$ & 2 & $1.6 \%$ & 2 & $1.2 \%$ \\
\hline 1 & 47 & $30.9 \%$ & 48 & $25.1 \%$ & 28 & $18.5 \%$ & 16 & $12.9 \%$ & 25 & $15.0 \%$ \\
\hline Total & 152 & $100.0 \%$ & 191 & $100.0 \%$ & 151 & $100.0 \%$ & 124 & $100.0 \%$ & 167 & $100.0 \%$ \\
\hline \multicolumn{11}{|c|}{ A decrease in employment. } \\
\hline & \multicolumn{2}{|c|}{ Management } & \multicolumn{2}{|c|}{ Sales } & \multicolumn{2}{|c|}{ Technical } & \multicolumn{2}{|c|}{ Semi-skilled } & \multicolumn{2}{|c|}{ Unskilled } \\
\hline & Freq. & $\%$ & Freq. & $\%$ & Freq. & $\%$ & Freq. & $\%$ & Freq. & $\%$ \\
\hline A & 4 & $2.4 \%$ & 1 & $0.5 \%$ & 2 & $1.3 \%$ & 1 & $0.6 \%$ & 6 & $2.4 \%$ \\
\hline$B$ & 42 & $25.5 \%$ & 60 & $30.3 \%$ & 45 & $29.4 \%$ & 52 & $30.2 \%$ & 53 & $21.6 \%$ \\
\hline C & 8 & $4.8 \%$ & 8 & $4.0 \%$ & 9 & $5.9 \%$ & 20 & $11.6 \%$ & 48 & $19.6 \%$ \\
\hline$D$ & 10 & $6.1 \%$ & 12 & $6.1 \%$ & 16 & $10.5 \%$ & 12 & $7.0 \%$ & 26 & $10.6 \%$ \\
\hline$E$ & 2 & $1.2 \%$ & 2 & $1.0 \%$ & 12 & $7.8 \%$ & 12 & $7.0 \%$ & 8 & $3.3 \%$ \\
\hline $\mathrm{F}$ & 32 & $19.4 \%$ & 33 & $16.7 \%$ & 16 & $10.5 \%$ & 26 & $15.1 \%$ & 25 & $10.2 \%$ \\
\hline $\mathrm{G}$ & 12 & $7.3 \%$ & 20 & $10.1 \%$ & 9 & $5.9 \%$ & 10 & $5.8 \%$ & 23 & $9.4 \%$ \\
\hline $\mathrm{H}$ & 3 & $1.8 \%$ & 6 & $3.0 \%$ & 4 & $2.6 \%$ & 5 & $2.9 \%$ & 8 & $3.3 \%$ \\
\hline I & 52 & $31.5 \%$ & 56 & $28.3 \%$ & 40 & $26.1 \%$ & 34 & $19.8 \%$ & 48 & $19.6 \%$ \\
\hline Total & 165 & $100.0 \%$ & 198 & $100.0 \%$ & 153 & $100.0 \%$ & 172 & $100.0 \%$ & 245 & $100.0 \%$ \\
\hline
\end{tabular}

A-Capital expenditure raising full capacity level B-Change in production level due to market outlook (no change in full capacity production level)

C-Changes in labour laws and regulation

D-Outsourcing and contracting

E-New machinery requiring fewer employees at any given production level
F-Change in organisation of production within plant (no change in full capacity production level)

G-Higher wages or salaries

$\mathrm{H}$-Higher non-wage employee costs (benefits, hiring costs etc)

I-Reason is different from all of the above 
The ranking of the reasons for a decline in employment differs between skills groups. A change in the labour laws is the second most common reason for a decline in employment among the unskilled. The effect of a change in market outlook and the change in labour laws on the different skill types by firm size is illustrated in Figures 9-10.

These results illustrate that the change in the labour laws have had a similar impact on the decrease in employment among the unskilled to changes in market conditions. Among smaller firms labour regulations are a more common reason given for a decrease in unskilled employees than changes in market conditions.

Figure 9: Percentage of Firms Reporting a Change in Production Level Due to Market Outlook as the Single Most Important Reason for a Decrease in Employment in 1998. NES Survey.

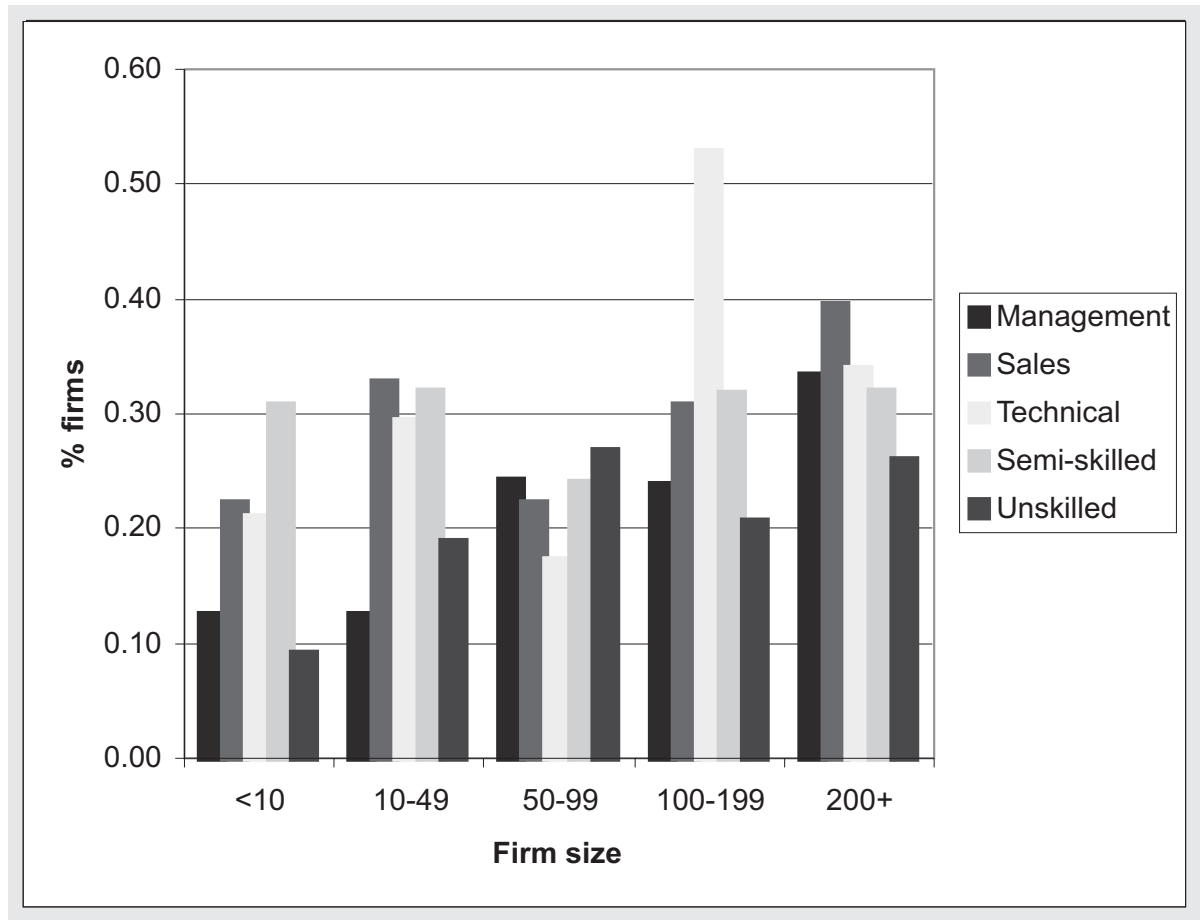


Figure 10: Percentage of Firms Reporting Changes in Labour Laws and Regulation as the Single Most Important Reason for a Decrease in Employment in 1998. NES Survey.

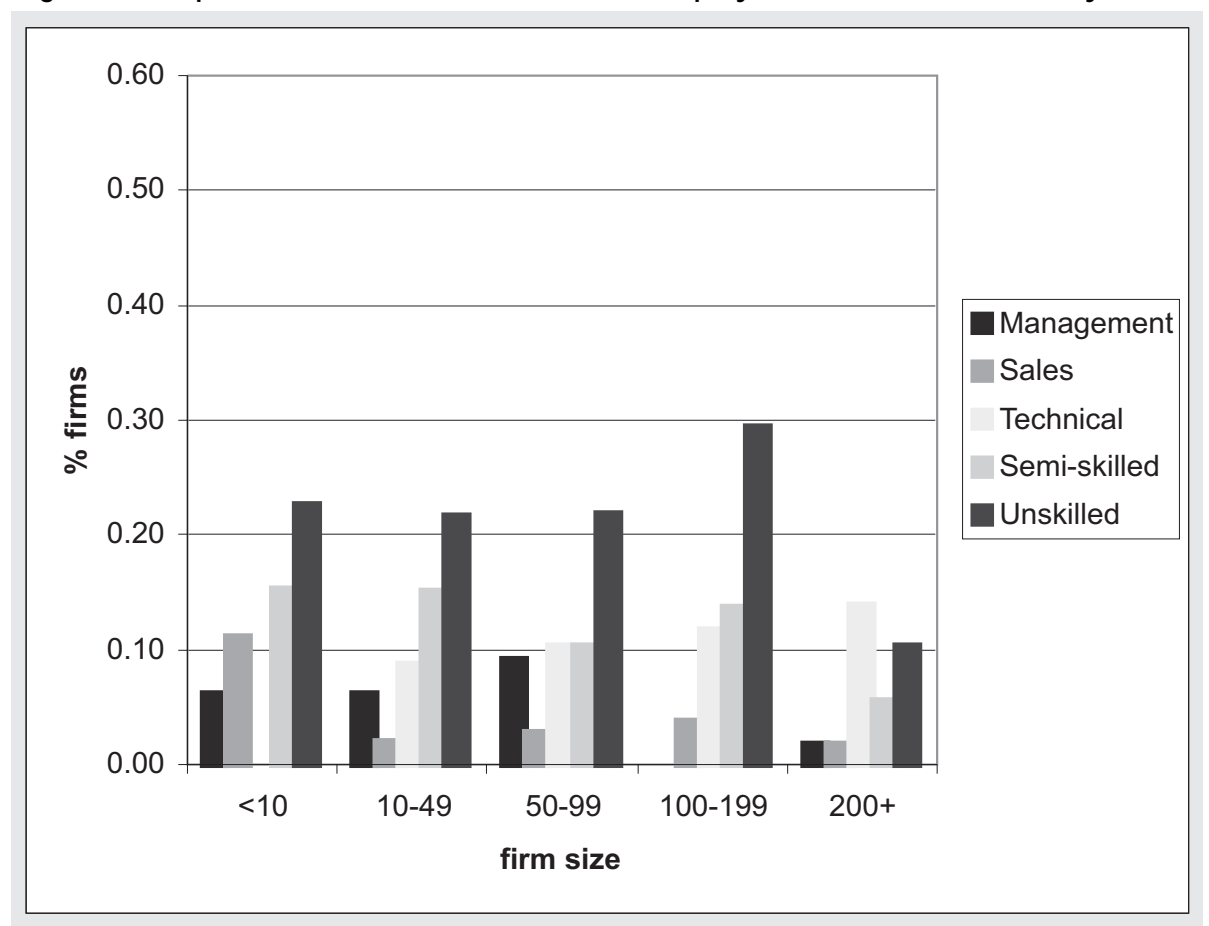

These results show that for the unskilled employed in small firms, changes in labour market regulations have been the most common reason for a decline in employment. For groups other than the unskilled, factors such as changes in market conditions are a more common reason given for declines in employment in these groups.

\subsection{How do Firms Respond to Labour Regulations?}

In the previous sub-section we found that particularly for firms with less than 200 employees the labour regulations were a common reason given for the decline in unskilled employment. In this sub-section we specifically investigate the response of firms to the employment regulations implemented in the 1990s. We use a question from the NES survey that asks how firms responded to the labour market regulations. Figure 11 illustrates these. 
Figure 11: The Response of Firms to the Labour Market Regulations. NES Survey

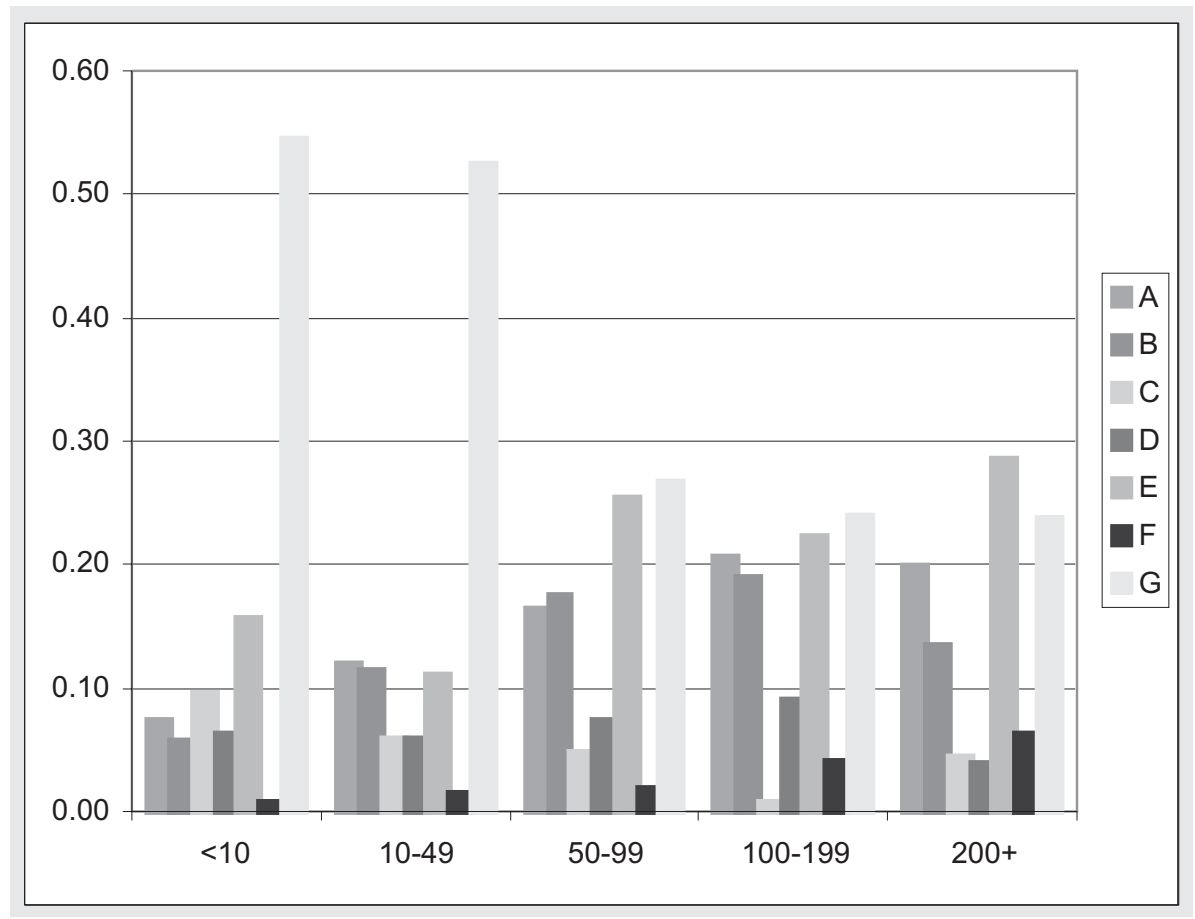

A - Reduced workforce by attrition

E-Increased outsourcing and sub-contracting

B - Replaced labour by machines

$\mathrm{F}$ - Other

C - Replaced full-time workers with part-time

$\mathrm{G}$ - No significant response

D - Replaced permanent employees with temporary 
The most common response to the implementation of the labour regulations has been to do nothing. This is particularly the case among smaller firms who may not be able to shed jobs. The next most common response is to increase sub-contracting and outsourcing. This is a more common response among larger firms than smaller firms. Reducing the workforce by attrition and replacing labour by machines are also common responses particularly by firms with more than 50 employees.

\subsection{Do Labour Regulations Affect Firm Growth?}

It seems that the negative consequences of the labour regulations fall particularly on the unskilled in smaller firms. In this sub-section we investigate whether we can identify any link between firm growth and labour regulations, and whether the impact on firm growth varies by size. The WB/GJMA survey asked for employment patterns over the period 1994-1998. This covers the period of implementation of the Labour Relations Act (LRA) in 1995, the Basic Conditions of Employment Act (BCEA) in 1997 and the Employment Equity Act (EEA) in 1998. The Skills Development Act (SDA) was implemented in 1999 and the survey also included a question on this. We are thus able to investigate how these Acts may have impacted on employment and firm growth.

Table 15: Firms Employment Response to the Various Labour Acts. WB/GJMA Survey

\begin{tabular}{|c|c|c|c|c|}
\hline & LRA & BCEA & EEA & SDA \\
\hline Raise employment & & & & \\
\hline Frequency & 8 & 10 & 16 & 14 \\
\hline$\%$ of total & 0.03 & 0.03 & 0.05 & 0.05 \\
\hline Lower employment & & & & \\
\hline Frequency & 87 & 69 & 66 & 43 \\
\hline $\begin{array}{c}\text { \% of total } \\
\text { No effect }\end{array}$ & 0.28 & 0.22 & 0.23 & 0.16 \\
\hline Frequency & 214 & 228 & 210 & 216 \\
\hline$\%$ of total & 0.70 & 0.74 & 0.72 & 0.79 \\
\hline Total & 309 & 307 & 292 & 273 \\
\hline
\end{tabular}

The responses indicate that more firms believe that the various Labour Acts have lead to a reduction in employment than an increase. Of the sample, 28 per cent believe that the LRA has resulted in the lowering of employment in their firm and only 3 per cent believe it has caused employment to rise. Twenty-two per cent of the sample believe that the BCEA has reduced employment and 23 per cent believe that this is the case for the EEA. However, about 70 per cent of firms believe that these Acts have had no effect on employment levels. 
In order to investigate whether the LRA, BCEA and EEA have impacted on firm growth we create a dummy variable which takes the value 1 if the firm believes that the Act has reduced employment and a value 0 if the firm believes it has had no effect or increased employment. We then model firm growth to investigate whether these specific labour acts had a significant impact.

We estimate the following equation:

$\Delta \ln (e m p)_{i t}=\alpha+\beta_{1} \ln \left(\right.$ size $\left._{i t}\right)+\beta_{2}$ labreg $_{i}+\beta_{3}\left(\ln \left(\right.\right.$ size $\left.\left._{i t}\right) \times \operatorname{labreg}_{i}\right)+\beta_{4} X_{i}+\varepsilon_{i t}$ where:

The dependent variable is the natural logarithm of the change in employment between any two (three) years;

size $_{i t}$ is the average size of the firm for the two (three) years;

labreg $_{i}$ is a dummy variable taking the value 1 if the firm reports that the labour act lead to a decrease in employment, and 0 otherwise;

$X_{i}$ is a vector of firm specific characteristics that includes the proportion of skilled and semi-skilled workers, whether the firms exports, whether it has foreign ownership and sector specific dummies.

The results for the LRA and BCEA are presented in Tables 16-17. We do not present estimates for the EEA as we find that this act did not have a significant effect on employment growth during this period. This may be because it was only implemented towards the end of the sample period. 
Table 16: Firm Growth and the LRA, OLS, WB/GJMA Survey

\begin{tabular}{|c|c|c|c|c|c|c|c|}
\hline & (1) & (2) & (3) & (4) & (5) & (6) & (7) \\
\hline & \multicolumn{4}{|c|}{$1^{\text {st }}$ differences } & \multicolumn{3}{|c|}{$2^{\text {nd }}$ differences } \\
\hline $\begin{array}{l}\text { In(employment } \\
\text { growth): }\end{array}$ & $94-95$ & $95-96$ & $96-97$ & $97-98$ & $94-96$ & $95-97$ & $96-98$ \\
\hline \multirow{2}{*}{ LRA affected } & 0.521 & 0.103 & -0.679 & -0.000 & 1.120 & -1.494 & -0.923 \\
\hline & $(1.78)^{*}$ & $(0.40)$ & $(1.67)^{\star}$ & $(0.00)$ & $(1.75)^{\star}$ & $(2.08)^{\star \star}$ & $(1.96)^{\star}$ \\
\hline \multirow{2}{*}{ In (ave emp) } & -0.013 & -0.042 & -0.101 & -0.033 & -0.047 & -0.287 & -0.168 \\
\hline & $(0.40)$ & $(1.48)$ & $(1.94)^{*}$ & $(1.64)$ & $(0.62)$ & $(3.36)^{\star \star \star}$ & $(2.76)^{\star \star \star}$ \\
\hline \multirow{2}{*}{$\begin{array}{l}\text { LRA affected } x \\
\text { In(ave emp) }\end{array}$} & -0.099 & -0.027 & 0.104 & -0.005 & -0.217 & 0.258 & 0.154 \\
\hline & $(1.69)^{*}$ & $(0.51)$ & $(1.31)$ & $(0.15)$ & $(1.69)^{\star}$ & $(1.78)^{\star}$ & $(1.66)^{*}$ \\
\hline \multirow{2}{*}{$\%$ skilled } & -0.169 & -0.196 & 0.024 & -0.221 & -0.559 & 0.246 & -0.377 \\
\hline & $(0.56)$ & $(0.76)$ & $(0.06)$ & $(1.74)^{*}$ & $(0.89)$ & $(0.37)$ & $(0.79)$ \\
\hline \multirow{2}{*}{$\%$ semiskilled } & -0.273 & 0.122 & 0.149 & 0.025 & -0.055 & 0.504 & 0.222 \\
\hline & $(2.43)^{\star \star}$ & $(1.29)$ & $(0.98)$ & $(0.44)$ & $(0.23)$ & $(2.03)^{\star \star}$ & (1.29) \\
\hline \multirow{2}{*}{$\begin{array}{l}\text { Foreign owned } \\
\text { dummy }\end{array}$} & 0.017 & -0.001 & -0.139 & -0.055 & -0.010 & -0.054 & -0.223 \\
\hline & $(0.25)$ & $(0.02)$ & $(1.59)$ & $(1.69)^{*}$ & $(0.07)$ & $(0.37)$ & $(2.24)^{\star *}$ \\
\hline \multirow{2}{*}{ Export dummy } & 0.034 & -0.031 & 0.014 & -0.023 & -0.127 & -0.074 & -0.047 \\
\hline & $(0.54)$ & $(0.61)$ & $(0.16)$ & $(0.76)$ & $(0.98)$ & $(0.54)$ & $(0.50)$ \\
\hline Sector controls & Yes & Yes & Yes & Yes & Yes & Yes & Yes \\
\hline Observations & 168 & 183 & 215 & 262 & 170 & 185 & 217 \\
\hline R-squared & 0.12 & 0.08 & 0.09 & 0.09 & 0.11 & 0.14 & 0.13 \\
\hline
\end{tabular}

Table 17: Firm Growth and the BCEA, OLS, WB/GJMA Survey

\begin{tabular}{|c|c|c|c|c|c|c|c|}
\hline & (1) & (2) & (3) & (4) & (5) & (6) & (7) \\
\hline & \multicolumn{4}{|c|}{$1^{\text {st }}$ differences } & \multicolumn{3}{|c|}{$2^{\text {nd }}$ differences } \\
\hline $\begin{array}{l}\text { In(employment } \\
\text { growth): }\end{array}$ & $94-95$ & $95-96$ & $96-97$ & $97-98$ & $94-96$ & $95-97$ & $96-98$ \\
\hline \multirow{2}{*}{ BCEA affected } & 0.317 & 0.083 & -0.914 & 0.017 & 0.883 & -1.586 & -1.261 \\
\hline & $(1.05)$ & $(0.40)$ & $(3.21)^{\star * *}$ & $(0.11)$ & $(1.41)$ & $(2.23)^{\star *}$ & $(3.24)^{* * *}$ \\
\hline \multirow{2}{*}{ In (ave emp) } & -0.020 & -0.040 & -0.143 & -0.036 & -0.051 & -0.303 & -0.210 \\
\hline & $(0.57)$ & $(1.73)^{\star}$ & $(3.90)^{\star \star \star *}$ & $(1.64)$ & $(0.68)$ & $(3.46)^{\star * \star}$ & $(4.13)^{\star \star \star}$ \\
\hline \multirow{2}{*}{$\begin{array}{l}\text { BCEA affected } x \\
\text { In(ave emp) }\end{array}$} & -0.061 & -0.018 & 0.159 & -0.006 & -0.157 & 0.270 & 0.223 \\
\hline & (1.04) & $(0.45)$ & $(2.89)^{\star \star \star}$ & $(0.18)$ & (1.29) & $(1.93)^{*}$ & $(2.95)^{\star \star \star}$ \\
\hline \multirow{2}{*}{$\%$ skilled } & -0.098 & -0.021 & 0.141 & -0.223 & -0.258 & 0.150 & -0.228 \\
\hline & $(0.32)$ & $(0.10)$ & $(0.49)$ & $(1.71)^{*}$ & $(0.42)$ & $(0.23)$ & $(0.59)$ \\
\hline \multirow{2}{*}{$\%$ semiskilled } & -0.293 & -0.003 & 0.201 & -0.012 & -0.207 & 0.457 & 0.226 \\
\hline & $(2.50)^{\star \star}$ & $(0.04)$ & $(1.93)^{*}$ & $(0.21)$ & $(0.88)$ & $(1.86)^{\star}$ & (1.63) \\
\hline \multirow{2}{*}{$\begin{array}{l}\text { Foreign owned } \\
\text { dummy }\end{array}$} & 0.012 & 0.026 & -0.051 & -0.037 & 0.011 & -0.008 & -0.120 \\
\hline & $(0.17)$ & $(0.60)$ & $(0.86)$ & $(1.14)$ & $(0.08)$ & $(0.06)$ & $(1.53)$ \\
\hline \multirow{2}{*}{ Export dummy } & 0.025 & -0.062 & -0.017 & -0.026 & -0.192 & -0.061 & -0.079 \\
\hline & $(0.39)$ & $(1.46)$ & $(0.28)$ & $(0.83)$ & $(1.48)$ & $(0.44)$ & (1.03) \\
\hline Sector controls & Yes & Yes & Yes & Yes & Yes & Yes & Yes \\
\hline Observations & 165 & 181 & 212 & 260 & 167 & 183 & 214 \\
\hline R-squared & 0.11 & 0.10 & 0.16 & 0.08 & 0.11 & 0.15 & 0.19 \\
\hline
\end{tabular}


The coefficient estimates for both the LRA and the BCEA follow a similar pattern: for 96-97, 95-97 and 96-98, those firms that claim to be affected by these regulations grew slower (or contracted faster) than unaffected firms; over the same periods larger firms that claimed to be affected by these regulations were less affected (i.e. grew at a faster rate, or contracted more slowly) than smaller firms.

The coefficient estimates from the first difference equation are then used to predict firm growth for firms of various sizes over the four years. ${ }^{7}$ Firm size is normalised to 100 in 1994 so as to be able to compare the percentage growth in employment across size groups. Figure 12 illustrate this.

Figure 12: Predicted Firm Growth for Firms that Report the LRA has Lowered Employment and those that Report it has had no Effect or Increased Employment

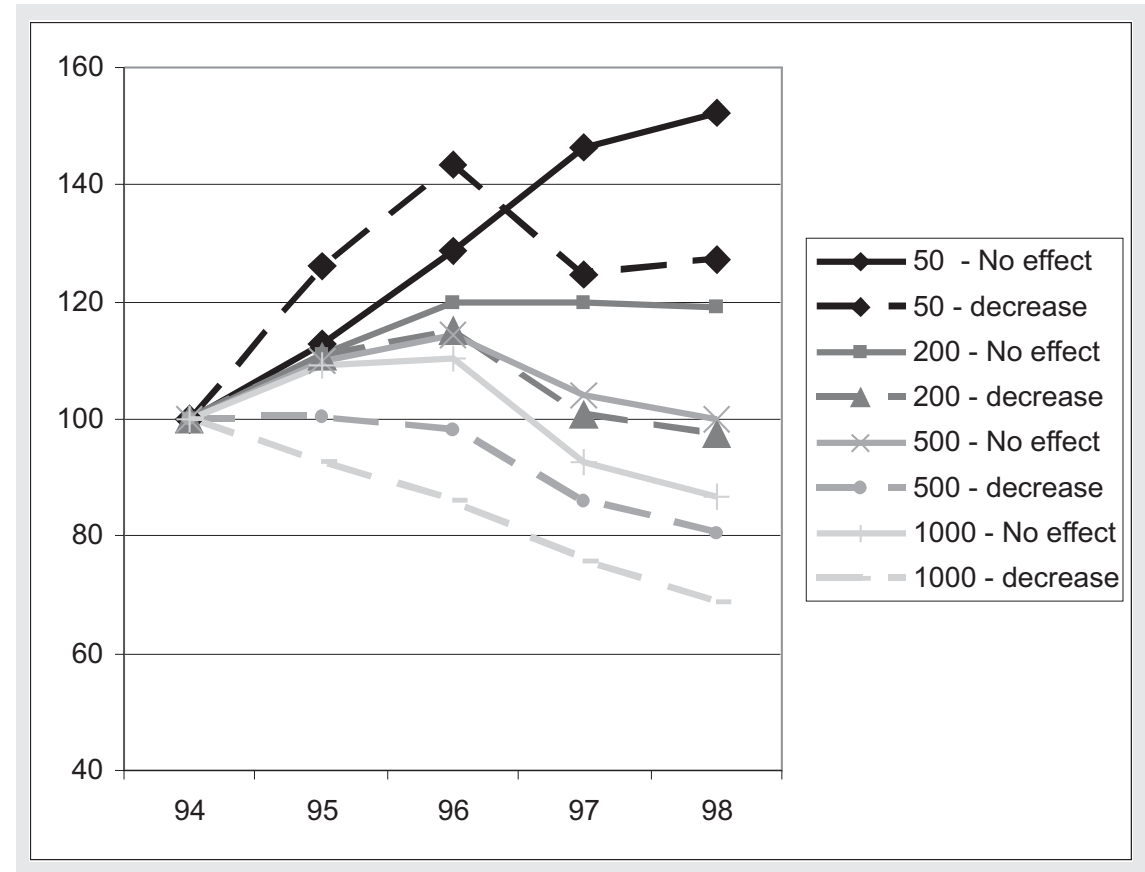

7 Using second differences produces a similar pattern. 
Those firms that report that the LRA has decreased employment have significantly different growth trajectories to those that report that the LRA had no effect or increased employment.

The impact of the LRA is largest for smaller firms (a 25 per cent difference in growth over four years for 50 employee firms compared to a 22 per cent difference for 200 employee firms, a 20 per cent difference for 500 employee firms, and an 18 per cent gap for 1000 employee firms). Smaller firms affected by the LRA seem to have grown faster than unaffected firms between 1994 and 1996. However, between 1996 and 1998 smaller LRA affected firms decreased employment whereas unaffected firms continued to grow. This change in growth patterns broadly corresponds with the implementation of the LRA in 1995.

Figure 13: Predicted Firm Growth for Firms that Report the BCEA has Lowered Employment and those that Report it has had no Effect or Increased Employment

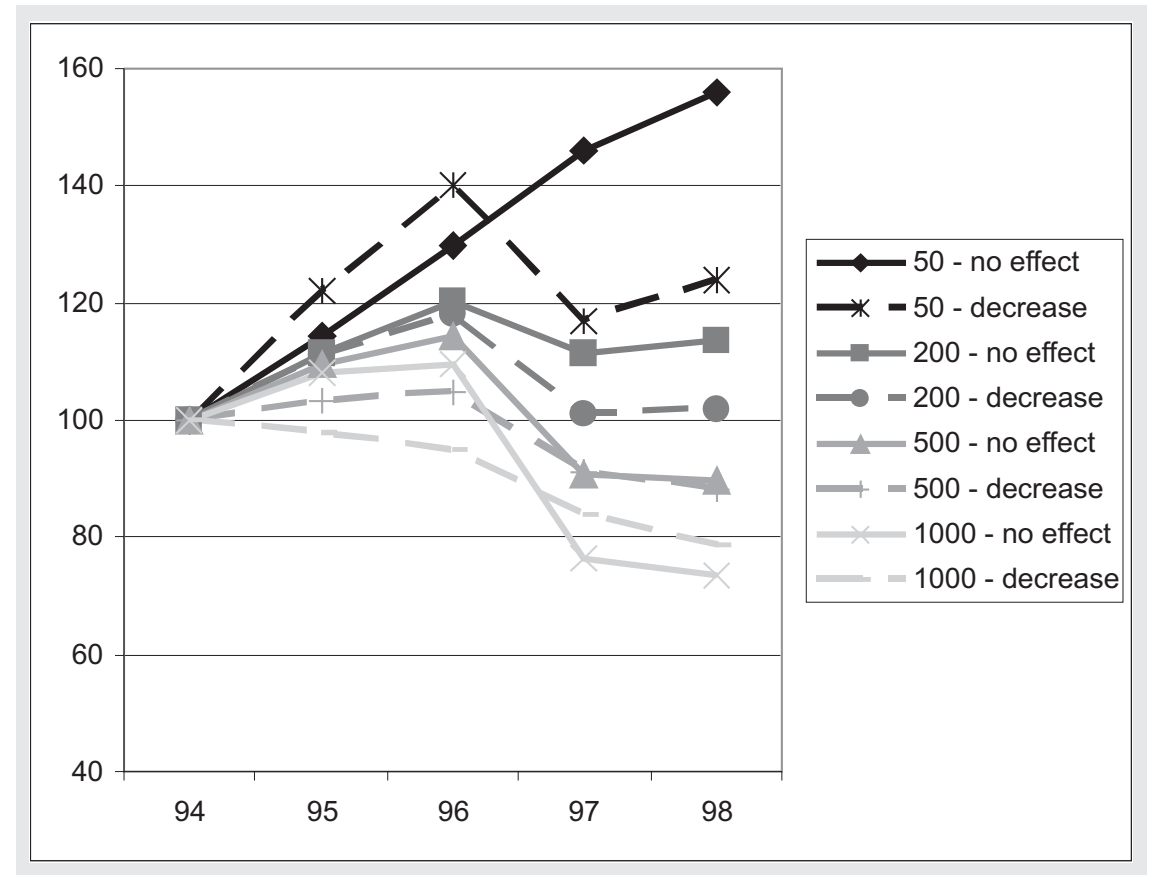

The estimated growth trajectories for the BCEA affected firms also indicate that this labour act constrained growth more for smaller firms than for larger firms. Fifty employee firms unaffected by the BCEA grew by 32 per cent more over the four years than affected firms. 
For 200 employee firms this gap was 12 per cent. The gap was only 1 per cent for 500 employee firms and for firms with 1000 employees those affected by BCEA actually grew by 5 per cent more than the unaffected.

For the employment equity act (EEA) and the skills development act (SDA) there is no significant difference in growth between those firms that claim to be negatively affected by these acts and other firms. However, these acts were very new when this survey took place and the impact of these on employment growth may not have been felt at the time of the survey.

\subsection{Which Parts of theLabourRregulations are Most Onerous to Firms?}

South African labour regulations cover a number of different areas. It is likely that some components of the regulations are more onerous to firms than others. In this sub-section we investigate how firms view the impact of the various components of the labour regulations on their decisions to hire new full-time employees and on production costs. We use a question from the NES to investigate this. 
Figure 14: Labour Regulations and Hiring New Employees: NES Survey

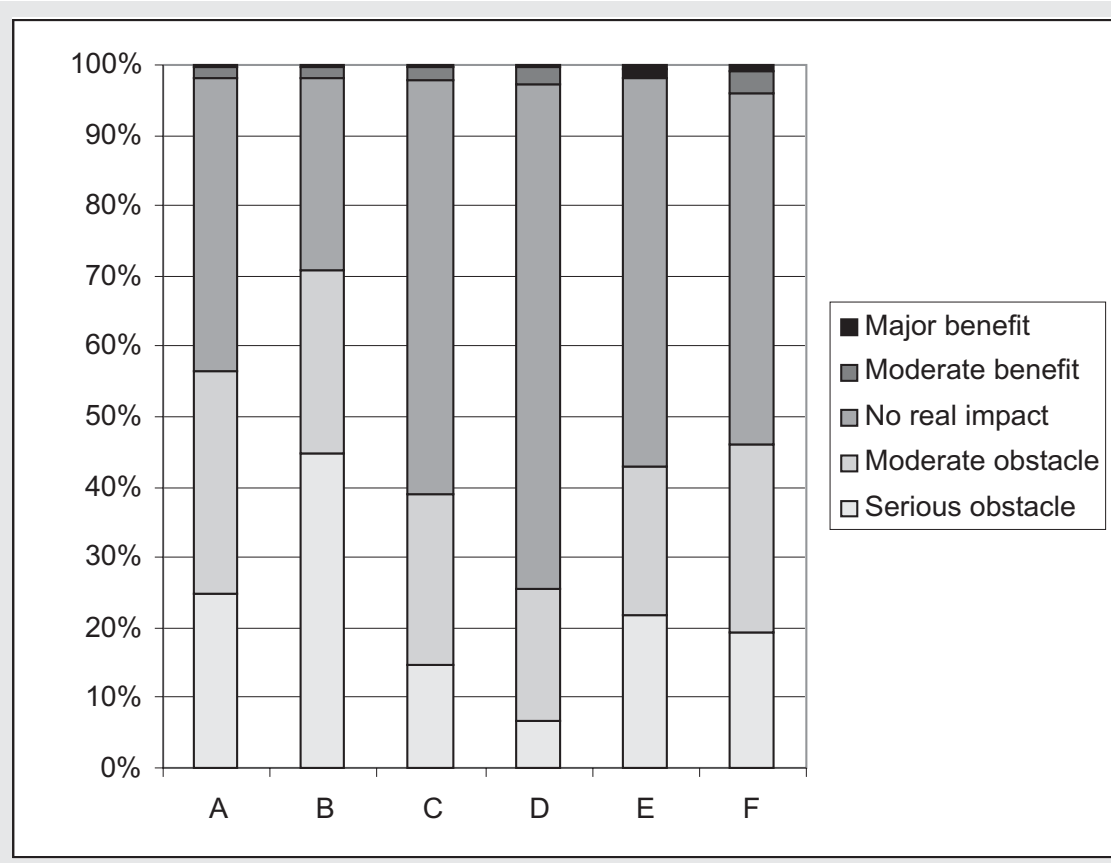

A - Hiring procedures;

B - Firing or dismissal procedures;

C - Working time (hours per week, overtime etc);
D - Leave provisions;

E - Rights to collective action (join unions, strike etc.);

$\mathrm{F}$ - Affirmative action provisions. 
Figure 15: Labour Regulations and the Costs of Production: NES Survey

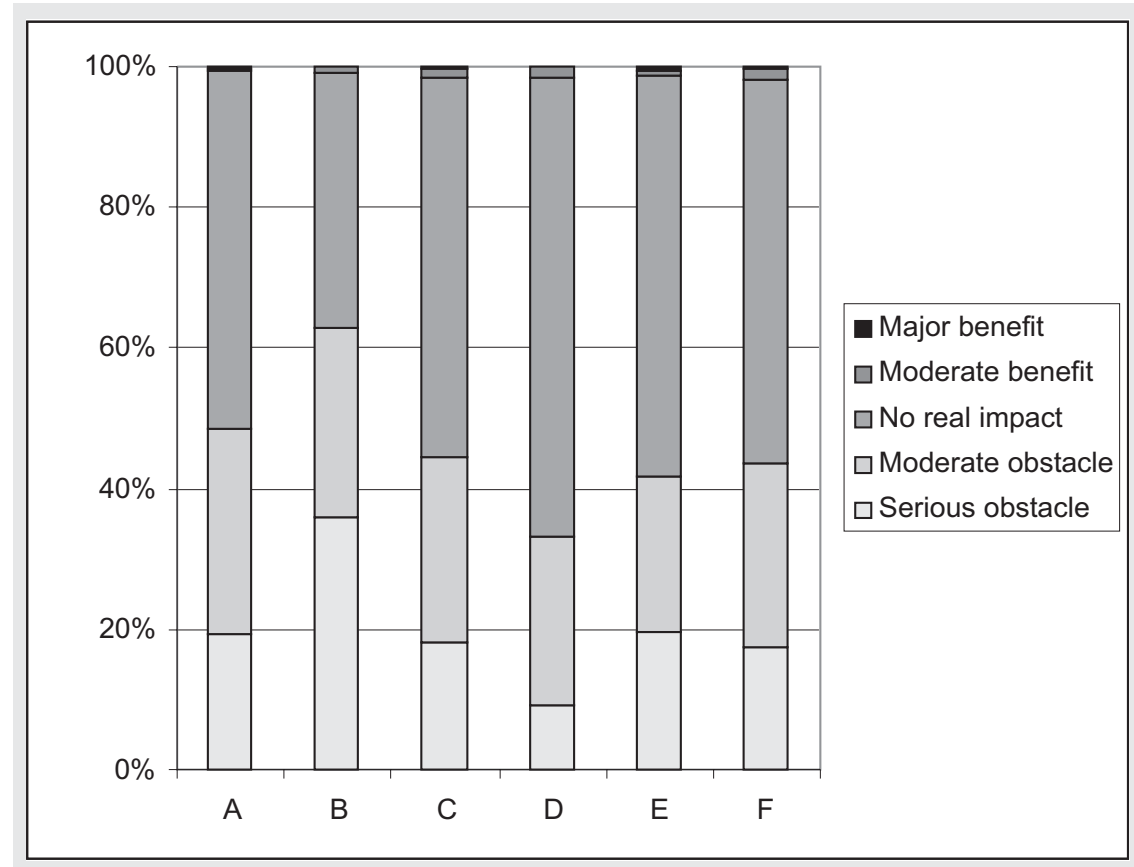

A - Hiring procedures;

B - Firing or dismissal procedures;

C - Working time (hours per week, overtime etc);
D - Leave provisions;

$\mathrm{E}-$ Rights to collective action (join unions, strike etc.);

$\mathrm{F}$ - Affirmative action provisions

The results suggest that the part of the labour regulations that most firms regard as a serious obstacle to hiring new staff and that affects production costs most are the firing and dismissal procedures. Seventy-one per cent of firms regard the firing procedures set out in the various acts as a moderate or serious obstacle to hiring new employees. This is in comparison to 57 per cent who believe that the hiring procedures restrict hiring and 46 per cent who believe affirmative action is a moderate or serious problem. Almost no firms view any of the components as a benefit. 


\subsection{Do Firms Perceive any Benefits to the Labour Regulations?}

There are of course benefits to the labour market regulations, particularly to those who have jobs and are covered by the regulations. On the firm side, benefits could include improved labour relations or productivity. In this sub-section we investigate whether firms perceive any benefits to labour market regulations.

Figure 16. Responses to: "In 1998, as a result of recent labour laws and regulations, did this establishment experience any of the following." NES survey

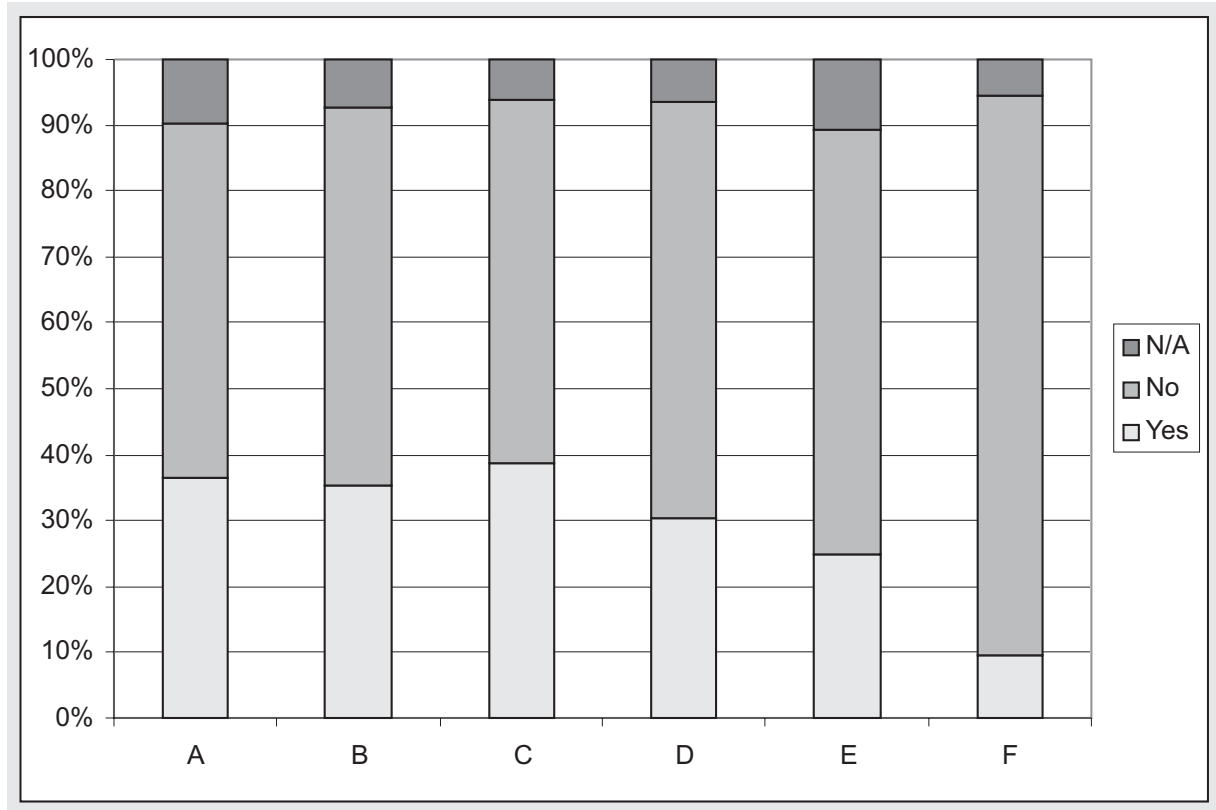

A - Hire fewer workers;

D - Rely on sub-contracting;

$B$ - Use more machinery instead of hiring

E - Saw labour relations improve in more labour to expand production; establishment;

$\mathrm{C}$ - Hire workers on a temporary rather than permanent basis;

$\mathrm{F}-$ Found an increase in labour productivity

As figure 16 illustrates, very few firms perceive that there has been any benefits to them from the labour regulations. Of the firms, 24 per cent felt that labour relations improved compared to 64 per cent who felt no improvement. Even fewer experienced an improvement in labour productivity. Only 9 per cent of the firms believed that the labour regulations lead to an improvement in productivity. 


\section{Trade regulations and SMMEs}

In many of the surveys examined, customs and trade regulation is the second or third most frequently mentioned major regulatory obstacle (see Table 6). This section examines the impact of trade regulations on SMMES more closely.

Since 1994 import tariffs have been reduced in many sectors. The NES asks a set of questions on how the cuts in import tariffs have affected firms. The answers to these questions are presented in Table 18. Forty-three per cent of firms have experienced lower input costs and 30 per cent lower equipment costs due to decreases in tariffs. There is little difference across size categories. 42 per cent of firms have lowered the price of their products as a result of lower import tariffs. Firms with less than 10 employees are more likely to have lowered prices than firms in other size categories.

The reduction in import tariffs has resulted in a loss of market share for 45 per cent of firms in the sample. Larger firms are more likely to have lost market share than smaller firms. The difference between small and large firms is dramatic. Only 31 per cent of firms with less than 50 employees report losing market share compared with 61 per cent of firms with more than 200 employees. It is likely that larger firms have higher price-cost mark-ups, due to increased market power, and thus this result is consistent with a robust result in other countries - trade liberalisation reduces price-cost mark-ups (see Tybout, 2003 , for a review of the evidence). This finding suggests that one way of dealing with the large price-cost mark-ups in South African industries (Fedderke, Kularatne, and Mariotti, 2003 ) is through increased trade liberalisation.

The reduction in input and equipment costs due to tariff liberalisation may lead to increased competitiveness of exports. Thirty-four per cent of firms claim this is the case, although there is little discernable pattern across size groups. 
Table 18: The Affect of Tariff Cuts on Firms, by Size, NES Survey

\begin{tabular}{|c|c|c|c|c|c|c|}
\hline \multicolumn{7}{|c|}{ Lower raw material costs } \\
\hline & $<10$ & $10-49$ & $50-99$ & $100-199$ & $200+$ & Total \\
\hline Significant & 0.10 & 0.09 & 0.10 & 0.06 & 0.09 & 0.09 \\
\hline Moderate & 0.36 & 0.34 & 0.34 & 0.35 & 0.34 & 0.34 \\
\hline None & 0.55 & 0.57 & 0.55 & 0.59 & 0.57 & 0.57 \\
\hline \multicolumn{7}{|c|}{ Lower equipment costs } \\
\hline & $<10$ & $10-49$ & $50-99$ & $100-199$ & $200+$ & Total \\
\hline Significant & 0.05 & 0.03 & 0.05 & 0.03 & 0.04 & 0.04 \\
\hline Moderate & 0.32 & 0.21 & 0.29 & 0.23 & 0.31 & 0.26 \\
\hline None & 0.63 & 0.76 & 0.67 & 0.74 & 0.65 & 0.70 \\
\hline \multicolumn{7}{|c|}{ Lower own product price } \\
\hline & $<10$ & $10-49$ & $50-99$ & $100-199$ & $200+$ & Total \\
\hline Significant & 0.18 & 0.12 & 0.12 & 0.14 & 0.12 & 0.13 \\
\hline Moderate & 0.34 & 0.24 & 0.30 & 0.29 & 0.33 & 0.29 \\
\hline None & 0.48 & 0.63 & 0.57 & 0.56 & 0.55 & 0.58 \\
\hline \multicolumn{7}{|c|}{ Loss of SA market share to foreign competitors } \\
\hline & $<10$ & $10-49$ & $50-99$ & $100-199$ & $200+$ & Total \\
\hline Significant & 0.13 & 0.14 & 0.27 & 0.18 & 0.23 & 0.19 \\
\hline Moderate & 0.18 & 0.17 & 0.26 & 0.28 & 0.38 & 0.26 \\
\hline None & 0.69 & 0.69 & 0.47 & 0.54 & 0.39 & 0.55 \\
\hline \multicolumn{7}{|c|}{ Made exports more competitive } \\
\hline & $<10$ & $10-49$ & $50-99$ & $100-199$ & $200+$ & Total \\
\hline Significant & 0.05 & 0.09 & 0.11 & 0.07 & 0.09 & 0.09 \\
\hline Moderate & 0.26 & 0.18 & 0.29 & 0.30 & 0.28 & 0.25 \\
\hline None & 0.68 & 0.73 & 0.59 & 0.63 & 0.63 & 0.66 \\
\hline
\end{tabular}

Evidence that trade liberalisation may benefit SMMEs is provided in Table 19. Firms were asked whether import tariffs were too high. Across all size groups a majority answered yes. However, among firms with less than 100 employees 64-69 per cent felt that tariffs were too high compared to $56-60$ per cent for firms with more than 100 employees. This is in line with results presented earlier that suggest that tariff liberalisation benefited smaller firms more than larger firms. 
Table 19: Are Import Tariffs too High? NES Survey, by Size, \% of Firms

\begin{tabular}{|l|c|c|c|c|c|c|}
\hline & $<10$ & $10-49$ & $50-99$ & $100-199$ & $200+$ & Total \\
\hline Yes & 0.65 & 0.64 & 0.69 & 0.60 & 0.56 & 0.62 \\
\hline No & 0.35 & 0.36 & 0.31 & 0.40 & 0.44 & 0.38 \\
\hline
\end{tabular}

Table 20 presents further evidence that existing import tariffs benefit larger firms. Twenty per cent of firms with more than 200 employees perceive import barriers as a benefit to them, compared with just 9 per cent of firms with less than 10 employees, and 12 per cent of firms with 10-49 employees. However, not all larger firms view import barriers as a benefit. Fifteen per cent of large firms report that these are an obstacle to their business. This proportion is similar across size groups. This is again in line with international evidence reviewed by Tybout (2003) - trade liberalisation reduces the size of import competing firms in industries with large barriers to entry (the types of industries which would be dominated by large firms) but has little effect on firms in industries where entry is easy (the types of industries where small firms would be common).

The costs and delays associated with clearing imports, as well as the improper application of import regulations is more likely to be an obstacle to larger firms. An explanation for this is that larger firms are more likely to import ${ }^{8}$ and thus more likely to bear the costs associated with importing.

A similar explanation can be given for why larger firms find South African export regulations and foreign barriers to entry more onerous than smaller firms - larger firms are more likely to export than smaller firms. ${ }^{9}$

8 The following table gives the proportion of firms within each size category that import.

$\begin{array}{rrrrr}<10 & 10-49 & 50-99 & 100-199 & 200+ \\ 0.44 & 0.50 & 0.58 & 0.72 & 0.81\end{array}$

9 The following table gives the proportion of firms in each size group that export.

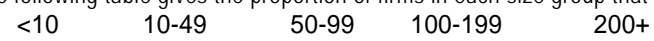

$\begin{array}{lllll}0.20 & 0.26 & 0.49 & 0.54 & 0.71\end{array}$ 
Table 20: The Impact of Aspects of Import and Export Regulation on Operations, by Size, NES Survey, \% of Firms

\begin{tabular}{|c|c|c|c|c|c|c|}
\hline \multicolumn{7}{|c|}{ SA anti-dumping action } \\
\hline & $<10$ & $10-49$ & $50-99$ & $100-199$ & $200+$ & Total \\
\hline Obstacle & 0.17 & 0.23 & 0.13 & 0.19 & 0.23 & 0.20 \\
\hline None & 0.65 & 0.60 & 0.59 & 0.64 & 0.51 & 0.59 \\
\hline Benefit & 0.17 & 0.18 & 0.28 & 0.17 & 0.26 & 0.22 \\
\hline \multicolumn{7}{|c|}{ Licences or other barriers limiting access to imports } \\
\hline & $<10$ & $10-49$ & $50-99$ & $100-199$ & $200+$ & Total \\
\hline Obstacle & 0.15 & 0.21 & 0.16 & 0.25 & 0.15 & 0.19 \\
\hline None & 0.76 & 0.66 & 0.69 & 0.61 & 0.66 & 0.67 \\
\hline Benefit & 0.09 & 0.12 & 0.15 & 0.13 & 0.20 & 0.14 \\
\hline \multicolumn{7}{|c|}{ Costs of clearing imports through SA customs } \\
\hline & $<10$ & $10-49$ & $50-99$ & $100-199$ & $200+$ & Total \\
\hline Obstacle & 0.46 & 0.48 & 0.50 & 0.59 & 0.58 & 0.52 \\
\hline None & 0.54 & 0.52 & 0.50 & 0.41 & 0.42 & 0.48 \\
\hline \multicolumn{7}{|c|}{ Delays of clearing imports through SA customs } \\
\hline & $<10$ & $10-49$ & $50-99$ & $100-199$ & $200+$ & Total \\
\hline Obstacle & 0.48 & 0.51 & 0.57 & 0.66 & 0.63 & 0.57 \\
\hline None & 0.52 & 0.49 & 0.43 & 0.34 & 0.37 & 0.43 \\
\hline \multicolumn{7}{|c|}{ Improper application of tariff and custom rules by SA officials } \\
\hline & $<10$ & $10-49$ & $50-99$ & $100-199$ & $200+$ & Total \\
\hline Obstacle & 0.33 & 0.41 & 0.35 & 0.47 & 0.52 & 0.43 \\
\hline None & 0.67 & 0.59 & 0.65 & 0.53 & 0.48 & 0.57 \\
\hline \multicolumn{7}{|c|}{ SA regulations affecting export shipments } \\
\hline & $<10$ & $10-49$ & $50-99$ & $100-199$ & $200+$ & Total \\
\hline Obstacle & 0.20 & 0.23 & 0.22 & 0.29 & 0.31 & 0.25 \\
\hline None & 0.80 & 0.77 & 0.78 & 0.71 & 0.69 & 0.75 \\
\hline \multicolumn{7}{|c|}{ Foreign tariffs } \\
\hline & $<10$ & $10-49$ & $50-99$ & $100-199$ & $200+$ & Total \\
\hline Obstacle & 0.36 & 0.41 & 0.38 & 0.41 & 0.53 & 0.43 \\
\hline None & 0.64 & 0.59 & 0.62 & 0.59 & 0.47 & 0.57 \\
\hline \multicolumn{7}{|c|}{ Foreign licenses or other entry barriers } \\
\hline & $<10$ & $10-49$ & $50-99$ & $100-199$ & $200+$ & Total \\
\hline Obstacle & 0.29 & 0.28 & 0.31 & 0.32 & 0.45 & 0.33 \\
\hline None & 0.71 & 0.72 & 0.69 & 0.68 & 0.55 & 0.67 \\
\hline
\end{tabular}

The ICA survey asked a series of questions about the length of time it takes for imports and exports to clear customs. The median value for exports is about half that of imports. The longest period for goods to clear, for both exports and imports, is about double that of the average time goods take to clear. There is little difference in time across size groups. This result is not surprising given that there should be little reason why the time taken for goods to clear customs should vary with firm size. 


\section{Table 21: The Time taken to Clear Customs, by Size, ICA Survey}

\begin{tabular}{|c|c|c|c|c|c|}
\hline \multicolumn{6}{|c|}{$\begin{array}{l}\text { Average number of days between imports arriving at point of entry and time available to } \\
\text { claim. }\end{array}$} \\
\hline & $<50$ & $50-99$ & $100-199$ & $200+$ & Total \\
\hline mean & 6.01 & 6.73 & 8.46 & 6.19 & 6.77 \\
\hline median & 5 & 7 & 5 & 5 & 5 \\
\hline std dev & 5.05 & 4.47 & 13.86 & 5.84 & 7.86 \\
\hline $\mathrm{n}$ & 75 & 109 & 85 & 142 & 411 \\
\hline \multicolumn{6}{|c|}{$\begin{array}{l}\text { Longest number of days between imports arriving at point of entry and time available to } \\
\text { claim. }\end{array}$} \\
\hline & $<50$ & $50-99$ & 100-199 & $200+$ & Total \\
\hline mean & 10.81 & 12.02 & 17.05 & 11.97 & 12.83 \\
\hline median & 10 & 10 & 10 & 10 & 10 \\
\hline std dev & 8.10 & 10.38 & 40.21 & 9.08 & 20.19 \\
\hline $\mathrm{n}$ & 74 & 108 & 85 & 140 & 407 \\
\hline \multicolumn{6}{|c|}{$\begin{array}{l}\text { Average number of days between exports arriving at point of exit and time they cleared } \\
\text { customs }\end{array}$} \\
\hline & $<50$ & $50-99$ & $100-199$ & $200+$ & Total \\
\hline mean & 5.33 & 5.21 & 4.85 & 4.32 & 4.84 \\
\hline median & 3 & 5 & 3 & 3 & 3 \\
\hline std dev & 7.02 & 4.90 & 6.44 & 3.74 & 5.32 \\
\hline$n$ & 60 & 90 & 73 & 125 & 348 \\
\hline \multicolumn{6}{|c|}{$\begin{array}{l}\text { Longest number of days between exports arriving at point of exit and time they cleared } \\
\text { customs }\end{array}$} \\
\hline & $<50$ & $50-99$ & $100-199$ & $200+$ & Total \\
\hline mean & 8.24 & 7.69 & 7.99 & 7.61 & 7.82 \\
\hline median & 6 & 7 & 5 & 5 & 6 \\
\hline std dev & 10.52 & 5.72 & 7.55 & 6.37 & 7.32 \\
\hline $\mathrm{n}$ & 59 & 88 & 72 & 125 & 344 \\
\hline
\end{tabular}




\section{Licences and Permits}

Another area where government regulation affects firms is through the licences and permits firms require to start, expand and continue operations. Although many firms do not regard these as a serious obstacle to doing business in South Africa increasing the efficiency of the granting of these should benefit existing firms and may encourage firm entry.

Table 22 presents data from the ICA giving the number of days required between applying and being granted various licenses or connections to services. The wait for telephone, electrical and water connections are included in the table to place the waits for permits and licences into perspective. There is little difference across size categories in the time taken for the permits and licenses to be granted. ${ }^{10}$ In fact, the time taken to be granted construction permits and import and operating licenses is shorter than to be connected to telephones, electricity or water.

10 Again we look at the median to avoid the results being skewed by outlying values. 
Table 22: Number of Days Wait for Service, by Size, ICA Survey

\begin{tabular}{|c|c|c|c|c|c|}
\hline \multicolumn{6}{|c|}{ A mainline telephone connection } \\
\hline & $<50$ & $50-99$ & $100-199$ & $200+$ & Total \\
\hline mean & 6.98 & 10.66 & 5.51 & 7.40 & 8.01 \\
\hline median & 7 & 5 & 5 & 5 & 5 \\
\hline std dev & 6.47 & 45.10 & 4.06 & 8.40 & 26.20 \\
\hline $\mathrm{n}$ & 60 & 77 & 43 & 58 & 238 \\
\hline \multicolumn{6}{|c|}{ An electrical connection } \\
\hline & $<50$ & $50-99$ & $100-199$ & $200+$ & Total \\
\hline mean & 7.38 & 5.04 & 4.32 & 7.80 & 6.14 \\
\hline median & 4 & 4.5 & 4 & 4 & 4 \\
\hline std dev & 14.34 & 3.35 & 3.85 & 14.01 & 10.13 \\
\hline $\mathrm{n}$ & 45 & 70 & 34 & 50 & 199 \\
\hline \multicolumn{6}{|c|}{ A water connection } \\
\hline & $<50$ & $50-99$ & $100-199$ & $200+$ & Total \\
\hline mean & 6.14 & 4.26 & 2.91 & 4.44 & 4.43 \\
\hline median & 4 & 4 & 3 & 3 & 4 \\
\hline std dev & 14.81 & 2.59 & 2.36 & 6.81 & 7.62 \\
\hline $\mathrm{n}$ & 35 & 65 & 33 & 45 & 178 \\
\hline \multicolumn{6}{|c|}{ A construction permit } \\
\hline & $<50$ & $50-99$ & $100-199$ & $200+$ & Total \\
\hline mean & 15.17 & 8.20 & 7.29 & 7.82 & 8.76 \\
\hline median & 3.5 & 2 & 3 & 2 & 2 \\
\hline std dev & 29.34 & 20.99 & 19.38 & 19.87 & 21.32 \\
\hline $\mathrm{n}$ & 12 & 35 & 21 & 28 & 96 \\
\hline \multicolumn{6}{|c|}{ An import licence } \\
\hline & $<50$ & $50-99$ & $100-199$ & $200+$ & Total \\
\hline mean & 11.35 & 3.73 & 5.24 & 10.24 & 7.08 \\
\hline median & 3 & 2.5 & 2 & 2 & 2 \\
\hline std dev & 34.97 & 7.83 & 16.41 & 19.74 & 19.52 \\
\hline $\mathrm{n}$ & 26 & 60 & 29 & 45 & 160 \\
\hline \multicolumn{6}{|c|}{ Operating licence } \\
\hline & $<50$ & $50-99$ & $100-199$ & $200+$ & Total \\
\hline mean & 4.67 & 2.84 & 10.74 & 4.05 & 5.05 \\
\hline median & 3 & 3 & 2 & 2 & 3 \\
\hline std dev & 11.85 & 2.33 & 35.18 & 8.06 & 17.12 \\
\hline $\mathrm{n}$ & 24 & 58 & 31 & 40 & 153 \\
\hline
\end{tabular}

In the WB/GJMA survey firms were asked to comment on whether they believed that the number of permits required to continue operations were reasonable or excessive. Only 15 per cent responded that the number required was excessive. Firms in the 100-199 size group are the most satisfied with the number of permits required, those in the smaller size 
group and in the 200+ group are more likely to say that the required authorisations are excessive. A similar question was asked about the permits required to start a business. Here slightly more firms (18 per cent) answered that the number required was excessive. Again, more firms in the 40-99 size group and the 200+ size group thought the number of licences required was excessive than in the 100-199 size group.

For both continued operation and start-up the costs in terms of time are viewed as more excessive than the actual money costs. 11 Time costs for continuing operations are similar across size categories but the money costs are larger for small firms. For start-up, money costs are similar across categories but time costs are larger for smaller firms.

Table 23: Permits and Licences Required to Continue Operation, by Size, WB/GJMA Survey

\begin{tabular}{|c|c|c|c|c|}
\hline & $40-99$ & $100-199$ & $200+$ & Total \\
\hline Excessive number & 0.15 & 0.09 & 0.19 & 0.15 \\
\hline Reasonable number & 0.85 & 0.91 & 0.81 & 0.85 \\
\hline $\mathrm{n}$ & 73 & 43 & 62 & 178 \\
\hline \multicolumn{5}{|l|}{ Are time costs? } \\
\hline & $40-99$ & $100-199$ & $200+$ & Total \\
\hline Very costly & 0.26 & 0.26 & 0.23 & 0.25 \\
\hline Reasonable & 0.46 & 0.48 & 0.55 & 0.50 \\
\hline Not Costly & 0.28 & 0.26 & 0.22 & 0.25 \\
\hline$n$ & 69 & 42 & 60 & 171 \\
\hline \multicolumn{5}{|l|}{ Are money costs } \\
\hline & $40-99$ & $100-199$ & $200+$ & Total \\
\hline Very costly & 0.18 & 0.10 & 0.10 & 0.13 \\
\hline Reasonable & 0.50 & 0.60 & 0.63 & 0.57 \\
\hline Not Costly & 0.32 & 0.31 & 0.27 & 0.30 \\
\hline$n$ & 68 & 42 & 59 & 169 \\
\hline \multicolumn{5}{|c|}{ What is the worst constraint? } \\
\hline & $40-99$ & $100-199$ & $200+$ & Total \\
\hline Time costs & 0.33 & 0.30 & 0.42 & 0.35 \\
\hline Money (Rand costs) & 0.04 & 0.00 & 0.05 & 0.03 \\
\hline Neither/N/A & 0.59 & 0.63 & 0.48 & 0.57 \\
\hline Both & 0.05 & 0.07 & 0.05 & 0.05 \\
\hline $\mathrm{n}$ & 126 & 70 & 83 & 279 \\
\hline
\end{tabular}

11 Costs of regulation will be specifically examined in a later section. 
Table 24: Permits and Licences Required to Start-up Operations, by Size, WB/GJMA

\section{Survey}

Are the number of licences, permits and other authorisations to startup operation reasonable?

\begin{tabular}{|l|c|c|c|c|}
\hline & $40-99$ & $100-199$ & $200+$ & Total \\
\hline Excessive number & 0.19 & 0.11 & 0.23 & 0.18 \\
\hline Reasonable number & 0.81 & 0.89 & 0.77 & 0.82 \\
\hline $\mathrm{N}$ & 64 & 38 & 43 & 145 \\
\hline Are time costs? & $40-99$ & $100-199$ & $200+$ & Total \\
\hline \multicolumn{5}{|l|}{} \\
\hline Very costly & 0.38 & 0.31 & 0.29 & 0.34 \\
\hline Reasonable & 0.33 & 0.39 & 0.54 & 0.41 \\
\hline Not Costly & 0.29 & 0.31 & 0.17 & 0.26 \\
\hline $\mathrm{n}$ & 63 & 36 & 41 & 140 \\
\hline Are money costs & $40-99$ & $100-199$ & $200+$ & Total \\
\hline \multicolumn{7}{|l|}{} & 0.15 & 0.11 & 0.16 & 0.14 \\
\hline Very costly & 0.51 & 0.44 & 0.58 & 0.51 \\
\hline Reasonable & 0.34 & 0.44 & 0.26 & 0.34 \\
\hline Not Costly & 61 & 36 & 43 & 140 \\
\hline $\mathrm{n}$ & & & \\
\hline
\end{tabular}




\section{Other Aspects of Regulation}

This section covers aspects of regulation not covered in previous sections. These include: the costs of hiring expatriate staff; the consistency of regulatory enforcement; the unwieldiness of procedures; and the time spent in meetings associated with regulations.

\subsection{Immigration Regulations and Hiring Expatriate Staff}

One of the major constraints to business mentioned in both the WB/GJMA survey and the ICA was a lack of skilled workers. A short-term solution to this constraint is to hire foreigners with the requisite skills. Onerous immigration regulations may prevent firms from doing this. To examine this in more detail Table 25 presents the proportion of firms hiring expatriates and the costs in terms of time delays and money.

Table 25: The Costs of Hiring Expatriates, by Size, ICA Survey

\begin{tabular}{|c|c|c|c|c|c|}
\hline \multicolumn{6}{|c|}{$\%$ of firms hiring expatriate staff } \\
\hline & $<50$ & $50-99$ & 100-199 & $200+$ & Total \\
\hline mean & 0.09 & 0.13 & 0.18 & 0.18 & 0.15 \\
\hline median & 0 & 0 & 0 & 0 & 0 \\
\hline$n$ & 160 & 147 & 114 & 170 & 591 \\
\hline \multicolumn{6}{|c|}{$\%$ of expatriates hired (all firms) } \\
\hline & $<50$ & $50-99$ & 100-199 & $200+$ & Total \\
\hline mean & 0.96 & 1.76 & 1.65 & 1.05 & 1.32 \\
\hline median & 0 & 0 & 0 & 0 & 0 \\
\hline std dev & 5.69 & 9.36 & 9.91 & 3.54 & 7.27 \\
\hline $\mathrm{n}$ & 160 & 147 & 114 & 170 & 591 \\
\hline \multicolumn{6}{|c|}{$\%$ of expatriates hired (expatriate hiring firms only) } \\
\hline & $<50$ & $50-99$ & $100-199$ & $200+$ & Total \\
\hline mean & 10.24 & 13.63 & 8.95 & 5.75 & 9.06 \\
\hline median & 5 & 5 & 2 & 3 & 4 \\
\hline std dev & 16.29 & 23.23 & 22.05 & 6.54 & 17.22 \\
\hline $\mathrm{n}$ & 15 & 19 & 21 & 31 & 86 \\
\hline \multicolumn{6}{|c|}{ Time to hire an expatriate (days) } \\
\hline & $<50$ & $50-99$ & $100-199$ & $200+$ & Total \\
\hline mean & 28.58 & 21.65 & 28.56 & 45.26 & 31.63 \\
\hline median & 21 & 20 & 18 & 21 & 21 \\
\hline std dev & 25.72 & 15.27 & 29.01 & 56.89 & 38.33 \\
\hline $\mathrm{n}$ & 19 & 46 & 18 & 42 & 125 \\
\hline \multicolumn{6}{|c|}{ Cost to obtain expatriate visa $(R)$} \\
\hline & $<50$ & $50-99$ & $100-199$ & $200+$ & Total \\
\hline mean & 12,618 & 17,951 & 10,529 & 11,681 & 13,944 \\
\hline median & 15,000 & 18,000 & 12,000 & 7,500 & 15,000 \\
\hline std dev & 8,554 & 7,563 & 8,298 & 10,817 & 9,419 \\
\hline $\mathrm{n}$ & 17 & 41 & 17 & 37 & 112 \\
\hline
\end{tabular}


As the table illustrates, larger firms are more likely to hire expatriates. However, expatriates are a larger proportion of the permanent workforce in smaller firms, if non-expatriate hiring firms are excluded.

The time to hire an expatriate is constant across size groups (if we look at the median), however, the cost is larger for small firms. The median cost to hire an expatriate worker for a firm with less than 50 employees is double the median cost of hiring an expatriate worker for a firm with 200 or more employees. This may be why fewer small firms hire expatriates.

\subsection{The Consistency, Predictability and Application of Regulations}

Inconsistency in the application of regulations can have negative effects on firms by discouraging investment and firm growth. Figure 17 presents responses to the question "In general, government officials' interpretation of regulations affecting my establishment are consistent and predictable" in the ICA survey.

Firm responses are almost evenly split between those that feel that regulation interpretation is consistent and predictable and those that do not. Slightly more firms in the smallest and largest categories believe interpretation is not consistent and predictable than firms in the middle two size categories. 
Figure 17: "In general, government officials' interpretation of regulations affecting my establishment are consistent and predictable." ICA Survey

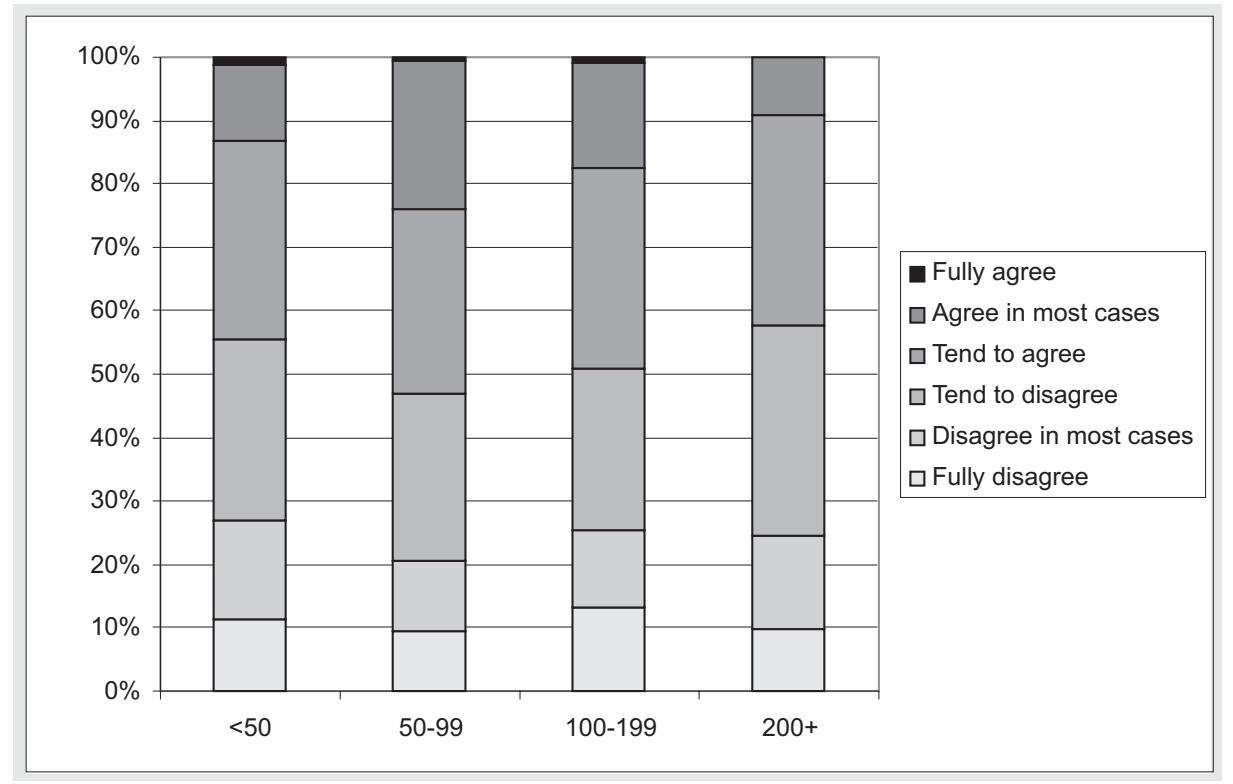

\subsection{Which Government Departments have the most Cumbersome Procedures?}

A regulation may not be burdensome in itself, but the bureaucratic process to comply with it may be unwieldy. The WB/GJMA survey asks respondents to identify which government department has the most cumbersome procedures. Among firms in the 40-99 size group and the $200+$ size group the Department of Labour and the local authorities are most often mentioned. The DTI and the local authorities are most often mentioned in the 100-199 size group. The departments of health and finance are the least mentioned departments. This question captures two effects. Firstly, the number of regulations associated with the department, and secondly, the burden of complying with the regulations. From this question it is difficult to distinguish whether a department has few regulations that are particularly burdensome, or many regulations that individually may not be a burden but cumulatively add up. 
Figure 18: Cumbersome Procedures by Department and Size. WB/GJMA Survey. Number of Firms Selecting that Department (Multiple Answers Allowed)

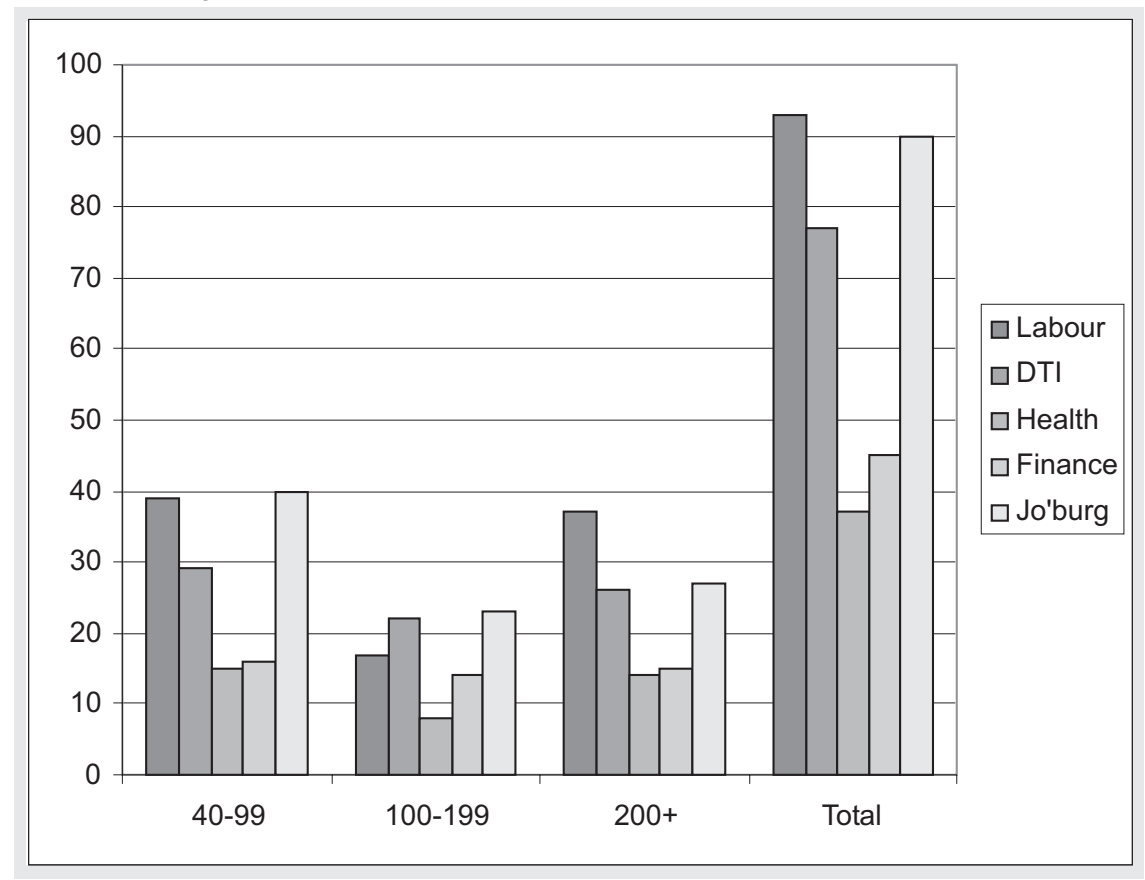

We next look at which departments expected bribes. If regulations are costly to meet, either because the process is burdensome or if it is expensive to comply with the regulations, then an incentive will exist for firms to pay bribes to circumvent the regulations. The Johannesburg local authority is the most often mentioned department where bribes are expected. This links with the fact that firms find the procedures of the local authority the most cumbersome. The Department of Labour is the second most mentioned department where bribes are expected.

It must be stressed that bribes are not common within any of the samples. Only 17 firms mentioned that the Johannesburg local authorities expected bribes, in comparison to 90 firms that mentioned that the local authority had cumbersome procedures. This is 19 per cent of the firms that found the procedures cumbersome but only 5 per cent of the sample. 
In the ICA data, only two firms (0.42 per cent of the sample) reported that bribes were expected when meeting with regulatory agencies. This illustrates that in South Africa bribes are very uncommon when doing business.

Figure 19: Bribes by Department and Size. WB/GJMA Survey. Number of Firms Selecting that Department (Multiple Answers Allowed)

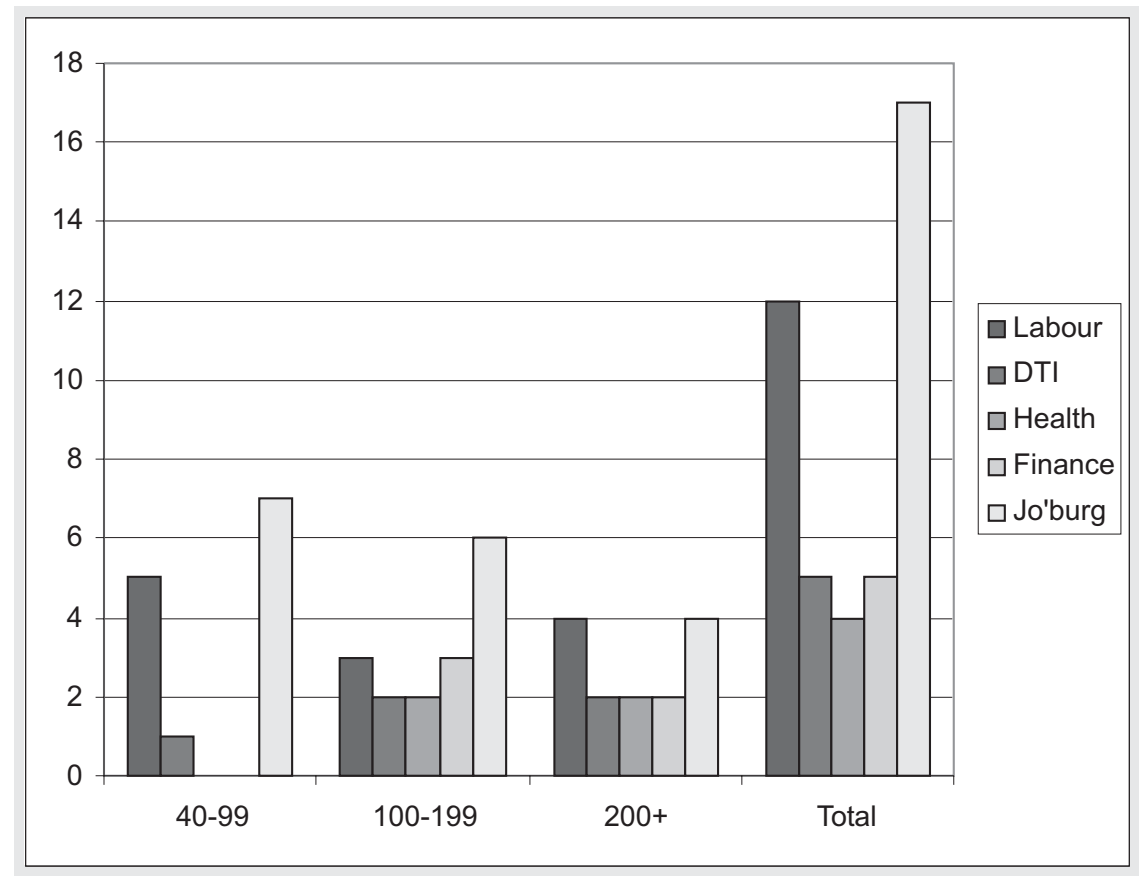

\subsection{Time in Meetings about Regulations}

The time spent in meetings about regulations can be a constraint to business. The ICA asked a set of questions about this. These results are presented in Figure 20. The median total number of days spent in meeting is highest among the 50-99 employee category. Smaller firms spend very little time in meetings but this increases sharply when they become larger than 50 employees. The tax inspectorate and labour and social security are the agencies where most days are spent. The number of days spent with these agencies is similar across all size groups except firms with less than 50 employees. 
Figure 20: Median Number of Days Spent in Inspections and Required Meetings With Officials, by Size. ICA Survey

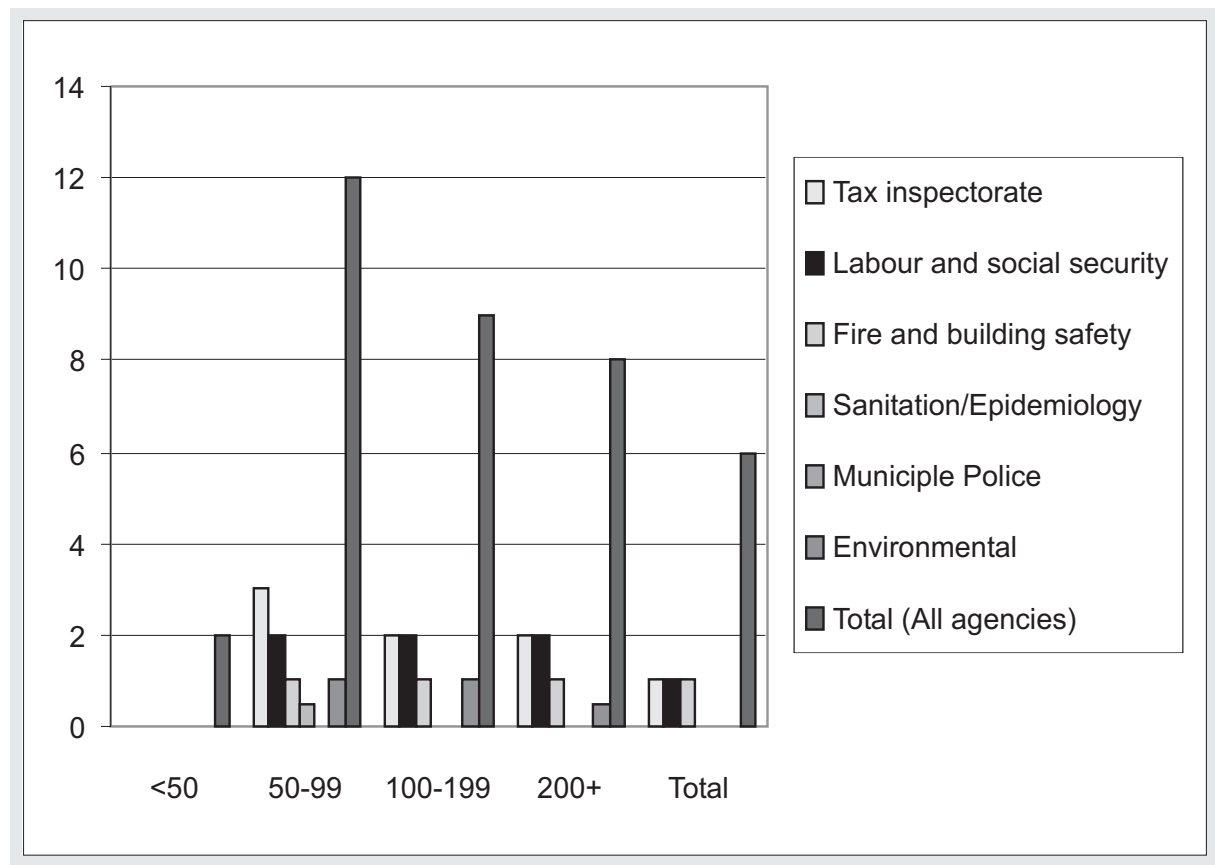




\section{The Costs of Regulation}

The impact of regulations on firms occurs through the actual (or potential) cost of the regulation to the firm. Large regulation costs provide an incentive for firms to attempt to reduce these costs. This may be through reduced firm growth to avoid costs associated with regulations that apply to firms over a certain size, substitution out of inputs (such as labour) which regulations have made more costly, and corruption of inspectors and officials that enforce regulations. Regulations can change firm behaviour even if firms do not actively try to avoid regulation. If regulations raise firm costs without increasing productivity firm efficiency will fall. Less efficient firms will be less able to compete in both the domestic and international market.

This section uses data collected by the SBP to specifically examine the actual regulation costs faced by firms. The first sub-section is similar in nature to the SBP report "Counting the Cost of Red Tape for business in South Africa." In this sub-section we examine whether regulation costs differ across size groups once firm characteristics such as age and ownership are controlled for. We also investigate what types of regulatory costs are the largest proportion of total regulation costs for firms of various sizes. In the second sub-section we investigate whether there is a relationship between firm characteristics and changes in regulation costs. Lastly we examine the strategies used by firms to avoid regulation.

\subsection{Regulatory Costs}

Although regulatory costs may differ across size categories, this may be because other firm characteristics, such as age or ownership differ. In this sub-section we investigate whether regulatory costs differ across size groups and sectors once we control for firm characteristics. This is done by using a tobit procedure to regress regulatory costs on a number of firm characteristics, such as ownership and sector, as well as firm size. If these costs do not differ by firm size, once we control for firm characteristics, this indicates that all firms regardless of size have the same level of costs. This implies that these costs are relatively larger, in terms of costs per employee or turnover, for smaller firms. Regulatory costs are classified into a number of different categories and include both the time costs to the firm and the costs of hiring outside consultants or advisors.

The estimates of regulatory costs relative to a firm employing 10-50 employees are shown in Figure 21. Of all the different types of costs there is the least variation in tax costs amongst the size groups. The tax costs of $500+$ firm is approximately 110 per cent 
(2 times) more than those for a 1-5 employee firm. A 500+ employee firm is more than 5 times larger and thus the tax cost per employee is significantly larger for smaller firms.

For total regulation costs the difference between the smallest category and the largest is about 210 per cent. This also indicates a much larger regulation cost per employee for smaller firms.

Figure 21: Regulation Costs by Firm Size. SBP Survey

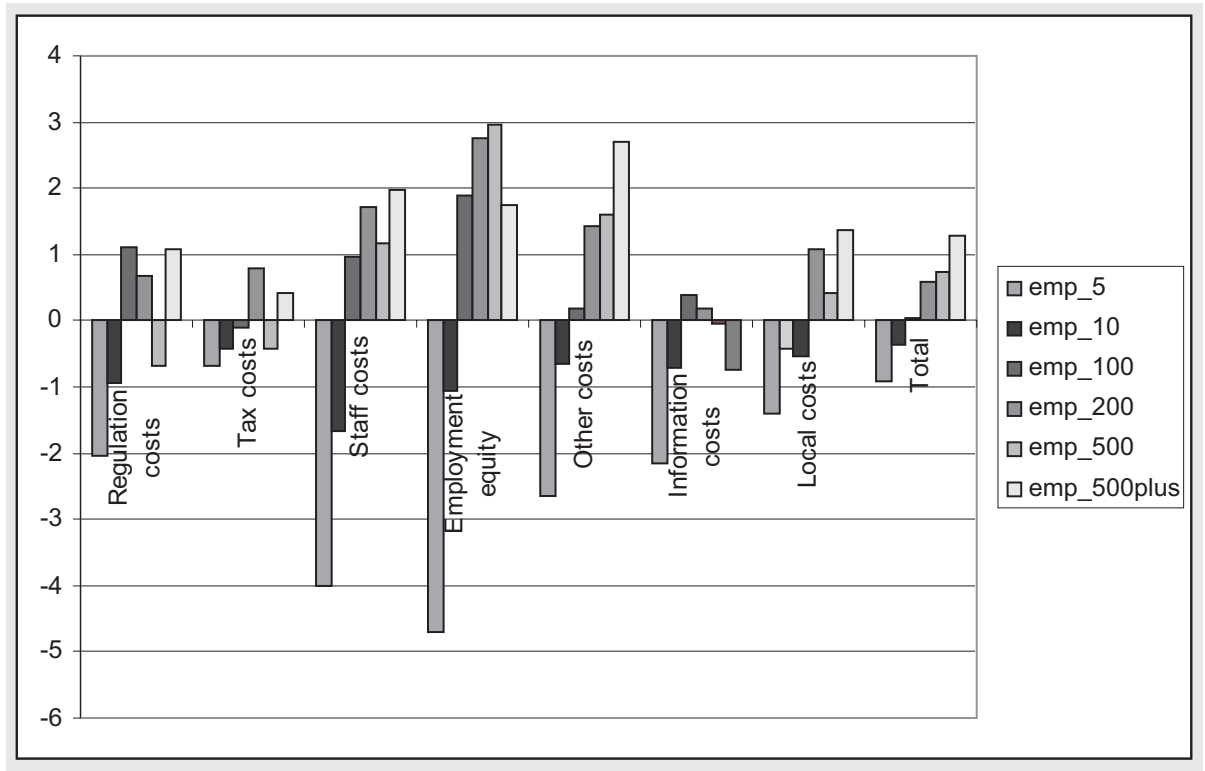

These results are similar if they are examined by turnover band - it is firms with lower turnover that have higher costs per unit of turnover. This is particularly the case in the regulation costs, staff costs, local/metro costs categories as well as for total overall costs. ${ }^{12}$ This indicates that there is a fixed cost to regulation that firms must incur regardless of their size.

Next we examine which components of total regulation costs are the largest, and how these vary across size categories. It is obvious from Figure 22 that tax costs are a larger component of total costs for smaller firms. Local authority costs are also a larger proportion of total regulation costs for smaller firms.

12 Results not presented here. 
Figure 22: The Components of Regulation Cost by Firm Size. SBP Survey

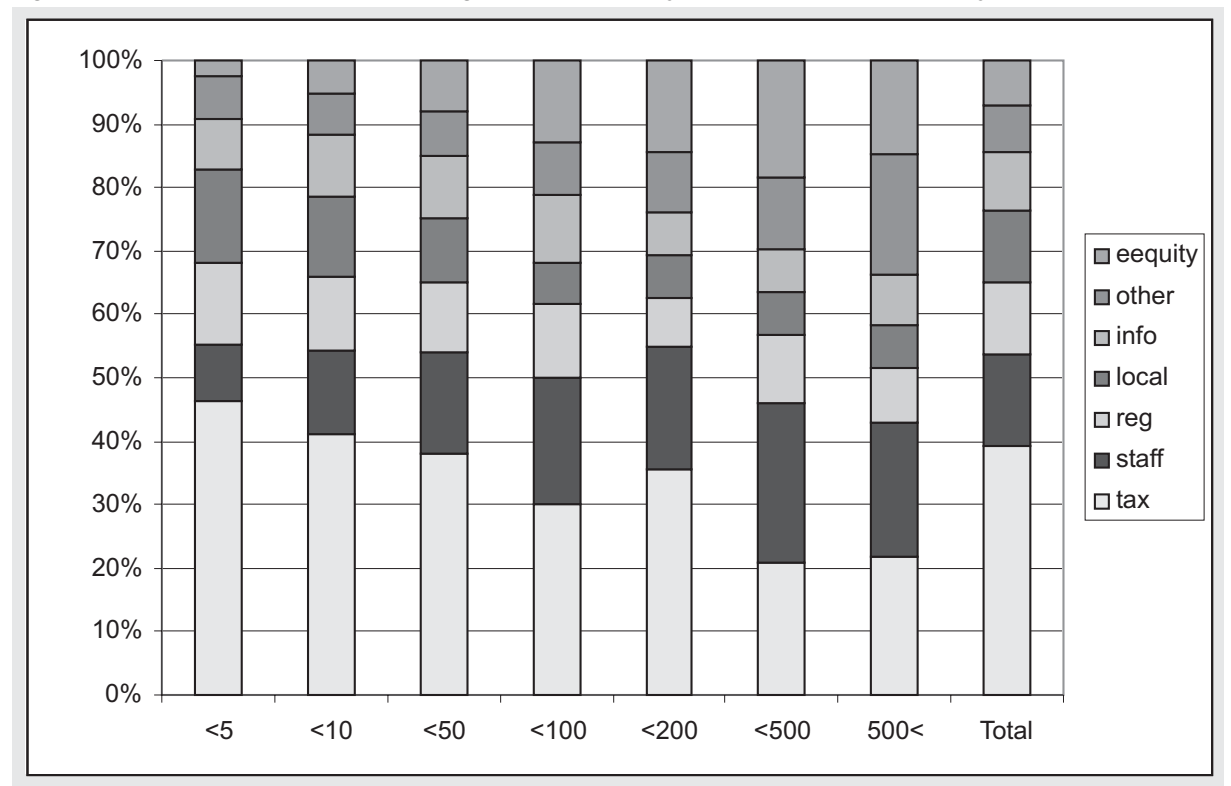

If we compare the percentage of regulatory costs between internal staff costs and the costs associated with hiring outside experts, internal staff costs are highest for all size categories. There is a slight decrease in the percentage of total costs from internal staff as size increases. As we have shown earlier, regulatory costs per employee are much larger for smaller firms. Together with these results, this indicates that staff in smaller firms spend more of their time dealing with regulation than staff in larger firms. 
Figure 23: The Proportion of Regulation Costs that are Internal Staff Costs, and External Fees, by Firm Size. SBP Survey

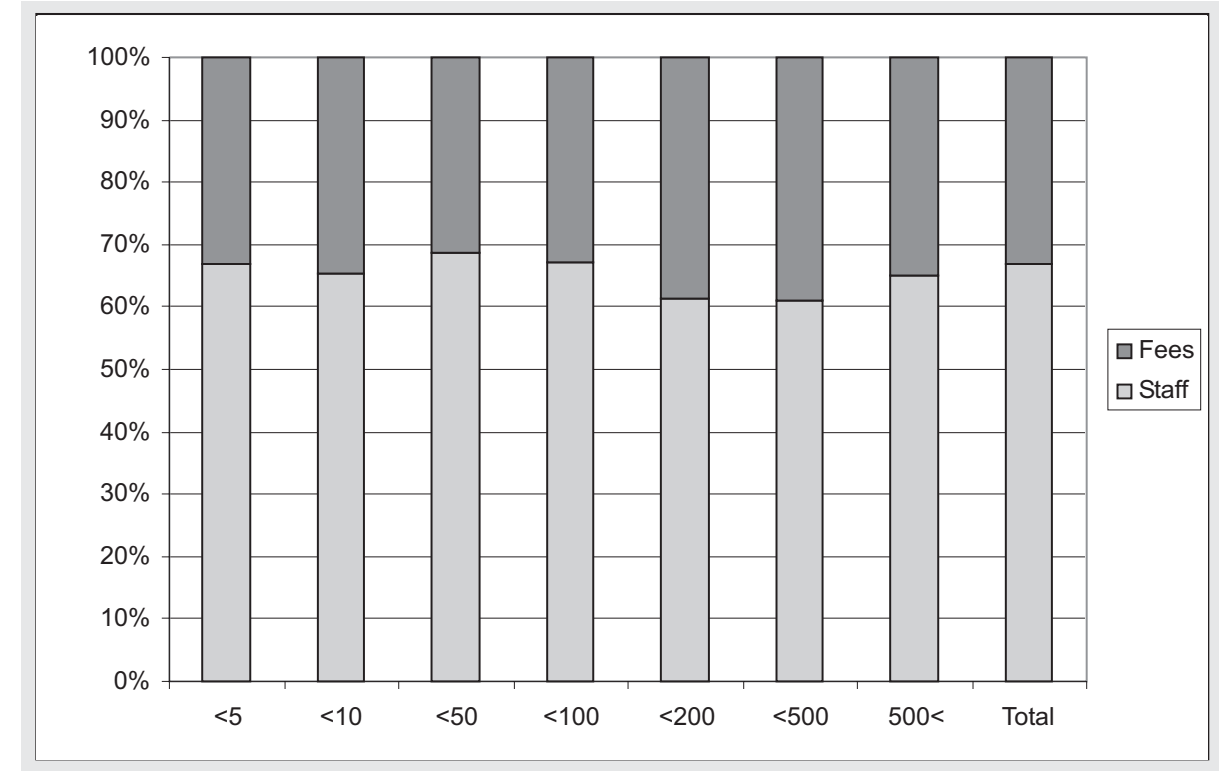

We next break down the percentage of total regulation costs arsing from internal staff costs by the various types of regulation. Tax costs are the largest component of staff time and these are a larger proportion of costs among smaller firms. This is also the case for local government costs. Staff costs, employment equity costs and other costs are a larger proportion of internal staff costs for larger firms. 
Figure 24: The Components of Regulation Cost, in Terms of Internal Staff Costs, by Firm Size. SBP Survey

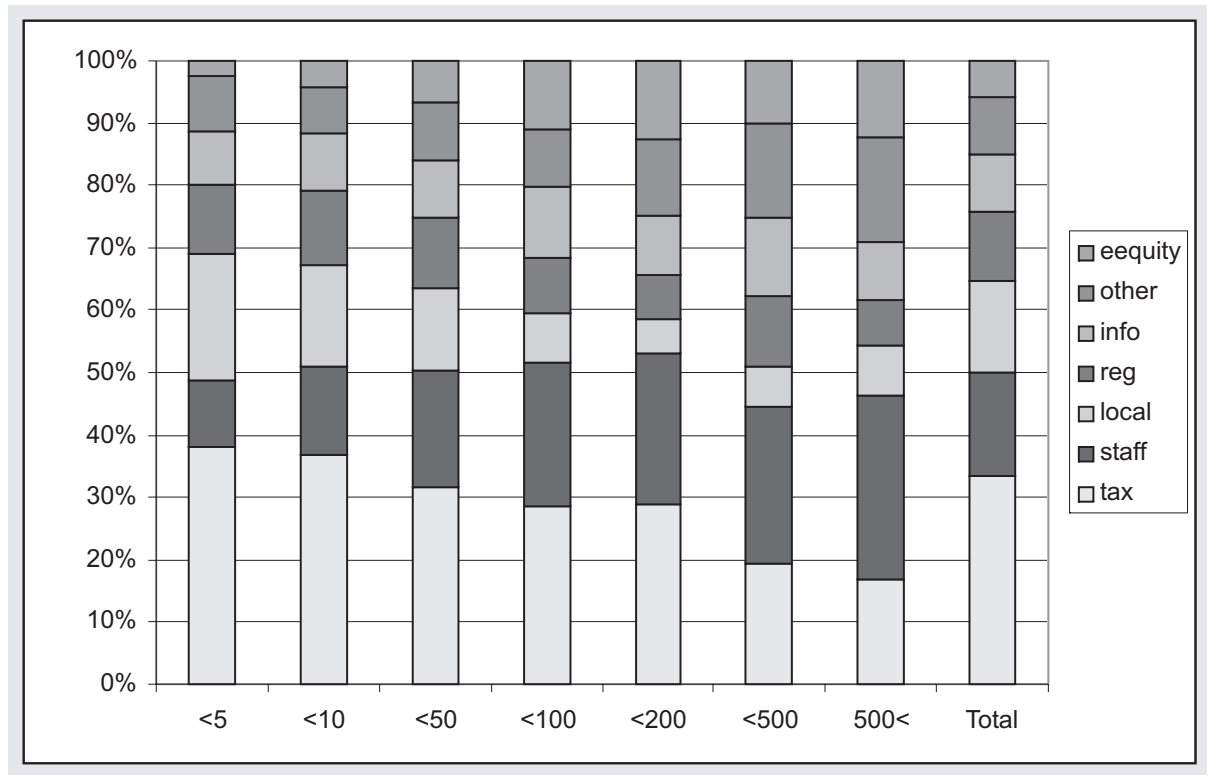

Tax costs make up 60 per cent of the total cost of outside consultants for firms with less than 5 employees. Tax costs as a proportion of costs falls as firm size increases. Local government costs also decrease as a proportion of outside consultant costs as firm size increases. Employment equity, staff and other costs all increase as a proportion of outside consultant costs as firm size increases. 
Figure 25: The Components of Regulation Cost, in Terms of External Consultant Costs, by Firm Size. SBP Survey

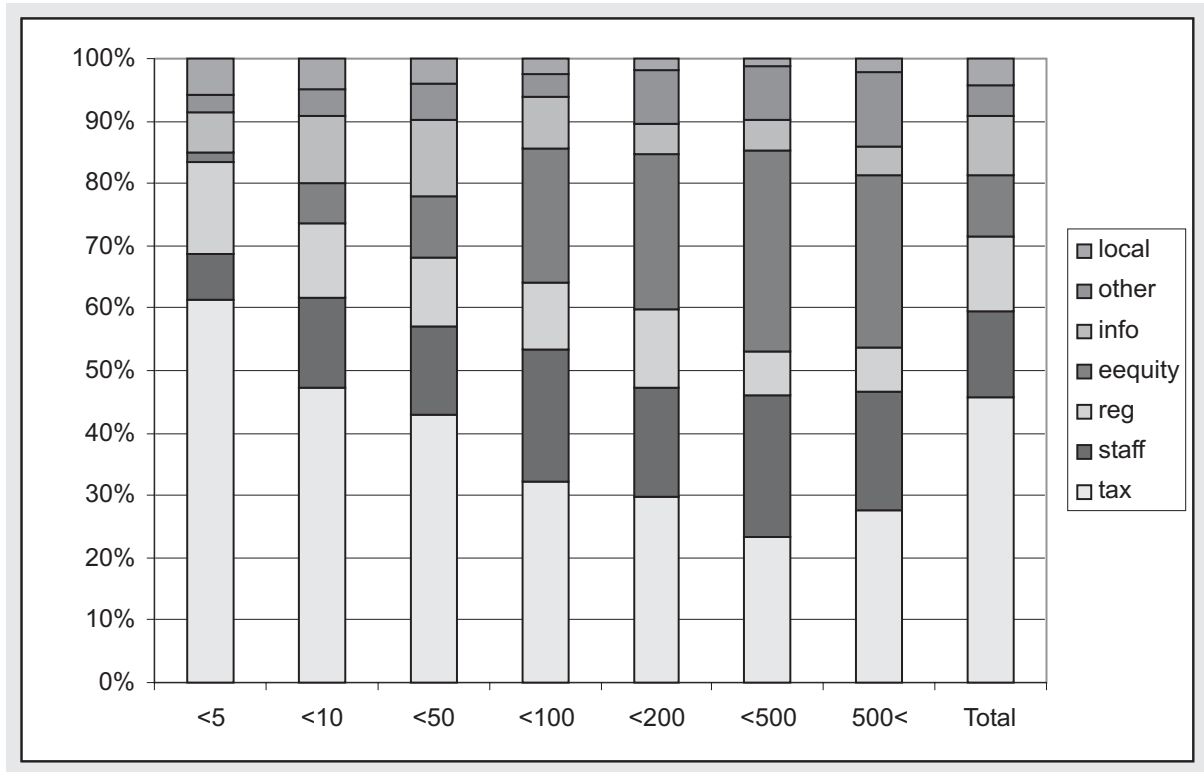

This sub-section has illustrated that regulation costs fall particularly heavily on small firms. Specifically, tax costs are most onerous for small firms. 


\subsection{What Types of Firms have Experienced Changes in Regulation Costs?}

In the SBP survey firms were asked whether regulatory costs have increased, decreased or remained the same in the past 10 years, past 2 years and whether they expect these costs to change in the future (see Table 26).

Table 26: Have Regulation Costs Changed in this Period? SBP Survey

\begin{tabular}{|l|c|c|c|c|c|c|}
\hline & \multicolumn{2}{|c|}{ Last 10 years } & \multicolumn{2}{c|}{ Last 2 years } & \multicolumn{2}{c|}{ Future } \\
\hline & Freq. & Per cent & Freq. & Per cent & Freq. & Per cent \\
\hline Increased & 1,133 & 82.28 & 1,209 & 79.12 & 1,270 & 83.01 \\
\hline $\begin{array}{l}\text { Stayed about the } \\
\text { same }\end{array}$ & 171 & 12.42 & 251 & 16.43 & 182 & 11.9 \\
\hline Decreased & 23 & 1.67 & 38 & 2.49 & 49 & 3.2 \\
\hline Don't know & 50 & 3.63 & 30 & 1.96 & 29 & 1.9 \\
\hline Total & 1,377 & 100.00 & 1,528 & 100.00 & 1,530 & 100.00 \\
\hline
\end{tabular}

Over both the last ten and two year periods approximately 80 per cent of firms report that regulation costs have increased. Less than 3 per cent of firms have experienced declining regulation costs. Firms are not optimistic about regulation costs in the future -83 per cent believe regulation costs will increase.

Over the last two years firms with higher general regulation costs, tax costs and other costs are more likely to report an increase in costs than those with lower costs in these categories. Over the last ten years it is those firms with higher general regulation costs and other costs that are more likely to report increases. ${ }^{13}$

Firms with high regulation costs and those in the transport sector are more likely to expect costs to increase in the future. Those in the agricultural sector are less likely to expect costs to increase.

13 These results are from a multinomial logit estimation where the change in the regulation costs is the dependent variable and a number of firm characteristics including current regulation costs faced are used as regressors. 


\subsection{Strategies to Avoid Regulation}

The SBP survey also asked about strategies firms use to avoid regulation. These responses are illustrated in Figure 26. A reduction in employment (either through using part-time workers or reducing employment directly) is the most common strategy after doing nothing.

\section{Figure 26: Strategies to Avoid Regulation. SBP Survey}

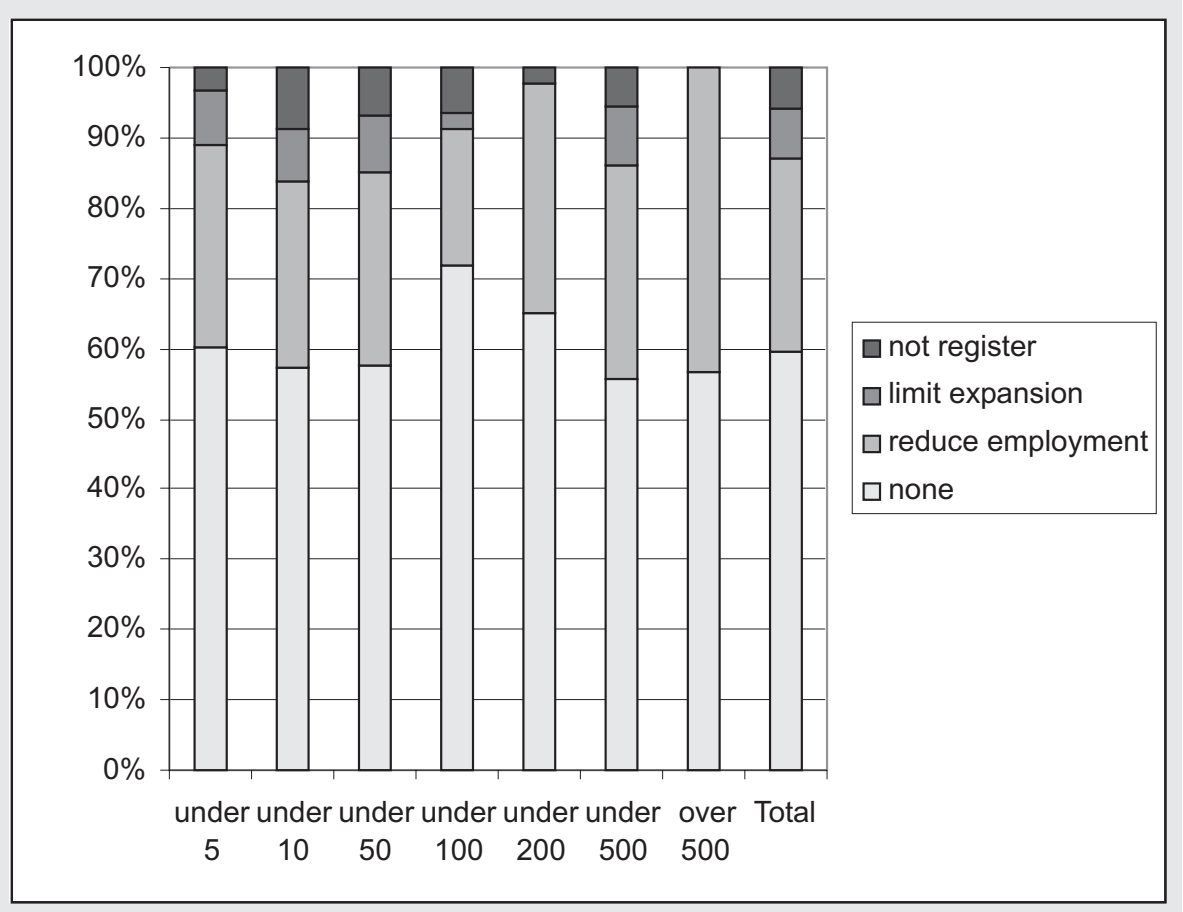

Exporters are less likely to engage in this strategy than to do nothing. Smaller firms (in terms of both employment and turnover) are significantly more likely to engage in this strategy than other firms. Also those in the tourism sector and those with high regulation and staff costs are more likely to engage in this strategy. ${ }^{14}$

14 These results come from a multinomial logit where the dependent variable is the way firms avoid regulation. 
The only significant factor influencing the choice of the limit expansion strategy is if the firm is in the trade, vehicles, hotels and restaurants sector. Firms in this sector are more likely to limit expansion than firms in other sectors. 


\section{Conclusions}

This paper has examined the impact of government regulation on firms in general, and SMMEs in particular. We began by examining how regulations compare to other potential obstacles to business. In all of the surveys examined, labour market regulation is the most often mentioned regulatory constraint to business. It ranks on a similar scale to obstacles such as the availability of skilled workers, crime and theft, and macroeconomic instability. Labour market regulations are mentioned frequently as a constraint in both the 1998 and 2002 surveys, suggesting that perceptions have not changed over the period. Tax regulations, foreign currency regulations and trade regulations are the next most commonly mentioned regulation related constraints.

We next examined the relationship between regulations and investment. Again the most commonly mentioned regulatory-related constraint to investment was labour regulations. However, those firms that cited labour regulations as a constraint to investment were more likely to invest than those firms that did not. However, there was no relationship between this constraint and the amount invested once a firm invests. A closer investigation into the type of investment found that these firms were more likely to invest in computers and plant and machinery (although this was only marginally significant). There are four ways to interpret this finding. The first is that there is no link between labour regulations and investment. The second is that firms answered this question as barriers to doing business rather than investment. The third is that the causality runs the other way - firms that are more likely to invest are more likely to cite labour regulations as a constraint to investment. It would then be that only those firms that invest feel constrained by the labour regulations. The fourth interpretation is that firms that feel constrained by the labour regulations are actually investing to substitute capital for labour. Further research is required to investigate which of these interpretations may be correct.

The fourth section examined the relationship between labour regulations and employment. In this section we found that labour regulations are regarded by many firms as a constraint to expanding full-time employment and that the impact of labour regulations falls heavily on small firms and the unskilled. Labour regulations are the most common reason given for a decline in unskilled employment among firms with less than 50 employees. In larger firms, and among other skills categories, changes in market outlook are the most common reason given for a decline in employment. This suggests that the negative consequences of the labour regulations are often borne by the unskilled, particularly those that work (or used to work) in smaller firms. 
There is also evidence that firms that find the labour regulations onerous experienced lower growth in employment. This is particularly the case for smaller firms. A firm with 50 employees affected by the LRA grew by 25 per cent less over four years, than a firm unaffected by these regulations. This is in contrast to a 1000 employee firm where the gap is 18 per cent. Between 1994 and 1998 the typical 50 employee firm unaffected by the LRA would have grown from 50 employees to 76 employees. An identical firm affected by the LRA would have grown to only 64 employees. In the context of widespread unemployment in South Africa this suggests that on a national scale labour regulations constrain employment creation. These results are for a sample of firms that survived over the four years. If labour regulations caused firms to exit, these reported results would underestimate the effect. Similarly, if labour regulations caused firms to enter, then these results overestimate the impact of labour regulations on firm growth and employment.

The parts of the regulations that firms find most onerous are those that relate to firing procedures. The next most onerous parts are those related to hiring. This suggests that part of the reason why firms dislike the regulations is the time and administrative burden they impose. However, this may also indicate that these labour regulations make hiring and firing more difficult, and thus costly, for firms.

Firms do not perceive that labour regulations have had much benefit. More firms view labour market regulations as costs rather than benefits. However, a quarter of firms felt that labour relations improved due to the labour regulations. Only 9 per cent felt that the labour regulations lead to an improvement in labour productivity.

Section 5 examined the impact of trade regulations on small firms. Many small firms do not participate in the international market through imports and/or exports. Part of the reason for this may be that, due to their size, the costs of entry into this market are prohibitive. In 1998, over 60 per cent of firms reported that import tariffs were too high. Smaller firms were more likely than larger firms to report tariffs as too high. They were also less likely to say that tariff reductions had lowered their local market share. The costs and delays associated with clearing customs were more likely to be an obstacle for large firms - this is because larger firms are more likely to participate in the international market. A reduction in costs and a simplification of procedures may enable more small firms to enter the market.

Government regulations associated with the licences and permits required to start, expand or continue operations were examined in Section 6. It takes a typical firm a shorter time to obtain a construction, import or operating licence than to get a telephone, electrical or water connection. Eighty-five per cent of firms thought that the number of licences 
required to continue operation was reasonable. A similar percentage thought the number for starting a business was also reasonable. Firms felt that the time costs were more onerous than the money costs. This suggests that simplification of licensing procedures would be beneficial to firms.

Section 7 examined other aspects of regulation not covered in the previous sections. The first sub-section examined the costs of hiring expatriates, as this may be a possible shortterm solution to the lack of skilled labour mentioned by many firms. Smaller firms are less likely to hire expatriate workers, but if they do, these form a larger proportion of the workforce. The median cost to a firm with less than 100 employees to hire an expatriate worker is more than double the cost to a firm with more than 200 employees. This explains why smaller firms are less likely to hire expatriates than larger firms. A reduction in the costs to obtain an expatriate visa should increase the probability of smaller firms hiring skilled expatriate staff.

Section 7 also examined the predictability and consistency of regulation interpretation. Approximately half the firms thought that regulation interpretation was consistent. This means that 50 per cent of firms find regulation interpretation unpredictable - a very large proportion. Firms with less than 50 employees and those with more than 200 employees are the most likely to say that regulatory interpretation is not predictable. Unpredictability is likely to have serious costs to firms and consequently to the economy. It makes it more difficult to plan for the future and consequently would be detrimental to investment and growth. This sub-section also examined which departments are perceived to have the most unwieldy procedures. The Department of Labour and the Local Metropolitan Authority were the departments mentioned most often. Individuals in these departments were also most likely to ask for bribes, although bribes were not common within the sample. Resorting to bribes is one way that firms may respond to regulations that impose large costs on them.

In Section 7, we also examined the time spent in meetings related to regulations. There is a large jump in the time spent between firms with less than 50 employees and those in the 50-99 employees size group. The time spent in meetings then decreases with firm size. This finding suggests that there is a large cost, in terms of time, associated with a move from below to above 50 employees. This is likely to act as a disincentive for smaller firms to grow. Again, these findings suggest that it is the time and administrative burden associated with regulations, rather than the direct monetary cost, that firms find most onerous. 
Section 8 specifically examined the costs associated with regulation. These costs are twofold: first, the cost of staff time spent dealing with regulations; second, the costs of paying for outside consultants. Across all size groups the staff costs are greater than the outside consultant costs. In this section we have shown that the costs of regulation fall disproportionately on smaller firms. This is particularly the case for tax costs. Smaller firms have a similar level of tax costs to larger firms, and these costs comprise a larger proportion of total regulatory costs. This means that tax costs per employee are much higher for smaller firms. This is not only the case for tax costs but also applies to the costs associated with complying with local authority regulations and regulatory costs in general. Approximately 80 per cent of firms report that regulatory costs have increased in the last two years. A similar proportion expects regulatory costs to rise in the future.

What do these results mean for South African SMMEs? Regulations affect firms through the costs they impose. If regulations are costly for firms to comply with, and the benefits from complying are small, an incentive exists for firms to attempt to avoid these regulations. There are a number of ways that this may reflect in firm behaviour. The first is the disincentive effect on firm growth, in general, and the use of the factor affected by the regulation in particular. The second related outcome is substitution out of the factor made more costly by regulation. The third outcome is avoidance of the regulation, through say the under-reporting of revenue or size, payment of bribes to regulators or inspectors, or failure to register the company. The last outcome is a reduction in efficiency if regulation imposes costs and little benefits. If these costs fall disproportionately on certain firms, such as smaller firms or exporting firms then these firms will be disadvantaged when competing against firms which bear a smaller regulatory burden.

This survey has highlighted a number of regulations whose costs do fall disproportionately on certain firms and types of inputs, including types of workers. It has also highlighted ways that firms respond to these regulations.

Labour regulations are the most commonly mentioned regulatory constraint to growth. Exporting firms and those with a higher proportion of unskilled workers are more likely to mention labour regulations as a constraint than other types of firms. The response to labour market regulations differs by firm size. Larger firms are more likely to outsource or sub-contract whilst smaller firms are more likely to do nothing. It is unlikely that this is because they are not constrained by these regulations but rather because they lack the resources to respond. This conclusion is strengthened when only the firms that reduced employment are examined. Particularly among the smaller firms, the major reason given for a reduction in the number of unskilled workers is labour market regulations. It is also confirmed if the effect of these regulations on firm growth is examined. There is evidence 
that these regulations constrain firm growth - those firms that claim to be affected by labour regulations grow employment slower than unaffected firms - and that they have a larger effect on the growth of smaller firms. In addition to substituting away from unskilled workers as a result of labour regulations, there is some indication that firms may also be substituting capital for labour as a response to these regulations.

Firms perceive that the hiring and firing procedures of the regulations are the most onerous. The parts of the regulations that deal with working time, leave provisions, collective action and affirmative action are perceived by fewer firms as serious obstacles.

The second area where regulations disadvantage smaller firms is tax. The survey results suggest that there is a similar cost to complying with tax regulations regardless of firm size, and therefore in terms of the cost per worker, tax costs are much larger for smaller firms. These tax costs also comprise a larger proportion of total regulation costs for smaller firms.

Trade regulations are another area where changes may benefit small firms more than large firms. Small firms are more likely to report that import tariffs are too high and less likely to report that they have lost market share to foreign competitors due to tariff reforms. Smaller firms are also less likely to be in the international market, either as exporters or importers. This suggests that the costs of importing and exporting are relatively larger for smaller firms, and that a reduction in these costs may encourage these firms to enter the international market. This is desirable because, among other benefits, it increases the size of the potential market which may allow for economies of scale and firm growth; acts as a channel for technology transfer which may improve efficiency and product quality; and diversifies both the revenue stream and supplier base which may make the firm better able to survive macro-economic shocks.

A common finding throughout this paper is that it is the time cost of regulations that are more onerous than the direct monetary cost. Although monetary costs are important, the data presented here suggest that it is administrative costs of complying with the regulations that firms find more costly.

The paper has also highlighted a number of ways that firms respond to regulations. There is evidence that burdensome regulations provide a disincentive for firms to grow and may actually result in a decrease in employment. Data from the SBP survey indicates that the most common strategy to avoid regulations, after doing nothing, is for firms to limit 
employment. ${ }^{15}$ There is also evidence that firms, particularly smaller firms, affected by the labour regulations grow at a slower rate than unaffected firms. Among workers the most likely group to be dismissed as a consequence of these regulations are the unskilled in smaller firms.

The second way that firms may respond is by substituting out of the factor, market or product for which the regulations are a burden. There is not much evidence that this is happening in terms of labour - a reduction in size, or limiting growth are more common strategies. There is evidence that smaller firms are less likely to participate in international markets and this may in part be a consequence of trade regulations that are relatively more costly for smaller firms.

The third potential outcome of burdensome regulations is a reduction in the efficiency of firms. Firm efficiency will be reduced if regulations raise costs without increasing output. Productivity is key to compete and expand in both international and domestic markets. Although this paper has not examined the issue of productivity in depth, it has highlighted how the costs of some regulations fall heavily on the smaller firms. These smaller firms will have to be more efficient to compete with larger firms where the relative regulatory burden may be smaller.

This paper has shown that government regulations can and do have unintended consequences as well as costs for firms. In conclusion we highlight some areas where relatively small policy changes may have large benefits for efficiency, firm growth and employment, particularly for SMMEs. The first is to simplify regulations and the time and administrative burden of complying with these regulations. Initiatives such as SARS eFiling system provide a good example of how this may be done. The second change would be to relax the hiring and firing procedures in the labour regulations. This could be coupled with an exemption from some of the more onerous parts of the regulations for smaller firms, for example those that employ less than 200 people. As this paper has shown, the unskilled in smaller firms are the most likely to lose their jobs as a result of these regulations. Loosening the regulations in these firms should encourage them to hire more unskilled workers. The last recommendation is to continue tariff liberalisation.

15 How does one reconcile the two, at first glance anomalous findings, that regulatory costs are larger per worker among smaller firms, and that firms respond to regulation by limiting employment? A simple, but wrong, conclusion would be to suggest that firms should grow employment so as to reduce the regulatory costs per employee (the average regulatory costs). However, this ignores the trade-off firms make between the marginal cost of hiring a worker (which in this case includes their wage, other benefits, as well as the additional regulatory costs) and the marginal product, or benefits provided by the worker. It also makes the mistake that the marginal regulatory costs of a worker are zero or negative. They are not - they are simply less than the average regulatory costs. This is what brings down the regulatory costs per worker. 
Tariffs penalise smaller firms more than large firms, and even among large firms, the majority thought tariffs were too high. These policies should increase firm-level efficiency making South African firms better able to compete and grow in a globalising economy and consequently lead to higher employment. 


\section{References}

Fedderke J.W., Kularatne, C., and Mariotti, M., 2003, "Mark-up Pricing in South African Industry." Mimeo.

Rankin, N., 2002, "The Export Behaviour of South African Firms" Trade and Industrial Policies Strategy (TIPS) Working Paper.

Tybout, J., 2001, "Manufacturing Firms in Developing Countries: How Well Do They Do, and Why?" Journal of Economic Literature, Vol. 38, No. 1, pp. 11-44.

Tybout, J., 2003, "Plant- and Firm-level Evidence on the 'New' Trade Theories" in E. Kwan Choi and James Harrigan, ed., Handbook of International Trade, Oxford: BasilBlackwell, 2003.

SBP, 2005, Counting the Cost of Red Tape for business in South Africa. Johannesburg, South Africa. 